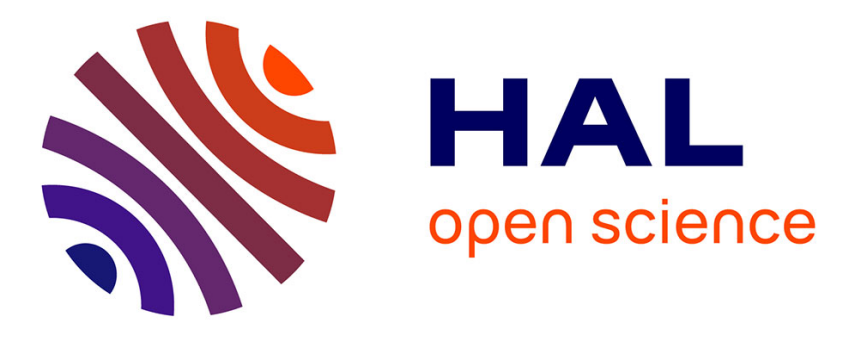

\title{
Controlling Plasma Stability of Hydroxamic Acids: A MedChem Toolbox
}

Paul Hermant, Damien Bosc, Catherine Piveteau, Ronan Gealageas, Baovy

Lam, Cyril Ronco, Matthieu Roignant, Hasina Tolojanahary, Ludovic Jean, Pierre-Yves Renard, et al.

\section{To cite this version:}

Paul Hermant, Damien Bosc, Catherine Piveteau, Ronan Gealageas, Baovy Lam, et al.. Controlling Plasma Stability of Hydroxamic Acids: A MedChem Toolbox. Journal of Medicinal Chemistry, 2017, 60 (21), pp.9067-9089. 10.1021/acs.jmedchem.7b01444 . hal-03054238

\section{HAL Id: hal-03054238 https://hal.science/hal-03054238}

Submitted on 11 Dec 2020

HAL is a multi-disciplinary open access archive for the deposit and dissemination of scientific research documents, whether they are published or not. The documents may come from teaching and research institutions in France or abroad, or from public or private research centers.
L'archive ouverte pluridisciplinaire HAL, est destinée au dépôt et à la diffusion de documents scientifiques de niveau recherche, publiés ou non, émanant des établissements d'enseignement et de recherche français ou étrangers, des laboratoires publics ou privés. 


\title{
Controlling Plasma Stability of Hydroxamic Acids: A MedChem Toolbox.
}

\author{
Paul Hermant, ${ }^{\# 1}$ Damien Bosc, ${ }^{\# 1}$ Catherine Piveteau, ${ }^{\# 1}$ Ronan Gealageas, ${ }^{1}$ BaoVy \\ Lam, ${ }^{1}$ Cyril Ronco, ${ }^{1}$ Matthieu Roignant, ${ }^{1}$ Hasina Tolojanahary, ${ }^{1}$ Ludovic Jean, ${ }^{2}$ Pierre- \\ Yves Renard, ${ }^{2}$ Mohamed Lemdani, ${ }^{3}$ Marilyne Bourotte, ${ }^{1}$ Adrien Herledan, ${ }^{1}$ Corentin \\ Bedart,${ }^{1}$ Alexandre Biela, ${ }^{1}$ Florence Leroux,${ }^{1}$ Benoit Deprez, ${ }^{1}$ Rebecca Deprez-Poulain $*, 1,4$
}

1. Univ. Lille, Inserm, Institut Pasteur de Lille, U1177 - Drugs and Molecules for Living Systems, F-59000 Lille, France; 2. Normandie Université, COBRA, UMR 6014 \& FR 3038, Université de Rouen, INSA Rouen, CNRS, F-76821 Mont-Saint-Aignan Cedex, France.; 3 Univ. Lille. EA 2694 - Santé publique : épidémiologie et qualité des soins. F-59000 Lille. France. Institut 4. Institut Universitaire de France, F- 75231, Paris, France.

\begin{abstract}
Hydroxamic acids are outstanding zinc chelating groups that can be used to design potent and selective metalloenzyme inhibitors in various therapeutic areas. Some hydroxamic acids display a high plasma clearance resulting in poor in vivo activity, though they may be very potent compounds in vitro. We designed a 57-member library of hydroxamic acids to explore the structure-plasma stability relationships in these series and identify both which enzyme(s) and which pharmacophores are critical for plasma stability. Arylesterases and carboxylesterases were identified as the main metabolic enzymes for hydroxamic acids. Finally, we suggest structural features to be introduced or removed to improve stability. This work provides thus the first medicinal chemistry toolbox (experimental procedures and structural guidance) to assess and control the plasma stability of hydroxamic acids and realize their full potential as in vivo pharmacological probes and therapeutic agents. This study is particularly relevant to preclinical development as it allows to obtain compounds equally stable in human and rodent models.
\end{abstract}




\section{Introduction}

The hydroxamic acid function is a strong zinc chelating group. It can be used to design potent and selective metalloenzymes inhibitors that can serve both as biological probes ${ }^{1}$ and leads. Hydroxamic acids can also be used as bioisosters of carboxylic acid thanks to their weak acid properties. ${ }^{2}$ In the field of infectious diseases, several hydroxamic acid series have been reported as antibacterials : inhibitors of peptide deformylase (PDF) ${ }^{3}$, inhibitors of the neurotoxin A metalloprotease of bacterium Clostridium botulinum (BoNTA) ${ }^{4}$, or inhibitors of UDP-3-O-(R-3-hydroxymyristoyl)- $N$-acetylglucosamine deacetylase (LpxC) of gram-negative bacteria. ${ }^{5}$ Antivirals targeting HCV replication via a yet unknown mechanism, ${ }^{6} \mathrm{HIV}$ integrase inhibitors, ${ }^{7}$ or inhibitors of metalloproteases of the Plasmodium falciparum parasite, ${ }^{8}$ have also been disclosed. Recently, inhibitors of the essential nematode-specific metalloprotease DPY31 were discovered via combined in silico and experimental methods. ${ }^{9}$ Several groups have explored the use of hydroxamic acids in other therapeutic areas inhibitors of glutamate carboxypeptidase II (GCPII) in neuropathic pain; ${ }^{10}$ inhibitors of Insulin-Degrading Enzyme in type-2 diabetes ${ }^{11}$, inhibitors of Matrix metalloprotease (MMP) in fibrinolysis control ${ }^{12}$. In osteoarthritis, matrix-metalloproteinase ${ }^{13}$ or aggrecanase inhibitors ${ }^{14}$ have been proposed, while inhibitors of Tumor Necrosis Factor Converting Enzyme (TACE, ADAM17) were designed for autoimmune diseases such as psoriasis or Crohn's disease. ${ }^{15-16}$ In the area of cancer, several hydroxamic acids have been designed to inhibit various proteases such as the sheddase of HER-2. ${ }^{17}$ Importantly, with the growing interest in epigenetics, many teams explored the possibility to inhibit other zinc hydrolases, like histone deacetylases (HDACs). Several hydroxamic acid inhibitors of these targets have already been approved: vorinostat, and belinostat for T-cell lymphoma and recently panobinostat for multiple myeloma (Figure 1). Many other hydroxamic acids are currently following on these first clinical successes, not only in cancer, but also in several other therapeutic areas. ${ }^{18-19}$ 
<smiles>O=C(CCCCCCC(=O)Nc1ccccc1)NO</smiles>

vorinostat (SAHA)

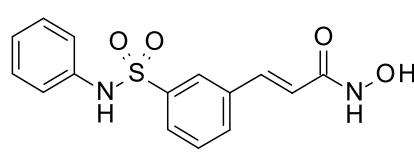

belinostat

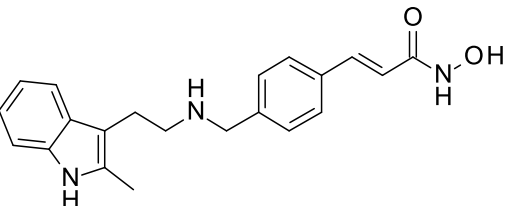

panobinostat

Figure 1: Marketed hydroxamic acid drugs.

The hydroxamic acid function undergoes phase I and phase II metabolism: it is mainly hydrolysed to the corresponding carboxylic acid, ${ }^{20}$ but also it can be reduced to the corresponding amide ${ }^{21}$, O-glucuronylated or O-sulfated ${ }^{22}$. The carboxylic acid is usually much less active on the target and possesses different physical-chemical and permeability properties, than its hydroxamic acid analogue. ${ }^{23}$ Depending on the fragility of the hydroxamic acid function, and the substituents in $\alpha$ - or $\beta$-position, ${ }^{24}$ metabolism is driven towards the production of carboxylic acid, or the production of O-glucuronides. For example, the main metabolite of belinostat is the glucuronide form. ${ }^{25}$

We and other groups have tried to improve the pharmacokinetics properties of hydroxamic acids thanks to chemical modulation. ${ }^{8,26} \mathrm{We}$ have published a preliminary study of in vitro structure-plasma stability relationships (SPSR) of such compounds. ${ }^{24}$ Here, we show that susceptibility to the esterase activity in plasma is a critical driver of the stability of hydroxamic acids.

Although often overlooked, esterases are worth considering in medicinal chemistry as they are involved in the metabolism of $10 \%$ of drugs. ${ }^{27}$ Also, in specific situations, esterase activity can be used to release a parent drug from the ester prodrug (e.g. angiotensin-converting enzyme inhibitors, oseltamivir, tenofovir disoproxil) $)^{28}$ or to inactivate rapidly a compound like in the soft-drug strategy ${ }^{29}\left(\right.$ ROCK inhibitors $\left.{ }^{30}\right)$. Esterases can be sorted in two main types. Type A (arylesterases) includes paraoxonase-1 (PON-1) and other aryl esterase activities. Type B (serine esterases) includes acetyl- and butyl-cholinesterases (AchE and BuChE) as well as carboxylesterases (CES1 and 2) (Table 1). Along with these main enzymes, other esterases like arylacetamide deacetylase and acylpeptide hydrolase have been described.$^{27}$ Last but not least, 
albumin, which is the most abundant protein in plasma, possesses a pseudo-esterase activity resulting in acylation of several of its nucleophilic residues such as Tyr411. ${ }^{31}$

Table 1:Esterases classification. ${ }^{\mathrm{a}}$

\begin{tabular}{|c|c|c|c|c|c|c|}
\hline \multirow{3}{*}{ 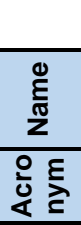 } & \multicolumn{2}{|c|}{ Type A esterases } & \multicolumn{3}{|c|}{ Type B esterases } & \multirow{3}{*}{$\begin{array}{c}\text { Others } \\
\text { Albumine } \\
\text { SA }\end{array}$} \\
\hline & Paraoxonase & $\begin{array}{l}\text { Other aryl } \\
\text { esterase } \\
\text { activities }\end{array}$ & \multicolumn{2}{|c|}{ Cholinesterases } & Carboxylesterases & \\
\hline & PON1 & $\operatorname{ArE}$ & AChE & BuChE & CES & \\
\hline 茟 & 3.1.8.1 & 3.1.1.2 & 3.1.1.7 & 3.1.1.8 & 3.1.1.1 & 6.1 .1 .16 \\
\hline 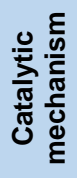 & $\begin{array}{l}\text { Catalytic dyad His/His } \\
\mathrm{Ca}^{2+} \text { activated }\end{array}$ & undefined & \multicolumn{3}{|c|}{$\begin{array}{l}\text { Serine catalyzed } \\
\text { Catalytic triad Ser, Glu, His }\end{array}$} & $\begin{array}{l}\text { Irreversible } \\
\text { acetylation of } \\
\text { Tyr411 and } \\
\text { other } \\
\text { residues }\end{array}$ \\
\hline \multicolumn{7}{|c|}{ Substrates \& Inhibitors } \\
\hline 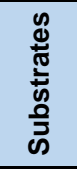 & $\begin{array}{c}\mathrm{RCOOAr} \\
\mathrm{R}_{1} \mathrm{O}\left(\mathrm{R}_{2} \mathrm{O}\right)-\mathrm{PO}-\mathrm{OAr}\end{array}$ & RCOOPh & $\mathrm{CH}_{3} \mathrm{COOR}$ & $\begin{array}{l}\text { BuCOOR, } \\
\text { AlkCOOR }\end{array}$ & $\begin{array}{l}\text { numerous prodrugs } \\
\mathrm{R}_{1} \mathrm{COOR}_{2}\end{array}$ & $\mathrm{CH}_{3} \mathrm{COOR}$ \\
\hline 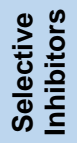 & EDTA & DTNB & $\begin{array}{l}\text { PMSF; tacrine; } \\
\text { huprine }\end{array}$ & $\begin{array}{l}\text { PMSF; tacrine; } \\
\text { profenamine }\end{array}$ & PMSF; BNPP & undefined \\
\hline
\end{tabular}

Phenylmethylsulfonyl fluoride; BNPP: bis-para-nitrophenylphosphate.

These enzymes display different substrate specificities (Table 1). Using a histidine dyad, ${ }^{32}$ PON-1 hydrolyzes both arylesters and phosphotriesters and is inhibited by chelating agents such as EDTA. On the opposite, other plasma arylesterase activity do not have the ability to cleave the phosphotriesters ${ }^{33}$ and are inhibited by 5,5'-dithiobis(2-nitrobenzoic acid) (DTNB). ${ }^{34}$ BuChE displays a larger hydrophobic pocket that accounts for its less stringent substrate specificity over AChE. Both $\mathrm{AChE}$ and $\mathrm{BuChE}$ are inhibited by phenylmethylsulfonyl fluoride (PMSF), an irreversible inhibitor of serine proteases and tacrine, a prototypal cholinesterase inhibitor, or by specific non-covalent inhibitors (huprines ${ }^{35}$ and profenamine respectively). CES1 and 2 are both inhibited by PMSF and bis-(4-nitrophenyl)-phosphate (BNPP) but CES1 recognizes substrates with either small or large acyl groups. ${ }^{36}$ 
Importantly, tissue distribution of these enzymes differs among species, ${ }^{37}$ in particular in plasma. ${ }^{38-39}$ While CES are the major esterases in rodent plasma, they are absent in human plasma. ${ }^{40}$ On the contrary, AChE and BuChE are present at lower concentrations in rodent plasma. The major esterase in human plasma is $\mathrm{BuChE}$ while $\mathrm{AChE}$ is only present in trace amounts. ${ }^{41}$ Along with the plasma isoform of AChE, the E isoform of AChE (also called $\mathrm{H}$ for hydrophobic) is found in erythrocytes. ${ }^{42}$ Interestingly, PON-1 which is associated to HDL, displays a high polymorphism that impacts its expression and activity. ${ }^{32,43}$ Moreover, along with a presence in the serum, some esterases can be found in both liver and intestine. Importantly, CES1 is largely expressed in liver microsomes while CES2 is expressed in intestine microsomes, ${ }^{40}$ where they participate actively in drug metabolism. ${ }^{28}$ For these enzymes also, species differences in distribution have been reported. ${ }^{39,40}$

Compounds that are unstable in plasma tend to display a high clearance, resulting in poor oral bioavailability and thus poor or undetectable activity, though they may be very potent compounds in vitro. The utility of such compounds as tools to probe in vivo pharmacokinetic/pharmacodynamic relationships in animal disease models in early drugdiscovery is thus compromised. ${ }^{44}$

The goal of this study is to establish Structure Plasma Stability Relationships (SPSR), identify enzymes at play in hydrolysis, and provide structural guidance to chemists in the design of hydroxamic acids that show sufficient stability in rodents. Obtaining hydroxamates that are equally stable in rodent and human is key to engage the target in preclinical disease models at the lowest dose, generate animal proof-of-principle and make a first assessment of the safety window. This is of particular importance as rodent plasma is much more aggressive to hydroxamic acids than human plasma, a cause of poor systemic exposure in preclinical models. A common practice in drug discovery is to optimize compounds potency on both a human target and its rodent ortholog, as well as stability on human and rodent liver microsomes to allow for 
a proof of concept in animal models. Optimization of rodent plasma stability is of similar importance for the particular case of hydroxamic acids, even if the lead compound is already stable in human plasma.

In order to provide medicinal chemists with tractable information for improving stability of hydroxamic acids, we report here a set of protocols and results (the toolbox) that comprises tools to assess plasma stability of hydroxamic acids, structure-plasma stability relationships and dashboards for the identification of involved esterases.

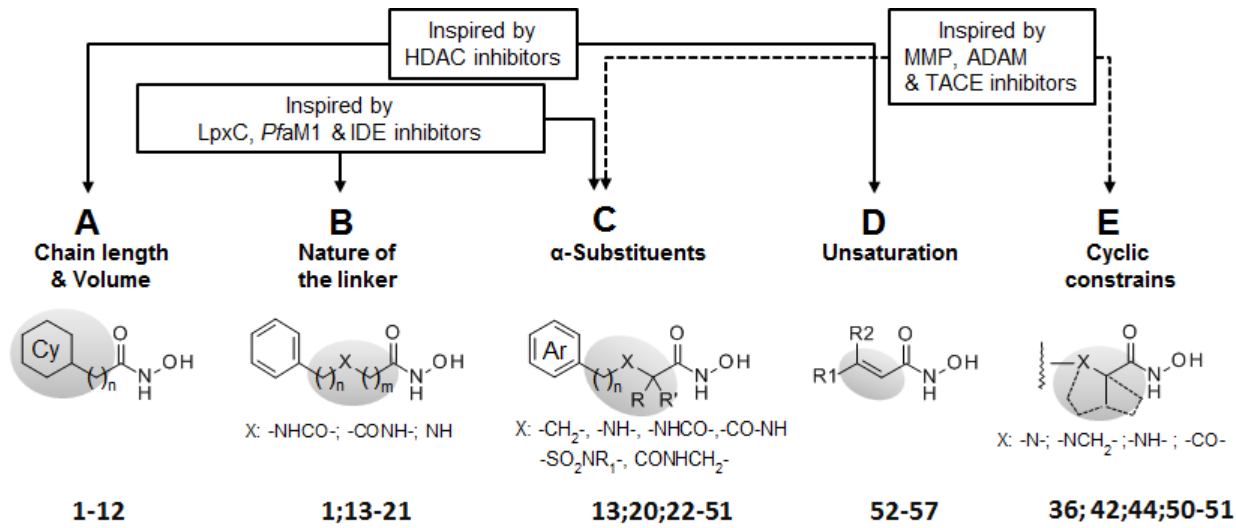

Figure 2: Hydroxamic acid library design. ${ }^{a}$

${ }^{\mathrm{a}} \mathrm{n}=0-6 ; \mathrm{m}=1-3$; In gray highlight: diversity within each hydroxamic acid library subset; $\mathrm{Cy}=\mathrm{Bz}$ or $\mathrm{cHx}$ or adamantyl; $\mathrm{Ar}=\mathrm{Bz}$, p-fluorobenzyl, 4-pyridinyl, biphenyl, heteroaryl.

\section{Results}

\section{Library Design.}

To maximize the relevance of our study for medicinal chemists, we selected substructures found in a wide range of biologically active hydroxamic acids. The resulting 57member library inspired from inhibitors of several classes of $\mathrm{Zn}$ metallohydrolases, allows in turn to explore different esterase pockets. We study the impact of chain length and volume (112, Figure 2A), nature of the linker $(\mathbf{1 , 1 3 - 2 1}$, Figure $2 \mathrm{~B})$; $\alpha$-substituents $(\mathbf{1 3 , 2 0 , 2 2 - 5 1}$, Figure 2C); unsaturation (52-57, Figure 2D) and cyclic constraints $(\mathbf{3 6 , 4 2 , 4 4 , 5 0 - 5 1 , ~ F i g u r e ~ 2 E ) , ~ a n d ~}$ compare compounds. 
Among the compounds selected, linear alkyl hydroxamic acid series (Figure 2A) with various chain length and terminal cycles or linkers (Figure 2B) have been partially inspired by HDAC inhibitors and BoNTA inhibitors. ${ }^{4}$ Diversely $\alpha$-substituted hydroxamic acids (Figure 2C) were inspired by PfAM1 malonic inhibitors, ${ }^{8}$ LpxC inhibitors ${ }^{45}$ and $h$ IDE inhibitors ${ }^{11}$. Other compounds were selected by homology to sulfonamides or sulfone-derived inhibitors of matrix-metalloproteases (MMP). ${ }^{46}$ Hydroxamic acids inspired by inhibitors of aggrecanases $(\mathrm{AGG})^{47}$ or $\mathrm{TACE}^{48,16}$ were also designed and synthesized. Series of compounds with an unsaturation in $\alpha$-position of the hydroxamic acid function (Figure 2D) have been inspired by cinnamic HDAC inhibitors $^{49-50}$, PfAM1 inhibitors ${ }^{8}$, or BoNTA inhibitors ${ }^{4}$. Finally, a number of hydroxamic acids displaying cyclic constraints in $\alpha$-position (Figure 2E) complete the library. They were inspired by $\mathrm{MMP}^{51-52}, \mathrm{LpxC}^{53}$ and $\mathrm{TACE}^{54}$ inhibitors.

Synthesis of the library.

The studied 1-57 compounds were obtained either as previously described ${ }^{24}(\mathbf{3 7 - 3 8 , 4 0 -}$ 42, 57) or via diverse synthetic approaches $(\mathbf{1 - 3 6}, \mathbf{3 9}, \mathbf{4 3 - 5 6 )}$ summarized in schemes 1-7. Hydroxamic acids, scheme 1, were obtained either from the corresponding carboxylic acid by coupling with $O$-tritylhydroxylamine, ${ }^{55}$ or from the corresponding ester by aminolysis with either hydroxylamine hydrochloride and $\mathrm{KOH}^{56}$ or hydroxylamine and catalytic $\mathrm{KCN}^{57}(\mathbf{1 2}, \mathbf{1 5}$ 17, 19-20, 30-37, 39, 43-45, 50-51). Non-commercial precursors (22b-29b, 46b-49b, 52b, 54b56b) were synthesized as described in schemes 2-7.

Commercial 2-(adamantan-1-yl)ethan-1-ol was tosylated and the resulting sulfonate was substituted using cyanide to afford 58. Then, the nitrile was hydrolyzed under basic conditions giving the corresponding carboxylic acid, which was converted into the methyl ester 12a (Scheme 2). 
Scheme 1. From carboxylic acid or ester precursors to final hydroxamic acids. ${ }^{\mathbf{a}}$

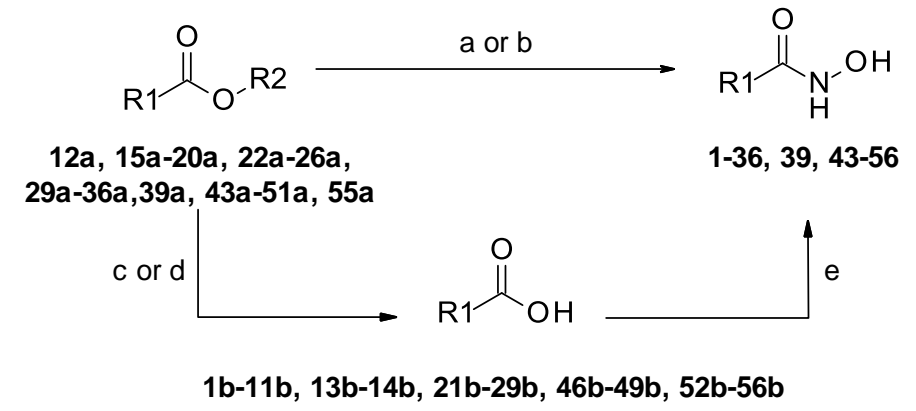

${ }^{\text {a }}$ Reagents and conditions: (a) $\mathrm{KCN}$, aq. $\mathrm{NH}_{2} \mathrm{OH} 50$ wt.\%, $\mathrm{MeOH}$, room temp., $2 \mathrm{~h}-48 \mathrm{~h}, 4 \%-88 \%$; (b) $\mathrm{NH}_{2} \mathrm{OH} . \mathrm{HCl}, \mathrm{KOH}, \mathrm{MeOH}$, room temp., $16 \mathrm{~h}, 36 \%$ yield for 18; (c) (i) $2 \mathrm{M} \mathrm{NaOH}, \mathrm{EtOH} / \mathrm{THF}$, room temp., $16 \mathrm{~h}$, (ii) $1 \mathrm{~N} \mathrm{HCl}, 52 \%-99 \%$; (d) TFA, $\mathrm{CH}_{2} \mathrm{Cl}_{2}$, room temp., $2 \mathrm{~h}$, quantitative yield; (e) (i) $O$-tritylhydroxylamine, EDCI, HOBt, N-methylmorpholine, DMF, room temp., 16 h; (ii) TFA, TIS, $\mathrm{CH}_{2} \mathrm{Cl}_{2}$, room temp., 15 min, $8 \%-99 \%$.

Scheme 2. Synthesis of adamantane derivative $12 \mathbf{a}^{\mathbf{a}}$

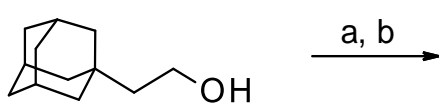

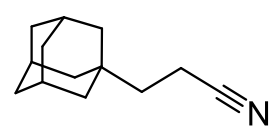

58

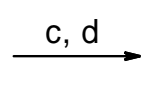<smiles>COC(=O)CCC12CC3CC(C1)C(C3)C2</smiles>

$12 a$

${ }^{a}$ Reagents and conditions: (a) 4-methylbenzenesulfonyl chloride, pyridine, room temp., $20 \mathrm{~h}, 75 \%$; (b) KCN, DMF, $80{ }^{\circ} \mathrm{C}, 15 \mathrm{~h}, 84 \%$; (c) $\mathrm{KOH}, \mathrm{EtOH}, \mathrm{H}_{2} \mathrm{O}, 90{ }^{\circ} \mathrm{C}, 20 \mathrm{~h}, 97 \%$; (d) $\mathrm{SOCl}_{2}, \mathrm{MeOH}, 0{ }^{\circ} \mathrm{C}$ to room temp., $4 \mathrm{~h}$, $21 \%$.

Scheme 3. Synthesis of the secondary amines $\mathbf{1 7 a}, \mathbf{2 7 b}-\mathbf{2 8 b}$ and cynnamyl precursors 52b, 54b, $55 \mathbf{a}$ and 56b. ${ }^{\mathbf{a}}$
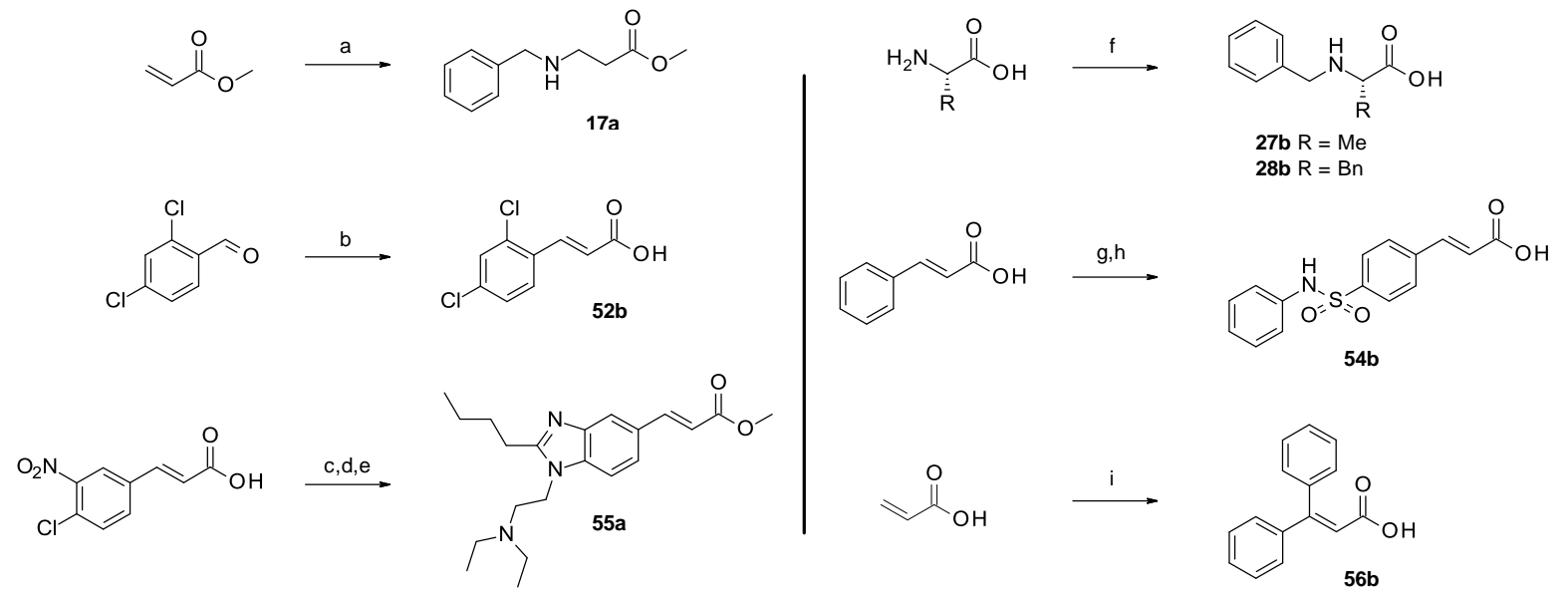

${ }^{a}$ Reagents and conditions: (a) benzylamine, EtOH, room temp., 18 h, 84\%; (b) malonic acid, pyridine, reflux, $1 \mathrm{~h}$, quantitative yield; (c) $\mathrm{MeOH}, \mathrm{H}_{2} \mathrm{SO}_{4}$, reflux, 16 h, 79\%; (d) $N, N$-diethylethylenediamine, Et $3 \mathrm{~N}$, dioxane, $90{ }^{\circ} \mathrm{C}$, 16 h, 65\%; (e) valeraldehyde, $\mathrm{SnCl}_{2} .2 \mathrm{H}_{2} \mathrm{O}, \mathrm{AcOH}, \mathrm{MeOH}, 40{ }^{\circ} \mathrm{C}, 16$ h, 48\%; (f) (i) $\mathrm{LiOH} . \mathrm{H}_{2} \mathrm{O}, \mathrm{MeOH}$, room temp., 20 min, (ii) benzaldehyde, room temp., 1 h, (iii) $\mathrm{NaBH}_{4}$, room temp., $30 \mathrm{~min}, 76 \%-100 \%$; (g) chlorosulfonic acid, 10-12 ${ }^{\circ} \mathrm{C}, 16 \mathrm{~h}, 30 \%$; (h) aniline, pyridine, $\mathrm{CH}_{2} \mathrm{Cl}_{2}$, room temp., $16 \mathrm{~h}, 66 \%$; (i) iodobenzene, silver acetate, palladium acetate, acetic acid, $110^{\circ} \mathrm{C}, 6 \mathrm{~h}, 61 \%$. 
Hydroxamic acid analogs bearing a secondary amine $(\mathbf{1 7}, \mathbf{2 7}$ and $\mathbf{2 8})$ or a cinnamyl moiety (52 and 55) were synthesized as described in Scheme 3. The linear ester precursor 17a was obtained via an aza-Michael reaction whereas a reductive amination from benzaldehyde and the corresponding amino-acid afforded acidic precursors $\mathbf{2 7 b}$ and $\mathbf{2 8 b} .{ }^{58}$ Benzenepropenoic acids 54b and 55a, analogues of HDAC inhibitors, were obtained according to the literature. ${ }^{49-}$ ${ }^{50}$ Compound $\mathbf{5 2 b}$, the acid precursor of a botulinum neurotoxin A protease inhibitor ${ }^{59}$ was synthesized by a Döbner-Knöevenagel condensation from malonic acid and 2,4dichlorobenzaldehyde. At last, disubstituted alkene 56b was synthesized by palladiumcatalyzed Heck diarylation ${ }^{60}$ (Scheme 3$)$.

Scheme 4. Synthesis of malonic precursors. ${ }^{\mathrm{a}}$<smiles>[R]C1C(=O)OC(C)(C)OC1=O</smiles><smiles>CCCCCCCCCCCCCC</smiles><smiles>[R1]NC(=O)C([R])C(=O)O</smiles>

15b $\mathrm{R}=\mathrm{H}, \mathrm{R} 1=\mathrm{Ph}$

20b $R=H, R 1=B n$ 33b R = 2-naphtyl- $-\mathrm{CH}_{2}-$, R1 = Bn<smiles>[R1]NC(=O)C([R])C(=O)OC</smiles>

15a $R=H, R 1=P h$

20a $R=H, R 1=B n$

33a $\mathrm{R}=2$-naphtyl- $\mathrm{CH}_{2}-, \mathrm{R} 1=\mathrm{Bn}$<smiles>[R]C([R])(C(=O)OCC)C(=O)OCC</smiles><smiles>[R]C([R])(C(=O)O)C(=O)OCC</smiles>

$\mathrm{R}=\mathrm{H}$

$63 \mathrm{R}^{\prime}=\mathrm{Me}$

$64 \mathrm{R}^{\prime}=\mathrm{Bn}$

$65 \mathrm{R}^{\prime}=4$-pyridinyl- $\mathrm{CH}_{2}$

$66 \mathrm{R}=\mathrm{Me}, \mathrm{R}^{\prime}=\mathrm{Bn}$

$67 \mathrm{R}=\mathrm{R}^{\prime}=\mathrm{Me}$

$68 \mathrm{R}=\mathrm{R}^{\prime}=$ cyclopropyl<smiles>[R1]NC(=O)C([R])([R])C(=O)OCC</smiles>

$\mathrm{R} 1=\mathrm{Bn}$

30a $R=H, R^{\prime}=M e$

31a $R=H, R^{\prime}=B n$

32a $\mathrm{R}=\mathrm{H}, \mathrm{R}^{\prime}=4$-pyridinyl- $\mathrm{CH}_{2}$

34a $R=M e, R^{\prime}=B n$

35a $R=M e, R^{\prime}=M e$

36a $\mathrm{R}=\mathrm{R}^{\prime}=$ cyclopropyl

$\mathrm{R}=\mathrm{H}, \mathrm{R}^{\prime}=\mathrm{Bn}$

39a $\mathrm{R} 1=p \mathrm{~F}-\mathrm{C}_{6} \mathrm{H}_{4}-\mathrm{CH}_{2}-$

43a R1 = 4-pyridinyl- $\mathrm{CH}_{2}$ -

a Reagents and conditions: (a) (i) 2-naphthaldehyde, MeCN, room temp., $1.5 \mathrm{~h}$, (ii) Hantzsch's ester, L-proline, $\mathrm{MeOH}$, room temp., $16 \mathrm{~h}, 68 \%$; (b) aniline, $\mathrm{MeCN}, 80{ }^{\circ} \mathrm{C}, 2 \mathrm{~h}, 48 \% \mathrm{15b}$, benzylamine, MeCN room temp., $3 \mathrm{~h}$, $63 \%$ 20b, benzylamine, MeCN, MW $80{ }^{\circ} \mathrm{C}, 1.75 \mathrm{~h}, 95 \%$ 33b; (c) $\mathrm{SOCl}_{2}, \mathrm{MeOH}, 0{ }^{\circ} \mathrm{C}$ to room temp., 0.5-5.25 h, 43\%-89\%; (d) (i) $\mathrm{NaH}$, THF, $0{ }^{\circ} \mathrm{C}$ to room temp., $30 \mathrm{~min}$, (ii) 4-(chloromethyl)pyridine hydrochloride, $40{ }^{\circ} \mathrm{C}, 5.5$ h, 23\%; (e) (i) Sodium, abs. EthOH, $0{ }^{\circ} \mathrm{C}$ to $50^{\circ} \mathrm{C}, 1 \mathrm{~h}$, (ii) bromomethylbenzene, $50{ }^{\circ} \mathrm{C}, 19 \mathrm{~h}, 37 \%$; (f) $\mathrm{KOH}$, EtOH, room temp., $24 \mathrm{~h}$, quantitative yield; (g) amine, HBTU, DIPEA, DMF, $0{ }^{\circ} \mathrm{C}$ to room temp., $4 \mathrm{~h}-18 \mathrm{~h}, 41 \%-$ $75 \%$. 
Malonic precursors were synthesized to explore the impact of substitution in $\alpha$-position of the hydroxamic acid function. A one-pot Knoevenagel-reduction catalyzed by L-proline gave precursor 60. ${ }^{61}$ The dissymmetric opening of the Meldrum's acids 59 and 60 with primary amines, and subsequent methyl esterification, afforded 15a, 20a, and 33a. Precursors 61 and 62 were obtained via alkylation of commercial malonic esters. Mono-saponification, followed by coupling with the corresponding amine resulted in compounds 30a-32a, 34a-36a, 39a, 43a (Scheme 4).

Scheme 5. Synthesis of phenylalkyl ester precursors 16a, 22a-26a. ${ }^{\mathbf{a}}$<smiles>COC(=O)CNCCc1ccccc1</smiles><smiles>COC(=O)CCCc1ccccc1</smiles><smiles>COC(=O)CC(=O)OC</smiles><smiles></smiles><smiles>COC(=O)C(CCc1ccccc1)Cc1ccccc1</smiles><smiles>[R]C(C(=O)OC)S([R])(=O)=O</smiles><smiles>[CH2-]C</smiles><smiles>[R]C(CCc1ccccc1)(C(=O)OC)S([R])(=O)=O</smiles>

$$
\begin{aligned}
& \text { 24a } R=P h, R^{\prime}=H \\
& \text { 25a } R=P h, R^{\prime}=M e \\
& 69 R=M e, R^{\prime}=H \\
& \text { 26a } R=M e, R^{\prime}=B n
\end{aligned}
$$

${ }^{a}$ Reagent and conditions: (a) methyl-2-bromoacetate, DIPEA, DMF, $0{ }^{\circ} \mathrm{C}$ to room temp., $4 \mathrm{~h}, 54 \%$; (b)

LDA, MeI, THF, $-78{ }^{\circ} \mathrm{C}$ to room temp., 85\%; (c) (i) (2-iodoethyl)benzene, NaH, DMF, $70{ }^{\circ} \mathrm{C}, 3.5 \mathrm{~h}, 79 \%$, (ii) benzyl bromide, NaH, DMF, toluene, room temp., 60 h, 83\%; (iii) KOH, 2-methoxyethanol/ $\mathrm{H}_{2} \mathrm{O}$ (10/1 v/v), 130 ${ }^{\circ} \mathrm{C}, 1.5 \mathrm{~h}$, then $6 \mathrm{~N} \mathrm{HCl}, 83 \%$. (d) (2-bromoethyl)benzene, $\mathrm{NaH}, \mathrm{DMF}, 0{ }^{\circ} \mathrm{C}, 1 \mathrm{~h}$ then room temp.,16 h, $90 \%$; (e) methyliodide or bromomethylbenzene, $\mathrm{NaH}, \mathrm{DMF}, 55^{\circ} \mathrm{C}$, overnight, $71 \%-78 \%$. 
Ester precursors 16a, 22a-26a were obtained as follows (Scheme 5). The 2-phenylethan1-amine was alkylated by methyl-2-bromoacetate to give ester 16a, while alkylation of methyl 4-phenylbutanoate with methyl iodide afforded compound 22a. Alkylation of dimethyl malonate with (2-iodoethyl)benzene followed by hydrolysis and decarboxylation gave methyl ester 23a. Treatment of ethyl (methylsulphonyl)acetate and ethyl (phenylsulphonyl)acetate with both sodium hydride and (2-bromoethyl)benzene afforded 69 and 24a respectively. Phenylsulfonyle 24a was alkylated with methyl iodide and sodium hydride to give 25a. In a similar manner methylsulfonyl 69 was treated with benzyl bromide, giving $26 \mathbf{a}$.

Scheme 6. Synthesis of amides $18 \mathbf{a}, 29 a, 44 a-45 a .^{a}$

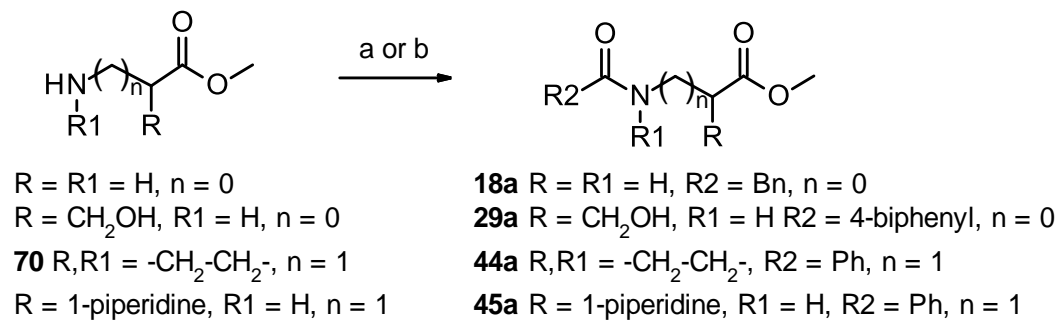

${ }^{a}$ Reagent and conditions: (a) phenyl-acetic acid, HOBt, EDCI, DIEA, DMF, room temp., 12 h-48 h, 70\%-84\%; (b) benzoyl chloride, DIPEA, $\mathrm{CH}_{2} \mathrm{Cl}_{2}, 0^{\circ} \mathrm{C}$ to room temp., $1 \mathrm{~h}-2 \mathrm{~h}, 41 \%-62 \%$.

Ester precursors 18a, 29a, 44a and 45a were synthetized via acylation reactions (Scheme 6). Sulfonamides $\mathbf{4 6 a}-\mathbf{4 7} \mathbf{a}^{46}$ and $\mathbf{5 0 a - 5 1 a ^ { 1 6 }}$ were synthesized by acylation with benzenesulfonyl chloride. At last, $\mathrm{D}^{-}$-valine and $\mathrm{D}^{-}$phenylalanine underwent $N$-sulfonylation (71, 73), followed by esterification $(\mathbf{7 2}, \mathbf{7 4})$ and $\mathrm{N}$-alkylation to afford compounds $48 \mathbf{a}$ and 49a respectively (Scheme 7). 
Scheme 7. Synthesis of sulfonylated precursors 46a-51a. ${ }^{\mathrm{a}}$

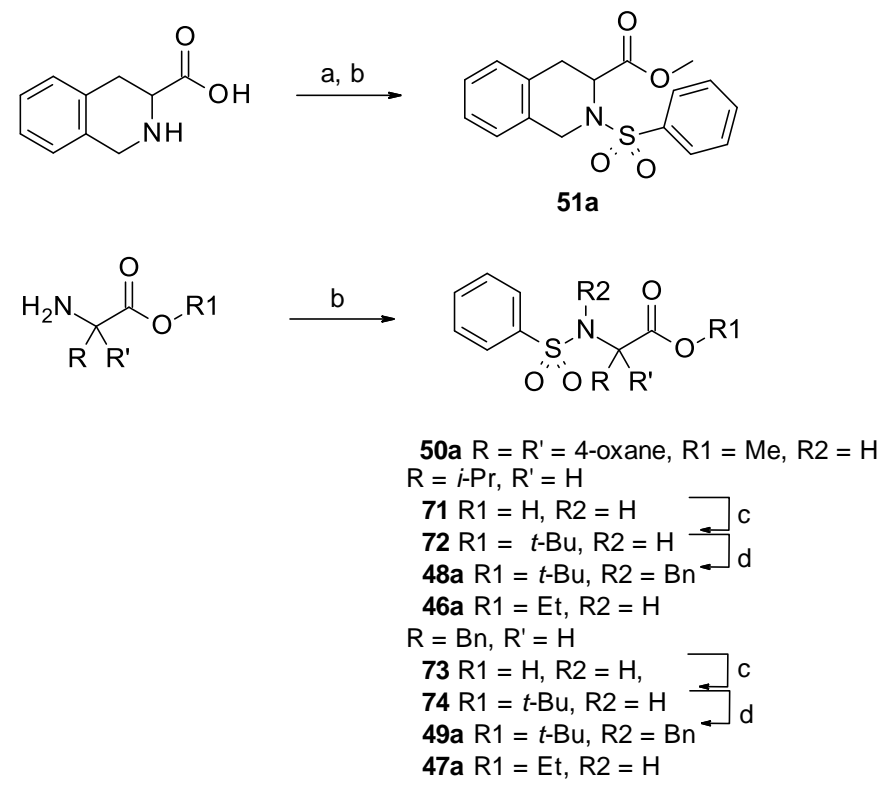

\footnotetext{
${ }^{a}$ Reagents and conditions: (a) $\mathrm{SOCl}_{2}, \mathrm{MeOH}, 0{ }^{\circ} \mathrm{C}$ to room temp., 10 days, $64 \%$; (b) benzenesulfonyl chloride, base, solvent, $0{ }^{\circ} \mathrm{C}$ to room temp., $2 \mathrm{~h}-18 \mathrm{~h}, 24 \%-66 \%$; (c) di-tert-butylacetal, toluene, DMF, $95{ }^{\circ} \mathrm{C}, 16 \mathrm{~h}, 65 \%$ $71 \%$; (d) benzyl bromide, $\mathrm{K}_{2} \mathrm{CO}_{3}$, DMF, 2 days, room temp., 87\%-96\%.
}

\section{Relations between chemical structure and plasma stability}

Compounds 1-57 were evaluated for their stability in both rat plasma and human plasma. Rat was chosen as its plasma displays high hydrolytic properties ${ }^{62}$ and it is a species often used for regulatory toxicology studies to determine therapeutic window. Half-lives in rat plasma are presented in four tables (2 to 5) highlighting the influence of chain length and composition, and nature of substituent in alpha to the hydroxamate function.

Linear compounds with saturated aliphatic linkers (1-7, Table 2): Several phenyl linear compounds were synthesized to explore the influence of the chain length on plasma stability of the hydroxamic acid function. Interestingly, when phenyl or benzyl substituents are directly linked to the hydroxamic acid function $(\mathrm{n}=0$ and 1$)$, compounds are stable while the most unstable compounds were obtained with medium chain length $(n=2,3$ and 4$)$. Then compounds with aliphatic extended linear chain $(n=5,6)$ have long half-lives (4-6 hours).

Cyclohexane $(\mathbf{8}, \mathbf{9 - 1 0})$ and adamantane derivatives $(\mathbf{1 1}, \mathbf{1 2})$ behave the same way as their phenyl analogues (2-4) (Table 2). Indeed, linker with $n=2$ or 3 are hydrolysed rapidly in 
plasma ( $\mathrm{t}_{1 / 2}<0.5$ hours), while for $\mathrm{n}=1$, compounds are stable. Interestingly both lipophilicity and size impact the rate of hydrolysis. This is exemplified by the decreasing stabilities of adamantane 12 > cyclohexane 9 displaying cLogP of 2.2 and, 2.01 and molecular volume of 161 and $120 \AA^{3}$ respectively.

Table 2: Influence of chain length, aromaticity and volume on plasma stability.

\begin{tabular}{|c|c|c|c|}
\hline & $R_{Y Y_{n}}{ }_{1-12}^{O}$ & & \\
\hline$\overline{\mathrm{Cpd}}$ & $\mathrm{R}-$ & $\overline{\mathrm{n}}$ & $\mathrm{t}_{1 / 2}(\mathrm{~h})^{\mathrm{a}}$ \\
\hline 1 & $\mathrm{Ph}-$ & 0 & $>6^{\mathrm{b}}$ \\
\hline 2 & $\mathrm{Ph}-$ & 1 & $>6^{b}$ \\
\hline 3 & $\mathrm{Ph}-$ & 2 & $0.8^{\mathrm{b}}$ \\
\hline 4 & $\mathrm{Ph}-$ & 3 & $2.0^{\mathrm{b}}$ \\
\hline 5 & $\mathrm{Ph}-$ & 4 & 0.9 \\
\hline 6 & $\mathrm{Ph}-$ & 5 & 4.5 \\
\hline 7 & Ph- & 6 & $>6$ \\
\hline 8 & $\mathrm{cHx}-$ & 1 & $>6$ \\
\hline 9 & $\mathrm{cHx}-$ & 2 & 0.06 \\
\hline 10 & cHx- & 3 & 0.05 \\
\hline 11 & Adamantyl- & 1 & $>6$ \\
\hline 12 & Adamantyl- & 2 & 0.5 \\
\hline
\end{tabular}

${ }^{\mathrm{a}}$ Half-life in rat plasma. ${ }^{\mathrm{b}}$ From reference 24.

Linear compounds with heteroatom-containing linkers(Table 3): Regardless of its size, the nature of the linear linker impacts plasmatic stabilities of hydroxamic acids Indeed, halflives vary from 0.6 to more than 6 hours for a 3 -atom linker and from 0.3 to more than 6 hours for a 4-atom linker respectively. Interestingly, linear alkyl compounds $\mathbf{4}$ and $\mathbf{5}$ are not the most stable hydroxamic acids in the series. Introduction of a secondary amine is either beneficial for stability (13 vs $\mathbf{4}$ or $\mathbf{1 7}$ vs $\mathbf{5}$ ) or deleterious (16 vs $\mathbf{5}$ ). The presence of an amide function in $\beta$ or $\gamma$ - position of the hydroxamic acid is critical for stability (20 vs 21 and 18 vs 19). Also, hydroxamic acids $\mathbf{1 4}$ and $\mathbf{1 8}$ derived of glycine are far less stable than their retro-amide analogs 15 and 20 respectively, which are the most stable compounds in the series (Table 3). 
Table 3: Influence of the nature of the linear linker.

\begin{tabular}{|c|c|c|c|}
\hline Cpd & Linker & "n" & $\mathrm{t}_{1 / 2}(\mathrm{~h})^{\mathrm{a}}$ \\
\hline 4 & $-\mathrm{CH}_{2}-\mathrm{CH}_{2}-\mathrm{CH}_{2}-$ & 3 & $2.0^{\mathrm{b}}$ \\
\hline 13 & $-\mathrm{CH}_{2}-\mathrm{NH}-\mathrm{CH}_{2}-$ & 3 & 3.6 \\
\hline 14 & $-\mathrm{CO}-\mathrm{NH}-\mathrm{CH}_{2}-$ & 3 & 0.58 \\
\hline 15 & $-\mathrm{NH}-\mathrm{CO}-\mathrm{CH}_{2-}$ & 3 & $>6$ \\
\hline 5 & $-\mathrm{CH}_{2}-\mathrm{CH}_{2}-\mathrm{CH}_{2}-\mathrm{CH}_{2}-$ & 4 & 0.93 \\
\hline 16 & $-\mathrm{CH}_{2}-\mathrm{CH}_{2}-\mathrm{NH}-\mathrm{CH}_{2}-$ & 4 & 0.5 \\
\hline 17 & $-\mathrm{CH}_{2}-\mathrm{NH}-\mathrm{CH}_{2}-\mathrm{CH}_{2}-$ & 4 & 2.1 \\
\hline 18 & $-\mathrm{CH}_{2}-\mathrm{CO}-\mathrm{NH}-\mathrm{CH}_{2}-$ & 4 & 0.29 \\
\hline 19 & $-\mathrm{CO}-\mathrm{NH}-\mathrm{CH}_{2}-\mathrm{CH}_{2}-$ & 4 & 2.5 \\
\hline 20 & $-\mathrm{CH}_{2}-\mathrm{NH}-\mathrm{CO}-\mathrm{CH}_{2}-$ & 4 & $>6$ \\
\hline 21 & -NH-CO-CH$-\mathrm{CH}_{2}-\mathrm{CH}_{2}$ & 4 & 0.43 \\
\hline
\end{tabular}

${ }^{\mathrm{a}}$ Half-life in rat plasma. ${ }^{\mathrm{b}}$ From reference 24.

Impact of the substituent in $\alpha$-position to the hydroxamate (Table 4): In the series of 4phenylbutanehydroxamic acid $\mathbf{4}$, introduction of a substituent in $\alpha$-position results in a higher plasma stability (22-26). On the contrary, in 2-(benzylamino)ethanehydroxamic acid series (13, 27-29) and malono-hydroxamic series (20, 30-43), introduction of benzyl substituent or arylmethyl groups is deleterious for stability $(\mathbf{2 8}, \mathbf{3 1 - 3 4}, \mathbf{3 9 - 4 0}, \mathbf{4 3})$, in comparison with smaller substituents like methyl $(\mathbf{2 7}, \mathbf{3 0}, \mathbf{3 8})$. Interestingly, the size and nature of the aryl-methyl group in alpha positions impacts stability: pyridine > phenyl > naphthyl (31-33).

Surprisingly, groups at long distance from the hydroxamic acid can also impact stability. Indeed, pyridinyl compound 43 is much more stable $\left(\mathrm{t}_{1 / 2}=3.3 \mathrm{~h}\right)$ than benzyl and $p$ fluorobenzyl analogues $(31,39)\left(t_{1 / 2}=0.8 \mathrm{~h}\right)$, although 43 contains a benzyl group in $\alpha$-position, a substructure shown above to accelerate hydrolysis by plasma. Gem-dimethyl substitution or introduction of a cyclopropyl group allow obtention of stable compounds (35-36; 41-42). Introduction of a methyl group in $\alpha$-position moderately restores stability for benzyl-substituted

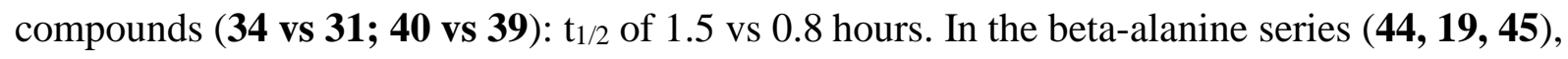
introduction of a cyclic constraints protects from hydrolysis $\left(44, \mathrm{t}_{1 / 2}>6 \mathrm{~h}\right)$ while introduction of a positive charge results in poorly stable compound $\left(45 t_{1 / 2}=0.4 h\right)$. In comparison with 
these beta-alanine derivatives, serine-base compound 29 is stable. Finally, in the sulfonamide series the presence of an isopropyl group prevents hydrolysis $(\mathbf{4 6}, \mathbf{4 8})$ while a benzyl group promotes it (47). Interestingly, substitution of the nitrogen of the adjacent amide function by a benzyl group restores plasmatic stability (49 vs $\mathbf{4 7}$ ) but freezing $\alpha$-position substituent with the amide substituent into a tetrahydroquinoline is deleterious for stability (51). As gemsubstitution was tolerated in other series, it is also protective in sulfonamide series (50).

Table 4: Impact of substitution in $\alpha$-position of the hydroxamic acid function.<smiles>[R]C([R])([Y])C(=O)NO</smiles>

$4,13,19,22-51$

\begin{tabular}{|c|c|c|c|c|c|c|}
\hline $\mathrm{Ar}-$ & $n$ & $\mathrm{X}$ & $-\mathrm{R}^{\prime}$ & $-\mathrm{R}$ & $-\mathrm{R}_{1}$ & \\
\hline $4 \mathrm{Ph}-$ & 1 & $\mathrm{CH}_{2}$ & $-\mathrm{H}$ & $-\mathrm{H}$ & & $2.0^{\mathrm{b}}$ \\
\hline $22 \mathrm{Ph}-$ & 1 & $\mathrm{CH}_{2}$ & $-\mathrm{H}$ & $-\mathrm{CH}_{3}$ & & $>6$ \\
\hline $23 \mathrm{Ph}-$ & 1 & $\mathrm{CH}_{2}$ & $-\mathrm{H}$ & $-\mathrm{CH}_{2}-\mathrm{Ph}$ & & $>6$ \\
\hline $24 \mathrm{Ph}-$ & 1 & $\mathrm{CH}_{2}$ & $-\mathrm{H}$ & $-\mathrm{SO}_{2}-\mathrm{Ph}$ & & $>6$ \\
\hline $25 \mathrm{Ph}-$ & 1 & $\mathrm{CH}_{2}$ & $-\mathrm{SO}_{2}-\mathrm{Ph}$ & $-\mathrm{CH}_{3}$ & & $>6$ \\
\hline $26 \mathrm{Ph}-$ & 1 & $\mathrm{CH}_{2}$ & $-\mathrm{SO}_{2}-\mathrm{CH}_{3}$ & $-\mathrm{CH}_{2}-\mathrm{Ph}$ & & $>6$ \\
\hline $13 \mathrm{Ph}-$ & 1 & $\mathrm{NH}$ & $-\mathrm{H}$ & $-\mathrm{H}$ & & 3.6 \\
\hline $27 \mathrm{Ph}-$ & 1 & $\mathrm{NH}$ & $-\mathrm{H}$ & $-\mathrm{CH}_{3}$ & & $>6$ \\
\hline $28 \mathrm{Ph}-$ & 1 & $\mathrm{NH}$ & $-\mathrm{H}$ & $-\mathrm{CH}_{2}-\mathrm{Ph}$ & & 1.8 \\
\hline $20 \mathrm{Ph}-$ & 1 & $\mathrm{NHCO}$ & $-\mathrm{H}$ & $-\mathrm{H}$ & & $>6$ \\
\hline $30 \mathrm{Ph}-$ & 1 & NHCO & $-\mathrm{H}$ & $-\mathrm{CH}_{3}$ & & $>6$ \\
\hline $31 \mathrm{Ph}-$ & 1 & $\mathrm{NHCO}$ & $-\mathrm{H}$ & $-\mathrm{CH}_{2}-\mathrm{Ph}$ & & 0.8 \\
\hline $32 \mathrm{Ph}-$ & 1 & $\mathrm{NHCO}$ & $-\mathrm{H}$ & $-\mathrm{CH}_{2}-4$-pyridinyl & & 4.5 \\
\hline $33 \mathrm{Ph}-$ & 1 & NHCO & $-\mathrm{H}$ & $-\mathrm{CH}_{2}-2$-naphthyl & & 0.1 \\
\hline $34 \mathrm{Ph}-$ & 1 & $\mathrm{NHCO}$ & $-\mathrm{CH}_{3}$ & $-\mathrm{CH}_{2}-\mathrm{Ph}$ & & 1.5 \\
\hline $35 \mathrm{Ph}-$ & 1 & $\mathrm{NHCO}$ & $-\mathrm{CH}_{3}$ & $-\mathrm{CH}_{3}$ & & $>6$ \\
\hline $36 \mathrm{Ph}-$ & 1 & $\mathrm{NHCO}$ & -сус & lopropyl- & & $>6$ \\
\hline $37 p \mathrm{~F}-\mathrm{C}_{6} \mathrm{H}_{4-}$ & 1 & $\mathrm{NHCO}$ & $-\mathrm{H}$ & $-\mathrm{H}$ & & $>6$ \\
\hline $38 p \mathrm{~F}-\mathrm{C}_{6} \mathrm{H}_{4-}$ & 1 & NHCO & $-\mathrm{H}$ & $-\mathrm{CH}_{3}$ & & $>6$ \\
\hline $39 \mathrm{pF}-\mathrm{C}_{6} \mathrm{H}_{4-}$ & 1 & NHCO & $-\mathrm{H}$ & $-\mathrm{CH}_{2}-\mathrm{Ph}$ & & $0.8^{\mathrm{b}}$ \\
\hline $40 p \mathrm{~F}-\mathrm{C}_{6} \mathrm{H}_{4-}$ & 1 & $\mathrm{NHCO}$ & $-\mathrm{CH}_{3}$ & $-\mathrm{CH}_{2}-\mathrm{Ph}$ & & $1.5^{b}$ \\
\hline $41 p \mathrm{~F}-\mathrm{C}_{6} \mathrm{H}_{4}-$ & 1 & $\mathrm{NHCO}$ & $-\mathrm{CH}_{3}$ & $-\mathrm{CH}_{3}$ & & $>6^{\mathrm{b}}$ \\
\hline $42 p \mathrm{~F}-\mathrm{C}_{6} \mathrm{H}_{4}-$ & 1 & $\mathrm{NHCO}$ & - сус & lopropyl- & & $>6^{\mathrm{b}}$ \\
\hline 43 4-pyridinyl- $\mathrm{CH}_{2}-$ & 1 & $\mathrm{NHCO}$ & $-\mathrm{H}$ & $-\mathrm{CH}_{2}-\mathrm{Ph}$ & & 3.3 \\
\hline $19 \mathrm{Ph}-$ & 0 & $\mathrm{CONHCH}_{2}$ & $-\mathrm{H}$ & & $-\mathrm{H}$ & 2.5 \\
\hline $44 \mathrm{Ph}-$ & 0 & $\mathrm{CONR}_{1} \mathrm{CH}_{2}$ & $-\mathrm{H}$ & $-\mathrm{CH}_{2-}$ & $\mathrm{CH}_{2-}$ & $>6$ \\
\hline $45 \mathrm{Ph}-$ & 0 & $\mathrm{CONHCH}_{2}$ & $-\mathrm{H}$ & -piperidinyl & $-\mathrm{H}$ & 0.4 \\
\hline 29 4-biphenyl- & 0 & $\mathrm{CONH}$ & $-\mathrm{H}$ & $-\mathrm{CH}_{2} \mathrm{OH}$ & $-\mathrm{H}$ & $>6$ \\
\hline $46 \mathrm{Ph}-$ & 0 & $\mathrm{SO}_{2} \mathrm{NR}_{1}$ & $-\mathrm{H}$ & $-\mathrm{iPr}$ & $-\mathrm{H}$ & $>6^{\mathrm{b}}$ \\
\hline $47 \mathrm{Ph}-$ & 0 & $\mathrm{SO}_{2} \mathrm{NR}_{1}$ & $-\mathrm{H}$ & $-\mathrm{CH}_{2}-\mathrm{Ph}$ & $-\mathrm{H}$ & 0.1 \\
\hline $48 \mathrm{Ph}-$ & 0 & $\mathrm{SO}_{2} \mathrm{NR}_{1}$ & $-\mathrm{H}$ & $-\mathrm{iPr}$ & $-\mathrm{CH}_{2}-\mathrm{Ph}$ & $>6$ \\
\hline $49 \mathrm{Ph}-$ & 0 & $\mathrm{SO}_{2} \mathrm{NR}_{1}$ & $-\mathrm{H}$ & $-\mathrm{CH}_{2}-\mathrm{Ph}$ & $-\mathrm{CH}_{2}-\mathrm{Ph}$ & $>6$ \\
\hline 50 Ph- & 0 & $\mathrm{SO}_{2} \mathrm{NR}_{1}$ & $-\mathrm{CH}_{2}-\mathrm{CH}$ & $\mathrm{H}_{2}-\mathrm{O}-\mathrm{CH}_{2}-\mathrm{CH}_{2}-$ & $-\mathrm{H}$ & $>6$ \\
\hline $51 \mathrm{Ph}-$ & 0 & $\mathrm{SO}_{2} \mathrm{NR}_{1}$ & $-\mathrm{H}$ & & & 0.7 \\
\hline
\end{tabular}

${ }^{\mathrm{a}}$ Half-life in rat plasma. ${ }^{\mathrm{b}}$ From reference 24. 
Introduction of a double bond in $\alpha$-position of the hydroxamic acid impacts stability. For example, compound $\mathbf{5 7}$ is stable while its saturated analogue $\mathbf{3}$ is rapidly hydrolyzed $\left(\mathrm{t}_{1 / 2}=\right.$ $0.8 \mathrm{~h}$ ) (Table 5). Other unsaturated compounds inspired by bioactive structures are stable in rat plasma (Table 5).

Table 5: Influence of unsaturation.

\begin{tabular}{|c|c|c|c|}
\hline & ${ }_{3}^{\mathrm{R}^{\prime}} \mathrm{N}_{\mathrm{H}^{-}}^{\mathrm{O}}$ & R' & \\
\hline$\overline{\mathrm{Cpd}}$ & $\overline{\mathrm{R}}$ & $\mathrm{R}^{\prime}$ & $\overline{\mathrm{t}_{1 / 2}(\mathrm{~h})^{\mathrm{a}}}$ \\
\hline 3 & $\mathrm{Ph}-$ & $\mathrm{H}-$ & 0.8 \\
\hline 52 & 1,3-dichlorophenyl- & $\mathrm{H}-$ & $>6$ \\
\hline 53 & 4-biphenyl- & $\mathrm{H}-$ & $>6$ \\
\hline 54 & $\mathrm{p}-\left(\mathrm{Ph}-\mathrm{NHSO}_{2}\right)-\mathrm{C}_{6} \mathrm{H}_{4}-$ & $\mathrm{H}-$ & $>6$ \\
\hline 55 & & $\mathrm{H}-$ & $>6$ \\
\hline 56 & $\mathrm{Ph}-$ & $\mathrm{Ph}$ & $>6$ \\
\hline $\mathbf{5 7}$ & $\mathrm{Ph}-$ & $\mathrm{H}-$ & $>6^{b}$ \\
\hline
\end{tabular}

${ }^{\mathrm{a}}$ Half-life in rat plasma. ${ }^{\mathrm{b}}$ From reference 24.

\section{Impact of physical-chemical properties on stability.}

Table 6 presents the measured stability and physical chemical properties of the 57 hydroxamic acids. In an attempt to correlate these properties of compounds with plasma stability, we looked at the distribution of 6 continuous parameters for stable $\left(\mathrm{t}_{1 / 2}>6 \mathrm{~h}\right)$ and unstable $\left(\mathrm{t}_{1 / 2}<6 \mathrm{~h}\right)$ compounds: $\operatorname{cLog} \mathrm{P}, \mathrm{cLogD} \mathrm{D}_{7.4}$, Polar Surface Area (PSA), aqueous solubility (cLogS), Molecular Weight and Volume. No difference of distribution between unstable and stable compounds were observed for cLogS, Volume or PSA. However, unstable hydroxamic acids tend to have a higher cLogP $(36 \%$ of compounds with cLogP in $[0 ; 1.5[$ range and $52 \%$ with cLogP in $[1.5 ; 3[$ ) than stable compounds $(50 \%$ of compounds with cLogP in $[0 ; 1.5[$ range and $28 \%$ with cLogP in [1.5;3[) (Supplementary Figure S8). The same difference in distribution is observed for cLogD (Supplementary Figure S8). This is well illustrated in the malonic- 
derived hydroxamic acids $\mathbf{2 0 - 4 3}$ (Table 4) where compounds displaying short half-lives have a higher cLogP than those displaying a higher half-life. For example pyridine lowers cLogP in comparison with benzene, and also impacts positively stability (32 and $\mathbf{4 3})$.

We then performed an analysis including the (categorical) HBD and HBA parameters. Indeed, a Chi-square test showed a link between stability and HBD $<3(p=0.068)$. This led us to perform a multivariate analysis using HBD along with the 6 other continuous variables. A stepwise logistic regression yielded a model with HBD, MW and Volume. It shows that HBD $<3$ favors stability $(O R=4.80)$, along with a higher molecular weight $(O R=1.06)$ and lower volume $(O R=0.91)$.

Table 6: Physical-chemical properties of compounds.

\begin{tabular}{|c|c|c|c|c|c|c|c|c|c|}
\hline Cpd & $\mathbf{t}_{1 / 2}(\mathbf{h})^{\mathbf{a}}$ & $c \log P^{b}$ & cLogD & $\mathbf{P S A}^{\mathbf{b}}$ & $\mathrm{cLogS}^{\mathrm{b}}$ & MW & Volume $^{\text {b }}$ & HBD $^{c}$ & HBA $^{c}$ \\
\hline 1 & $>6$ & 0.84 & 0.83 & 49.3 & -1.41 & 137.1 & 80.9 & 2 & 2 \\
\hline 2 & $>6$ & 0.88 & 0.87 & 49.3 & -1.72 & 151.2 & 99.1 & 2 & 2 \\
\hline 3 & 0.8 & 1.34 & 1.33 & 49.3 & -2.13 & 165.2 & 108.7 & 2 & 2 \\
\hline 4 & 2.0 & 1.79 & 1.79 & 49.3 & -2.58 & 179.2 & 122.8 & 2 & 2 \\
\hline 5 & 0.9 & 2.25 & 2.25 & 49.3 & -3.07 & 193.2 & 131.7 & 2 & 2 \\
\hline 6 & 4.5 & 2.70 & 2.70 & 49.3 & -3.57 & 207.3 & 143.7 & 2 & 2 \\
\hline 7 & $>6$ & 3.16 & 3.16 & 49.3 & -4.09 & 221.3 & 158.1 & 2 & 2 \\
\hline 8 & $>6$ & 1.55 & 1.55 & 49.3 & -1.90 & 157.2 & 110.8 & 2 & 2 \\
\hline 9 & 0.06 & 2.01 & 2.01 & 49.3 & -2.41 & 171.2 & 121.4 & 2 & 2 \\
\hline 10 & 0.05 & 2.46 & 2.46 & 49.3 & -2.94 & 185.3 & 135.5 & 2 & 2 \\
\hline 11 & $>6$ & 1.77 & 1.77 & 49.3 & -2.69 & 209.3 & 145.8 & 2 & 2 \\
\hline 12 & 0.5 & 2.23 & 2.22 & 49.3 & -3.27 & 223.3 & 159.5 & 2 & 2 \\
\hline 13 & 3.6 & 0.23 & -0.34 & 61.4 & -1.89 & 180.2 & 119.7 & 3 & 3 \\
\hline 14 & 0.58 & -0.10 & -0.24 & 78.4 & -1.81 & 194.2 & 119.7 & 3 & 3 \\
\hline 15 & $>6$ & 0.15 & 0.15 & 78.4 & -1.83 & 194.2 & 121.8 & 3 & 3 \\
\hline 16 & 0.5 & 0.56 & -0.01 & 61.4 & -2.34 & 194.2 & 129.7 & 3 & 3 \\
\hline 17 & 2.1 & 0.48 & -1.41 & 61.4 & -2.23 & 194.2 & 129.3 & 3 & 3 \\
\hline 18 & 0.29 & -0.06 & -0.20 & 78.4 & -2.10 & 208.2 & 131.7 & 3 & 3 \\
\hline 19 & 2.5 & 0.15 & 0.15 & 78.4 & -2.00 & 208.2 & 132.1 & 3 & 3 \\
\hline 20 & $>6$ & 0.15 & 0.15 & 78.4 & -2.15 & 208.2 & 131.0 & 3 & 3 \\
\hline 21 & 0.43 & 0.18 & 0.18 & 78.4 & -1.99 & 208.2 & 132.1 & 3 & 3 \\
\hline 22 & $>6$ & 2.25 & 2.25 & 49.3 & -2.95 & 193.2 & 133.8 & 2 & 2 \\
\hline 23 & $>6$ & 3.74 & 3.74 & 49.3 & -5.00 & 269.3 & 181.4 & 2 & 2 \\
\hline 24 & $>6$ & 2.72 & 2.87 & 91.9 & -4.44 & 319.4 & 199.6 & 2 & 4 \\
\hline 25 & $>6$ & 3.03 & 3.02 & 91.9 & -4.61 & 333.4 & 212.3 & 2 & 4 \\
\hline 26 & $>6$ & 3.01 & 3.00 & 91.9 & -4.91 & 347.4 & 225.4 & 2 & 4 \\
\hline 27 & $>6$ & 0.72 & 0.12 & 61.4 & -2.31 & 194.2 & 130.0 & 3 & 3 \\
\hline 28 & 1.8 & 2.27 & 2.26 & 61.4 & -4.30 & 270.3 & 180.4 & 3 & 3 \\
\hline 29 & $>6$ & 1.02 & 0.99 & 98.7 & -4.05 & 300.3 & 180.4 & 4 & 4 \\
\hline 30 & $>6$ & 0.62 & 0.63 & 78.4 & -2.67 & 222.2 & 143.4 & 3 & 3 \\
\hline 31 & 0.8 & 2.10 & 2.12 & 78.4 & -4.50 & 298.3 & 192.8 & 3 & 3 \\
\hline 32 & 4.5 & 0.95 & 0.95 & 91.3 & -4.04 & 299.3 & 190.4 & 3 & 4 \\
\hline 33 & 0.1 & 3.01 & 3.03 & 78.4 & -6.20 & 348.4 & 226.0 & 3 & 3 \\
\hline 34 & 1.5 & 2.52 & 2.52 & 78.4 & -4.76 & 312.4 & 204.8 & 3 & 3 \\
\hline 35 & $>6$ & 1.03 & 1.03 & 78.4 & -2.95 & 236.3 & 155.0 & 3 & 3 \\
\hline
\end{tabular}




\begin{tabular}{cccccccccc}
\hline $\mathbf{3 6}$ & $>6$ & 0.66 & 0.66 & 78.4 & -2.49 & 234.3 & 148.2 & 3 & 3 \\
$\mathbf{3 7}$ & $>6$ & 0.36 & 0.35 & 78.4 & -2.45 & 226.2 & 137.9 & 3 & 3 \\
$\mathbf{3 8}$ & $>6$ & 0.82 & 0.83 & 78.4 & -2.98 & 240.2 & 152.6 & 3 & 3 \\
$\mathbf{3 9}$ & $0.8^{\mathrm{b}}$ & 2.31 & 2.32 & 78.4 & -4.77 & 316.3 & 198.9 & 3 & 3 \\
$\mathbf{4 0}$ & $1.5^{\mathrm{b}}$ & 2.73 & 2.73 & 78.4 & -5.01 & 330.4 & 212.7 & 3 & 3 \\
$\mathbf{4 1}$ & $>6^{\mathrm{b}}$ & 1.24 & 1.24 & 78.4 & -3.24 & 254.3 & 165.7 & 3 & 3 \\
$\mathbf{4 2}$ & $>6$ & 0.87 & 0.87 & 78.4 & -2.77 & 252.2 & 154.0 & 3 & 3 \\
$\mathbf{4 3}$ & 3.3 & 0.95 & 0.95 & 91.3 & -4.03 & 299.3 & 190.7 & 3 & 4 \\
$\mathbf{4 4}$ & $>6$ & 0.41 & 0.41 & 69.6 & -1.75 & 234.3 & 149.2 & 2 & 3 \\
$\mathbf{4 5}$ & 0.4 & 1.10 & 0.64 & 81.7 & -2.67 & 291.4 & 193.5 & 3 & 4 \\
$\mathbf{4 6}$ & $>6$ & 0.93 & 0.93 & 103.9 & -2.87 & 272.3 & 167.7 & 3 & 4 \\
$\mathbf{4 7}$ & 0.1 & 1.65 & 1.64 & 103.9 & -4.06 & 320.4 & 193.8 & 3 & 4 \\
$\mathbf{4 8}$ & $>6$ & 2.72 & 2.71 & 95.1 & -4.61 & 362.4 & 236.0 & 2 & 4 \\
$\mathbf{4 9}$ & $>6$ & 3.44 & 3.43 & 95.1 & -5.77 & 410.5 & 257.6 & 2 & 4 \\
$\mathbf{5 0}$ & $>6$ & -0.48 & -0.48 & 113.1 & -2.00 & 300.3 & 182.8 & 3 & 5 \\
$\mathbf{5 1}$ & 0.7 & 1.61 & 1.61 & 95.1 & -3.60 & 332.4 & 200.7 & 2 & 4 \\
$\mathbf{5 2}$ & $>6$ & 2.64 & 2.64 & 49.3 & -3.96 & 232.1 & 136.5 & 2 & 2 \\
$\mathbf{5 3}$ & $>6$ & 2.83 & 2.83 & 49.3 & -4.75 & 239.3 & 150.9 & 2 & 2 \\
$\mathbf{5 4}$ & $>6$ & 1.80 & 1.80 & 103.9 & -4.36 & 318.4 & 192.1 & 3 & 4 \\
$\mathbf{5 5}$ & $>6$ & 3.71 & 2.28 & 70.4 & -5.80 & 358.5 & 256.6 & 2 & 4 \\
$\mathbf{5 6}$ & $>6$ & 2.79 & 2.79 & 49.3 & -4.30 & 239.3 & 148.9 & 2 & 2 \\
$\mathbf{5 7}$ & $>6$ & 1.31 & 1.31 & 49.3 & -2.41 & 163.2 & 99.1 & 2 & 2 \\
\hline
\end{tabular}

${ }^{a}$ Half-life in rat plasma. ${ }^{b} \operatorname{cLogP}, \operatorname{cLogD}$, PSA in $\AA^{2}, S$ in mol/L, Volume in $\AA^{3}$ calculated by PipelinePilot. ${ }^{c}$ Hydrogen-bond donors; Hydrogen-bond acceptors.

\section{Implication of esterases}

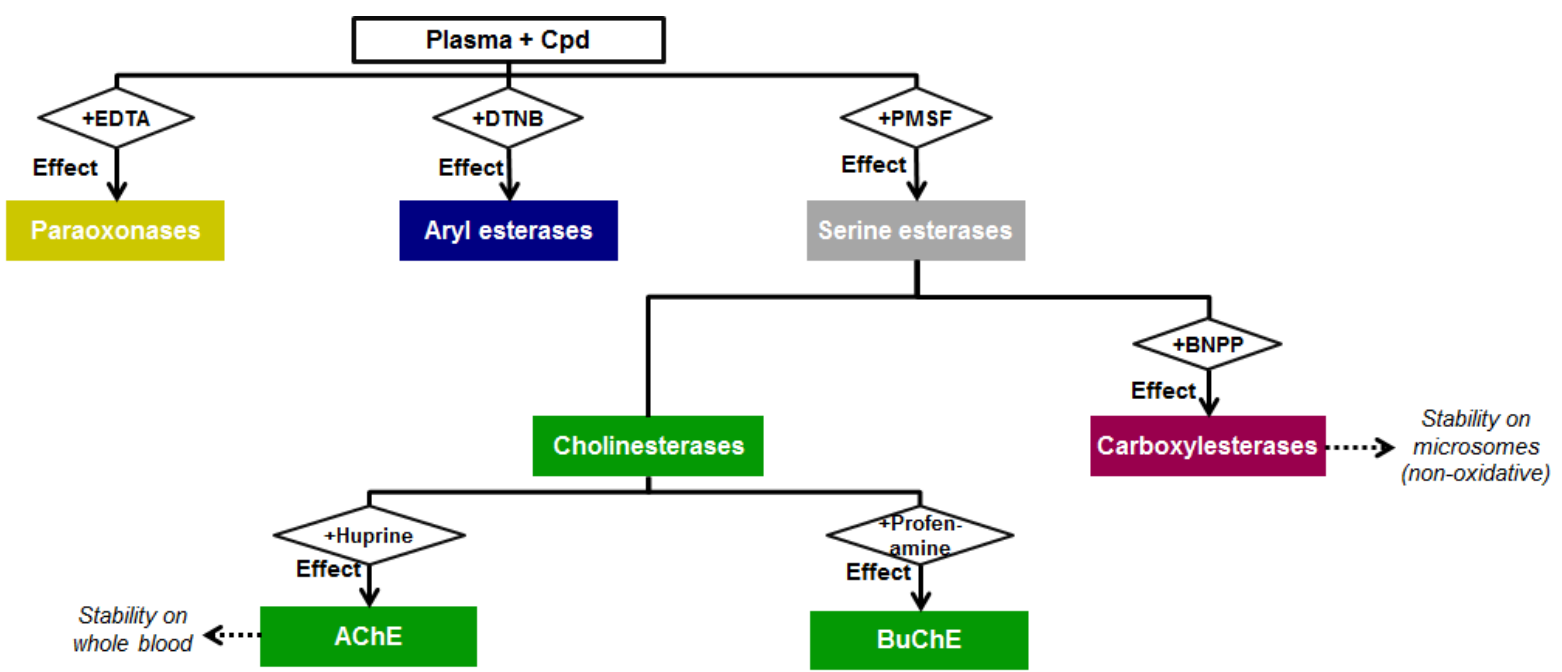

Figure 3: Inhibitor-based esterase profiling scheme.

To find which esterase(s) was (were) responsible for the hydrolysis of the unstable compounds, and attempt to rationalize SPSR with the structure of their catalytic sites, we measured and compared half-lives of unstable hydroxamic acids in the presence and absence of non-selective and selective esterase inhibitors (Figure 3 and Figures S1). We then calculated a score $\mathrm{S}$ for each esterase activity for a given hydroxamic acid and displayed results as 
dashboards (Figure 4 and Supplementary methods) to provide a visual tool to compare the behavior of compounds in the light of the structure.

First, none of the hydroxamic acids is stabilized by the addition of EDTA to plasma, excluding paraoxonase from the set of hydroxamates hydrolyzing enzymes. Most linear analogues (A, B, Figure 4) that are unstable in plasma are usually stabilized by both DTNB (arylesterase inhibitor) and PMSF (serine esterase inhibitor), while branched hydroxamic acids (C, Figure 4) are not stabilized by DTNB.

In linear series, where the linker bears either methylene groups, amide groups or secondary amines, our study reveals implication of various esterases activities. In the first series (A), shorter chain lengths $(\leq 3)$ are highly hydrolyzed by arylesterases and carboxylesterases $(\mathbf{3}, \mathbf{4})$ (Figure 4). Longer chains $(\mathrm{n}=4$ or 5$)$ are moderately hydrolyzed by these enzymes $(\mathbf{5}, \mathbf{6})$ (Figure 4). Compound 12 is not stabilized by DTNB addition to plasma, in strong contrast with other linear hydroxamic acids, probably due to both bulkiness and lipophilicity of adamantyl group in comparison to phenyl (12 vs $\mathbf{3}$ ). Also, cholinesterases are only moderately implicated in the instability of these series. Interestingly, while BuChE is not involved in the hydrolysis of $5(n=4)$, it does participate in the instability of shorter compound $4(n=3)$ (Figure 4). Noteworthy, we were unable to stabilize hydroxamic acids 9 and 10, both bearing a cyclohexyle side chain.

Introduction of a positive charge in $\beta$-position of the hydroxamic acid protects from hydrolysis by BuChE (13 vs $\mathbf{3}$ ) when chain length is 3 while, it protects from hydrolysis by arylesterases (16 vs $\mathbf{5}$ ) when chain length is 4. Conversely, introduction of a positive charge in $\gamma$-position of the hydroxamic acid, though improving stability, does not change the esterase activities implicated (17 vs $\mathbf{5})$. 
Figure 4 : Involvement of esterase activities in the hydrolysis of a given hydroxamic acid. ${ }^{\mathrm{a}}$

$n=2 \quad n=3 \quad n=4 \quad n=5$
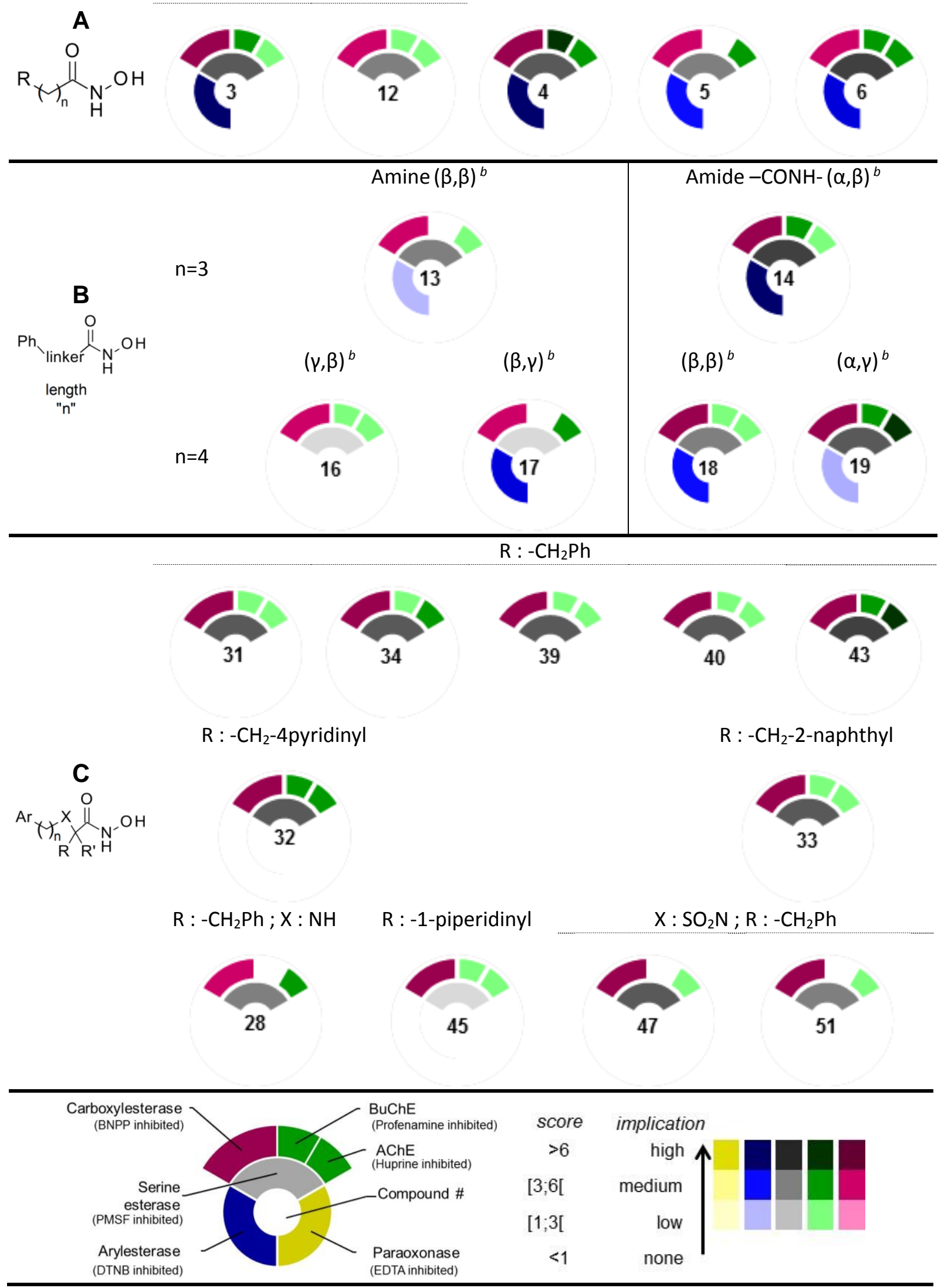

$\overline{{ }^{a} \text { Using score S calculated as given in Supplementary Methods. }{ }^{\mathrm{b}} \text { Positions of the amine or the amide (from } \mathrm{Ph}-\text {; }}$ from - $\mathrm{CONHOH})$. 
In the linear series, carboxylesterases seem more implicated in the hydrolysis of amidecontaining compounds. Though no clear differences could be seen between 14, 18 and 19, no esterase inhibitor was able to stabilize related amide 21, the reverse amide of $\mathbf{1 9 .}$

Substitution in $\alpha$-position (C, Figure 4) prevents hydrolysis by arylesterases while reinforcing hydrolysis by carboxylesterases. In malonic series $(\mathbf{3 1 - 3 4}, \mathbf{3 9 - 4 0}, \mathbf{4 3})$, presence of a benzyl group, or 2-naphthyl-methyl or 4-pyridinyl-methyl analogues, results in similar susceptibility profiles. Interestingly, introduction of a positive charge (secondary amine) in $\beta$ position of the hydroxamic function reduces the involvement of BuChE as previously described in linear series ( 28 vs $\mathbf{1 3}$ or $\mathbf{1 7}$ ), while introduction of a positive charge (tertiary amine) in $\beta$ position (45) has no effect. This can be attributed to both steric constraints in $\mathbf{4 5}$ and to the absence of a benzyl substituent. At last, in sulfonamide series, generally quite stable, introduction of the benzyl group in $\alpha$-position of the hydroxamic acid increased sensitivity to carboxylesterases, and AChE to a lesser extent.

Our study has also identified highly unstable hydroxamates 9, 10, 21 (Tables 2,3) for which no esterase inhibitor could restore stability in plasma. Co-incubation with a mixture of highly concentrated esterase inhibitors only slightly improves their half-lives by two-fold. We hypothesized that these hydroxamic acids were extremely affine substrates for esterases. To check this, we used them as competitors for other hydroxamic acids. For example, compound 4, which displays an average half-life of 2 hours, is highly stabilized in the presence of either competitor 9, 10 and 21 and its half-life is increased by 10-fold at least (Table 7 and Figure 5).

\section{Table 7: Stabilization of 4.}

\begin{tabular}{cc} 
competitor & $\mathrm{t}_{1 / 2}(\mathrm{~h})^{\mathrm{a}}$ \\
\hline none & 2.0 \\
$\mathbf{2 1}$ & 20.0 \\
$\mathbf{1 0}$ & 30.9 \\
$\mathbf{9}$ & 22.6 \\
${ }^{\mathrm{a}}$ Half-life in rat plasma of $\mathbf{4}(10 \mu \mathrm{M})$ in the absence or presence of competitor at $80 \mu \mathrm{M}$.
\end{tabular}




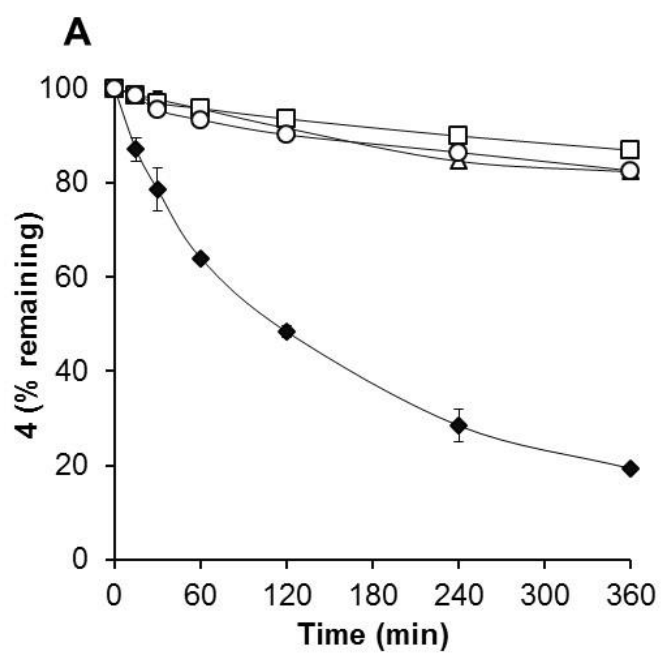

B
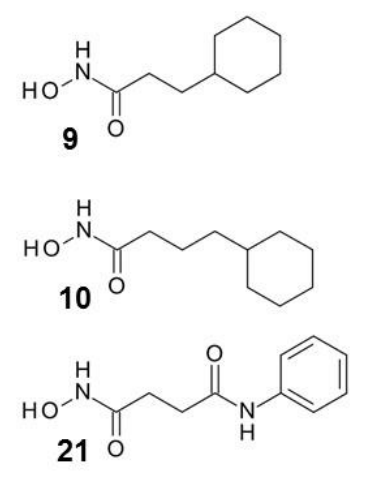

Figure 5 : Stabilization of 4 by highly unstable hydroxamic acids $\mathbf{9 , 1 0}$ and 21 . $^{\text {a }}$

a $\%$ of 4 remaining in the absence $(\checkmark)$ or presence of $9(\bigcirc), \mathbf{1 0}(\square), \mathbf{2 1}(\triangle)$.

As one of the $\mathrm{AChE}$ isoforms (isoform $\mathrm{E}$ ) is found anchored to erythrocytes, we checked for stability of hydroxamic acids in whole blood. No significant differences between plasma and whole blood stabilities were observed. This suggests that this isoform does not contribute significantly to the hydrolysis of hydroxamates.

As well, outside the plasma compartment, two isoforms of carboxylesterases are present in liver (CES1) and intestine (CES2) microsomes. We therefore checked for stability of compound $\mathbf{3}$ on microsomes in non-oxidative conditions. 3 that displays a half-life of $0.8 \mathrm{~h}$ in plasma is also very unstable in liver microsomes $\left(t_{1 / 2}=0.25 \mathrm{~h}\right)$ while stable on intestine microsomes $\left(t_{1 / 2}>6 \mathrm{~h}\right)$. This result suggests an implication of CES1 rather than CES2, in the hydrolysis of this compound. This implication of CES1 was further confirmed by the fact that $\mathbf{3}$ is hydrolyzed by both rodent and human CES1 isolated enzymes, like several other hydroxamic acids (Supplementary Table S2).

To draw general trends, we compared Box and Whisker plots for each physical-chemical parameters (Supplementary Figures S9-11) for substrates and non substrates of ArE, AChE and CES. No differences were evidenced for AChE and CES substrates. On the contrary, 
hydroxamic acids hydrolyzed by ArE display a cLogS and lower molecular weight and volume (Supplementary Figure S11). Because aryl esterase activity of plasma is not attributed to a specific enzyme, these results cannot be correlated with structural data.

\section{Discussion}

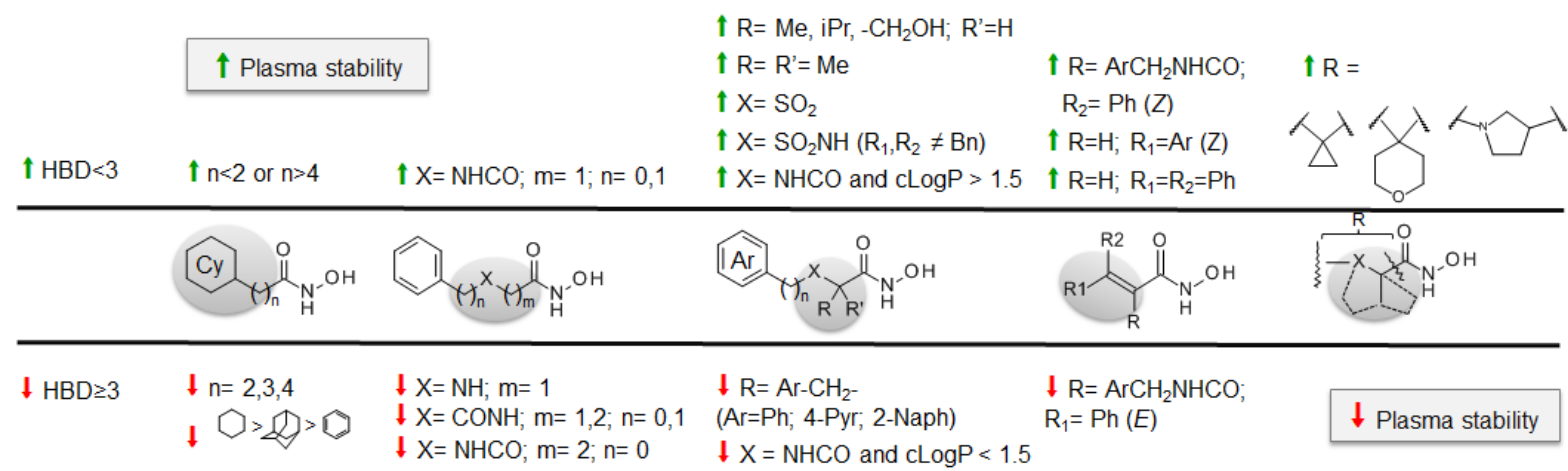

Figure 6 : Structure-Plasma Stability Relationships of hydroxamic acids: molecular properties and structural features increasing or decreasing stability.

Figure 6 summarizes Structure-Plasma Stability Relationships of hydroxamic acids. Regarding physical-chemical properties, $\mathrm{HBD}<3$ is beneficial for plasma stability. In the malonic series cLogP > 1.5 is deleterious for stability. Regarding structural features, combination of the nature or length of the linker with the hydrophobicity of the substituents is critical for stability. The presence of a tertiary carbon in $\alpha$-position, in a cycle like cyclopropyle or tetrahydropyrane, stabilizes compounds. Also, bigger substituents like sulfonamides in $\beta$ position are usually beneficial for stability. Hydroxamic acids bearing a double bond in this study, proved to be stable towards esterase hydrolysis. Absence of an aryl-methyl substituent, either constrained or not, in $\alpha$-position of the hydroxamic acid function, protects from hydrolysis.

\section{CES recognize $\alpha$-arylmethyl-substituted hydroxamic acids}

CES is the prominent esterase involved in the hydrolysis of all unstable compounds (Figure 4). The preference of carboxylesterases for hydroxamic acids that display an aryl- 
methyl group in $\alpha$-position was rationalized by docking of $\mathbf{3 3}, \mathbf{4 7}, \mathbf{5 1}$ in a model of rat CES1 (Figure 7). Catalytic Ser221 points towards the carbonyl of the hydroxamic acid, with distances and angles compatible with the hydrolysis (Supplementary methods). Interestingly, the arylmethyl group in $\alpha$-position interacts nicely with Phe304 and Phe318. Moreover, Phe 318 position shifts in function of the size and distance of the aromatic group. For example, with the naphthyl analogue 33, Phe 318 is pushed backwards, while for constrained analogue 51, it moves closer (Figure 7). Interaction with these Phe side chains helps better positioning in front of the catalytic Ser. Consistently, docking of compounds less sensitive to CES-mediated hydrolysis showed that the hydroxamic carbonyls are further away from the catalytic Ser221 due to the lack of aryl-methyl group in $\alpha$-position.

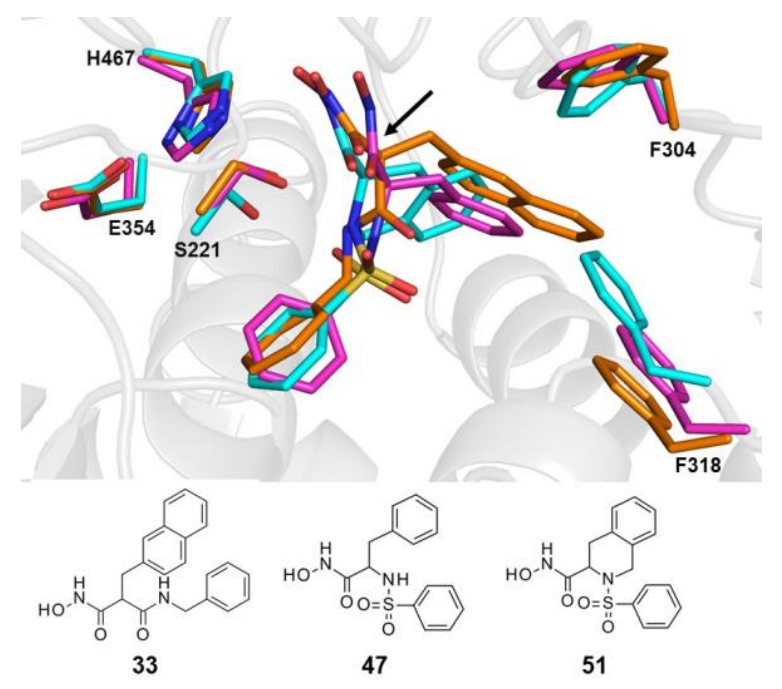

Figure 7 : Docking of 33, 47, 51 in rat CES1. ${ }^{a}$

${ }^{\text {a }}$ Carbon atoms for 33, 47 and $\mathbf{5 1}$ and key residues in orange, magenta and cyan respectively. Arrow points carbonyl group of the hydroxamic function.

Shifting or inverting an amide dramatically impact stability.

To understand why compound 20 was stable while close amide analogues 18,19 and 21 were not (Table 3), these four compounds were docked in both mAChE and in rCES (Supplementary Figure S6-S7). For example, hydroxamic acid $\mathbf{1 8}$ is stabilized within mAChE pocket by hydrogen bonds between the carbonyl of the hydroxamic acid function and the oxyanion hole, a hydrogen bond with Ser125 and a H- $\pi$ stacking to Tyr124. Similarly, the 
carbonyl of the hydroxamic function of $\mathbf{2 1}$ interacts with the oxyanion hole. An additional hydrogen bond between its amide function and Glu202, via a water molecule, is observed in the model. In comparison with $\mathbf{1 8}$ and $\mathbf{2 1}$, hydroxamic acid 19 makes fewer interactions with mAChE and the hydroxamic acid function is further away from the catalytic Ser203 $(2.45 \AA$ vs 2.24 A for 18, Supplementary Table S4). Finally, the stable hydroxamic acid 20, does not appear to make significant interactions with the catalytic site of mAChE. As a consequence, the carbonyl of the hydroxamic acid function is too far to allow the attack by Ser203 $(3.03 \AA$, Supplementary Figure S6 and Table S4). Similar results were obtained for rCES1 (Supplementary Figure S7). Binding of unstable hydroxamic acids $\mathbf{1 8}$ and $\mathbf{2 1}$ is driven by the interaction of the amide function with a water molecule in the vicinity of the oxyanion hole on one side, and $\pi$-stacking (parallel or T-shaped) with Phe304 and Phe318. Slightly more stable compound 19 is engaged in a $\mathrm{H}-\pi$ stacking with Leu255. In all these three cases, distances and angles to catalytic Ser221 are compatible with hydrolysis, in strong opposition with stable compound 20 (Supplementary Table S4). These results support the differences in stabilities for compounds 18-21 and corroborate the critical role of the amide position.

Plasma esterase activities differ between species.

All compounds of this study were shown to be stable in human plasma $\left(\mathrm{t}_{1 / 2}>6 \mathrm{~h}\right)$ with the exception of compound 21. This compound, though far more stable in human plasma $\left(\mathrm{t}_{1 / 2}=\right.$ $2.4 \mathrm{~h}$ ) than in rat plasma $\left(\mathrm{t}_{1 / 2}=0.43 \mathrm{~h}\right)$, is still rapidly hydrolyzed in human plasma (Table 3 ). The greater stability of hydroxamates in human plasma compared to rat plasma can be explained by both structural differences in the catalytic pockets (Supplementary Figure S2-S5), and relative concentrations and activities of the esterases between species.

Regarding cholinesterases, hAChE and $\mathrm{hBuChE}$ catalytic pockets are narrower than that of rodent $\mathrm{AChE}$ and $\mathrm{BuChE}$ (Supplementary Figure S5) respectively. Importantly, there is only 
a low concentration of $\mathrm{AChE}$ in human plasma, while BuChE is the most abundant esterase in human plasma ${ }^{40}$.

We showed for a representative set of hydroxamic acids sensitive to CES hydrolysis that they are substrates of both rodent and human enzymes (Supplementary Table S2), in spite of structural differences in catalytic pockets (Supplementary Figure S5 E and F respectively). While CES are the main esterases involved in rat plasma hydrolysis of hydroxamic acids, the fact that CES are the most abundant esterases in rodent plasma while they are absent in human plasma, explains the difference of stabilities in rat and human plasma. ${ }^{40}$ Moreover, because CES are present in liver and intestine microsomes, in both species, reducing the susceptibility of an hydroxamic acid to this enzyme is likely to have an impact on rodent plasma stability and human first-pass metabolism.

All the results obtained from this study can be used to guide the optimization of the plasma stability of hydroxamic acids. Some empirical rules are illustrated in Figure 8. For example, introduction of cyclic constrains, small $\alpha$-substituents, removal or shortening of $\alpha$ aryl-methyl groups improve stabilities, especially towards CES.

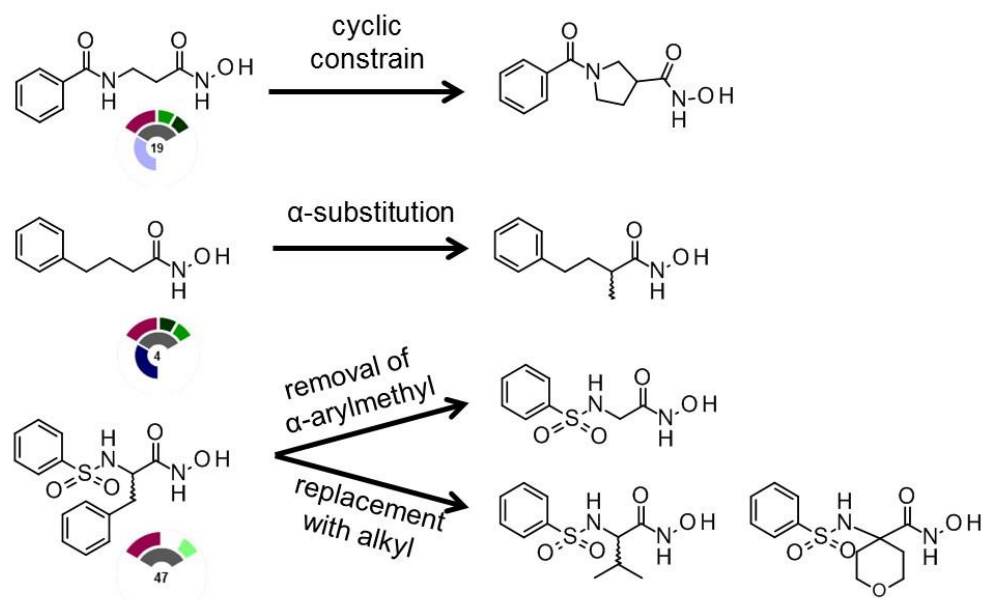

Figure 8 : Examples of the use of the medchem toolbox to stabilize hydroxamic acids.

\section{Conclusion}


We designed and synthesized a 57-member library of hydroxamic acids based on templates found in inhibitors of the main classes of Zinc metallohydrolases. This library was used to explore the Structure-Plasma Stability Relationships in chemical series relevant to the medicinal chemistry of this important class of therapeutic targets. In addition to including various chemical templates, the library covered a fair range of physical-chemical parameters (i.e. $137<\mathrm{MW}<410,-1.4<\log \mathrm{D}<3.4,49.3<\mathrm{tPSA}<113$ ).

Finding 1: at the exception of one compound, all hydroxamates were found to be very stable in human plasma. In contrast, many hydroxamates were unstable in rat plasma. This difference between species may pose a difficulty during preclinical development, as it may preclude systemic exposure and engagement of target in species used in toxicological studies.

Finding 2: Thanks to a deconvolution scheme that uses a series of inhibitors of increasing selectivity, we were able to determine which enzyme was responsible for the hydrolysis.

It appears that hydrolysis of unstable hydroxamates is performed by a limited number of plasma enzymes, mainly CES.

Finding 3: This limited number of enzymes have defined structural requirements, in contrast with the large variety promiscuous metabolic enzymes such as CYP450 and phase 2 enzymes that account for the majority of transformations performed on xenobiotics. It was thus possible to identified structural features that are beneficial or deleterious for plasma stability. We identified for example that aryl-methyl substituent in $\alpha$-position of the hydroxamic acid is well recognized by CES. Also, in linear amide-bearing compounds, the position and orientation of the amide bond relative to the hydroxamate is critical to recognition and stability: a NHCO in $\beta$-position of the hydroxamic function are stable while other amides are highly recognized by AChE and CES, leading to low stability. We also show that BuChE does not hydrolyze hydroxamic acids bearing a positive charge or bulky groups. 
In term of molecular properties, we saw that stable hydroxamates are found in the low range of $\log \mathrm{P}$, while a systematic multivariate analysis yielded a model where HBD $<3$ favors stability $(\mathrm{OR}=4.80)$.

As the hydroxamic acid function is often critical for the pharmacological activity, its replacement by isosters is often not possible. Also, stability in rodent plasma is essential to achieve proof-of-concept in animal, to assess secondary and safety pharmacology, and finally to estimate the safety window of drug candidates. Therefore a large difference in metabolic stability between human and preclinical species, especially when it involves transformation of a key element of pharmacophore can compromise developability of a drug candidate. Although the use of esterase inhibitors could partially restore adequate plasma concentration in animal models, these inhibitors have themselves side effects that could impede the interpretation of pharmacodynamic studies. In all, our study provides a toolbox that includes a validated protocol for hydroxamates stability testing, an esterase deconvolution procedure and SPSR that guide structural changes during optimization on the target of interest. It can help prioritizing hits and leads based on structural liabilities (templates and physical-chemical properties). This is the first comprehensive rule of thumb to obtain hydroxamic acids as stable in rodent as in human plasma, thus bridging the gap between species during preclinical development. 


\section{Experimental section}

\section{Chemistry.}

General Chemistry. Merck Millipore aluminum-backed sheets TLC silica gel $60 \mathrm{~F}_{254}$ were used for TLC. GraceResolv Cartridge columns (4 to 120 grams) were used to purify chemicals by flash column chromatography helped by Interchim Puriflash 430 equiped with evaporative light scattering detector (ELSD). ${ }^{1} \mathrm{H}$ and ${ }^{13} \mathrm{C}$ NMR were recorded at room temperature on a Bruker DPX 300 at 300 and $75 \mathrm{MHz}$, respectively. ${ }^{1} \mathrm{H}$ NMR spectra chemical shifts are in parts per million $(\mathrm{ppm})$ relative to the peak of DMSO-d 6 (2.50 ppm), $\mathrm{CD}_{3} \mathrm{OD}(3.31 \mathrm{ppm})$, or $\mathrm{CDCl}_{3}$ (7.26 ppm); ${ }^{13} \mathrm{C}$ NMR spectra chemical shifts are in parts per million (ppm) relative to the peak of $\mathrm{DMSO}_{6}(39.52 \pm 0.06 \mathrm{ppm}), \mathrm{CD}_{3} \mathrm{OD}(49.00 \pm 0.06 \mathrm{ppm})$, acetone- $d_{6}(2.05 \pm 0.06 \mathrm{ppm})$ or $\mathrm{CDCl}_{3}(77.16 \pm 0.06 \mathrm{ppm})$. Coupling constants $(J)$ are reported in hertz $(\mathrm{Hz})$ and peak multiplicities are reported as singlet (s), doublet (d), triplet (t), quadruplet (q), broad (br) and multiplet (m). Purity (\%) was measured by reverse-phase chromatography HPLC using UV detection $(215 \mathrm{~nm})$ and all final compounds showed purities greater than $95 \%$. Mass spectra were recorded on a LCMS system (Waters) composed of solvent manager 2695, photodiode array detector 2996, micromassZQ and a $\mathrm{C}_{18}$ Xbridge $3.5 \mu \mathrm{m}$ particle size HPLC column, dimensions 4.6 x $50 \mathrm{~mm}$. Analytical reverse phase HPLC gradient starting from $100 \%$ aqueous buffer $\mathrm{pH}=3.8 \pm 0.3\left(\mathrm{NH}_{4} \mathrm{OH} 0.01 \%, \mathrm{HCOOH} 0.02 \%\right)$ and reaching $100 \%$ acetonitrile buffer $\left(\mathrm{NH}_{4} \mathrm{OH} 0.01 \%, \mathrm{HCOOH} 0.02 \%\right)$ within $3.25 \mathrm{~min}$ at a flow rate of $2 \mathrm{~mL} / \mathrm{min}$ was used. When needed, compounds were purified by preparative HPLC on a LCMS Waters- 2 system composed of solvent manager 2545, dual wavelength absorbance detector 2487, 3100 single quadrupole mass detector and using a Xbridge ${ }^{\mathrm{TM}}$ prep $\mathrm{C}_{18} 5 \mu \mathrm{M}$ OBD $^{\mathrm{TM}}$ dimensions $50 \mathrm{~mm}$ x $250 \mathrm{~mm}$ column. Reverse phase preparative HPLC linear gradients started from $100 \%$ of aq. buffer $\mathrm{pH}$ $=3.8 \pm 0.3\left(\mathrm{NH}_{4} \mathrm{OH} 0.01 \%, \mathrm{HCOOH} 0.02 \%\right)$ or aq. buffer $\mathrm{pH}=9.2 \pm 0.3\left(\mathrm{NH}_{4} \mathrm{OH} 0.03 \%\right.$, $\mathrm{HCOOH} 0.01 \%$ ) and reached corresponding $100 \%$ acetonitrile buffer $\left(\mathrm{NH}_{4} \mathrm{OH} 0.01 \%\right.$, 
$\mathrm{HCOOH} 0.02 \%)$ or $\left(\mathrm{NH}_{4} \mathrm{OH} 0.03 \%, \mathrm{HCOOH} 0.01 \%\right)$ within 25 min at a flow rate of $80 \mathrm{~mL} /$ min. High-resolution mass spectrometry (HRMS) was measured with a quadrupole time-offlight (TOF) micromass Waters. Melting points were recorded on a Büchi melting point B-450. All commercial reagents and solvents were used without further purification. The synthesis of 37-38; $40-42$ has been previously described. $8^{\mathrm{a} ;} 24$

Highly toxic compound. Potassium cyanide extracted in aqueous phase was stirred and basified with $\mathrm{KOH} 15 \%(\mathrm{pH}$ has to be superior or equal to 14). Then sodium hypochlorite ( $\mathrm{NaClO}) 2.6 \%$ active chloride was added in very large excess (compared to the amount of potassium cyanide) and stirred at room temperature for $10 \mathrm{~min}$. Iodide strip was used to evaluate the oxidative potential of the mixture. A purple-blue color indicates a strong potential, allowing disposal of the treated phase in the adequate waste tank for destruction.

General procedure A for the synthesis of compounds $22 b, \mathbf{2 4 b}-\mathbf{2 6 b}, \mathbf{2 9 b}, \mathbf{4 6 b}-\mathbf{4 7 b}, \mathbf{5 5 b}$. Ester (1.00 mmol, 1.0 equiv) was dissolved in ethanol/THF (1:2) and aqueous $\mathrm{NaOH} 2 \mathrm{M}(13.00$ mmol, 13.0 equiv) was added. The solution was stirred at room temperature for $16 \mathrm{~h}$. $\mathrm{HCl} 1 \mathrm{~N}$ was added to bring the $\mathrm{pH}$ up to 2-3. The resulting mixture was extracted with dichloromethane. The organic layer was dried over $\mathrm{MgSO}_{4}$ and evaporated to give the corresponding carboxylic acid.

General procedure $\mathbf{B}$ for the synthesis of compounds 1-11, 13-14, 21-29, 46-49, 52-56. Commercial carboxylic acid (2.00 mmol, 1 equiv) and HOBt (2.20 mmol, 1.1 equiv) were dissolved in DMF (10 mL). A solution of EDCI.HCl $(2.70 \mathrm{mmol}, 1.5$ equiv) and $\mathrm{N}$ methylmorpholine $(6.01 \mathrm{mmol}, 3$ equiv) in DMF $(6.5 \mathrm{~mL})$ was slowly added to the previous solution cooled to $0{ }^{\circ} \mathrm{C}$. Then a solution of $O$-tritylhydroxylamine $(2.50 \mathrm{mmol}, 1.25$ equiv) in DMF (2.5 mL) was added. The mixture was stirred at room temperature overnight. The solvent was evaporated under reduced pressure and the residue was dissolved in DCM and washed two 
times with aqueous sat. $\mathrm{NaHCO}_{3}$ and two times with aqueous sat. $\mathrm{NH}_{4} \mathrm{Cl}$. The organic layer was dried over $\mathrm{MgSO}_{4}$, filtered and concentrated under reduced pressure to give the desired $O$ tritylhydroxamic acid. The corresponding $O$-tritylhydroxamic acid ( $1 \mathrm{mmol}, 1$ equiv) was dissolved in DCM $(9.50 \mathrm{~mL})$ and liquid TFA $(0.25 \mathrm{~mL})$ and triethylsilane $(0.25 \mathrm{~mL})$ were added. The mixture was stirred at room temperature for $30 \mathrm{~min}$. Solvents were removed under reduced pressure and the crude product was washed three times with pentane/diethyl ether 75:25 (v:v) affording a residue. The corresponding residue was purified by preparative HPLC using a linear acetonitrile/water (ammonium acetate/formic acid buffer, $\mathrm{pH}=3.8$ ) gradient (2:98 to 100:0 over $25 \mathrm{~min}$ ), for hydroxamic acids $\mathbf{3 - 4 , 9 - 1 0 , 1 4}$. Or the residue was washed with diethyl ether/petroleum ether (1:4) to give a crude product which was purified by flash silica gel column chromatography to give desired hydroxamic acid 1-2, 5-8, 11, 13, 21-29, 46-49, 5256.

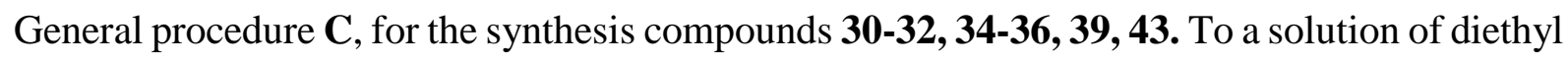
2-methylmalonate (3.56 mmol, 1 equiv) in ethanol absolute $(5 \mathrm{~mL}, 0.7 \mathrm{M})$ was added solid $\mathrm{KOH}$ (5.34 mmol, 1.5 equiv). This mixture was stirred for $24 \mathrm{~h}$ at room temperature before EtOH was evaporated in vacuo. The residue was dissolved in aqueous sat. $\mathrm{NaHCO}_{3}$ and washed with EtOAc. The aqueous phase was acidified to $\mathrm{pH}$ 1-2 with aqueous $\mathrm{HCl} 1 \mathrm{M}$. The desired carboxylic acid was extracted thrice with ethyl acetate, organic phases were pooled and evaporated to give pure carboxylic acid 63-68. To a solution of the appropriate carboxylic acid (2.70 mmol, 1 equiv) in anhydrous DMF $(6.60 \mathrm{~mL}, 0.5 \mathrm{M})$ at $0{ }^{\circ} \mathrm{C}$ were added HBTU (2.97 mmol, 1.1 equiv) and anhydrous DIPEA ( $8.1 \mathrm{mmol}, 3$ equiv). This mixture was stirred 5 min before benzylamine ( $2.83 \mathrm{mmol}, 1.05$ equiv) was added. The mixture was stirred $10 \mathrm{~min}$ at 0 ${ }^{\circ} \mathrm{C}$, and $4 \mathrm{~h} 30$ at room temperature. The solvent was evaporated under high vacuum and the crude product was partitioned between aqueous sat. $\mathrm{NaHCO}_{3}$ and EtOAc. The organic layer 
was washed 3 times with aqueous sat. $\mathrm{NaHCO}_{3}$, dried over $\mathrm{MgSO}_{4}$ and evaporated under vacuum. The residue was purified by flash silica gel column chromatography (cyclohexane/EtOAc 1:0 to 1:1 (v:v)), affording the corresponding ethyl 2-(benzylcarbamoyl)2-methylacetate 30a-32a, 34a-36a, 39a, 43a. To a solution of the latter (1.94 mmol, 1 equiv) in $\mathrm{MeOH}(4.31 \mathrm{~mL}, 0.45 \mathrm{M})$ was added a solution of aqueous hydroxylamine $50 \%(4.31 \mathrm{~mL})$ and $\mathrm{KCN}$ (0.012 g, $0.019 \mathrm{mmol}, 0.1$ equiv). The mixture was stirred $15 \mathrm{~h} 30 \mathrm{~min}$ at room temperature before it was concentrated under vacuum. The residue was partitioned between water and EtOAc (1:50, v:v). The organic layer was evaporated under vacuum and purified by preparative HPLC using a linear acetonitrile/water (ammonium-acetate/formic acid buffer, $\mathrm{pH}$ = 3.8) gradient, (2:98 to 100:0 over 25min). This afforded pure hydroxamic acids 30-32, 34-36, 39, 43.

Benzhydroxamic acid (1). Obtained following the general procedure B from benzoic acid. White solid (0.075 g, 17\%). Purity: $98 \%$. mp: $129^{\circ} \mathrm{C} . \mathrm{t}_{\mathrm{R}, \mathrm{LCMS}}=1.37 \mathrm{~min} . \mathrm{MS}(\mathrm{ESI}-): \mathrm{m} / \mathrm{z}=$ $136[\mathrm{M}-\mathrm{H}]^{-}, \mathrm{MS}(\mathrm{ESI}+): \mathrm{m} / z=138[\mathrm{M}+\mathrm{H}]^{+} .{ }^{1} \mathrm{H}$ NMR $300 \mathrm{MHz}\left(\mathrm{DMSO}-d_{6}\right) \delta(\mathrm{ppm}): 11.19(\mathrm{~s}$, 1H), $9.02(\mathrm{~s}, 1 \mathrm{H}), 7.74(\mathrm{dd}, J=1.5 \mathrm{~Hz}, J=7.5 \mathrm{~Hz}, 2 \mathrm{H}), 7.53-7.41(\mathrm{~m}, 3 \mathrm{H}) .{ }^{13} \mathrm{C} \mathrm{NMR} 75 \mathrm{MHz}$ $\left(\mathrm{DMSO}-d_{6}\right) \delta(\mathrm{ppm}): 164.1,132.8,131.1,128.3,126.8$. HRMS $\mathrm{m} / z$ calculated for $\mathrm{C}_{7} \mathrm{H}_{8} \mathrm{NO}_{2}$ $[\mathrm{M}+\mathrm{H}]^{+}:$138.0555. Found: 138.0566 .

2-Phenylethanehydroxamic acid (2). Obtained following the general procedure B from 2phenylacetic acid. Light brown solid (0.063 g, 13\%). Purity: $96 \%$. mp: $119^{\circ} \mathrm{C} \cdot \mathrm{t}_{\mathrm{R}, \mathrm{LCMS}}=1.52$ $\min$. MS (ESI-): $m / z=150[\mathrm{M}-\mathrm{H}]^{-}, \mathrm{MS}(\mathrm{ESI}+): m / z=152[\mathrm{M}+\mathrm{H}]^{+} .{ }^{1} \mathrm{H}$ NMR $300 \mathrm{MHz}(\mathrm{DMSO}-$ $\left.d_{6}\right) \delta(\mathrm{ppm}): 10.65(\mathrm{~s}, 1 \mathrm{H}), 8.81(\mathrm{~s}, 1 \mathrm{H}), 7.32-7.19(\mathrm{~m}, 5 \mathrm{H}), 3.27(\mathrm{~s}, 2 \mathrm{H}) .{ }^{13} \mathrm{C} \mathrm{NMR} 75 \mathrm{MHz}$ $\left(\mathrm{DMSO}-d_{6}\right) \delta(\mathrm{ppm}): 167.0,136.0,129.3,128.9,128.1,126.4,39.4$. HRMS $m / z$ calculated for $\mathrm{C}_{8} \mathrm{H}_{10} \mathrm{NO}_{2}[\mathrm{M}+\mathrm{H}]^{+}:$152.0712. Found: 152.0734 . 
3-Phenylpropanehydroxamic acid (3). Obtained following the general procedure $\mathbf{B}$. White solid $\left(0.084\right.$ g, 26\%). Purity $98 \% . \mathrm{mp}: 80{ }^{\circ} \mathrm{C} . \mathrm{t}_{\mathrm{R}, \mathrm{LCMS}}=1.76 \mathrm{~min} . \mathrm{MS}(\mathrm{ESI}-): \mathrm{m} / z=164[\mathrm{M}-\mathrm{H}]^{-}, \mathrm{MS}$ (ESI+): $m / z=166[\mathrm{M}+\mathrm{H}]^{+} .{ }^{1} \mathrm{H}$ NMR $300 \mathrm{MHz}\left(\mathrm{CDCl}_{3}\right) \delta(\mathrm{ppm}): 10.35(\mathrm{~s}, 1 \mathrm{H}), 8.70(\mathrm{~s}, 1 \mathrm{H})$, 7.29-7.14 (m, 5H), 2.82-2.78 (t, $J=7.5 \mathrm{~Hz}, 2 \mathrm{H}), 2.27-2.22(\mathrm{t}, J=7.5 \mathrm{~Hz}, 2 \mathrm{H}) .{ }^{13} \mathrm{C} \mathrm{NMR} 75$ $\mathrm{MHz}\left(\mathrm{CDCl}_{3}\right) \delta(\mathrm{ppm}): 171.1,140.3,128.8,128.4,126.7,34.9,31.5$. HRMS $m / z$ calculated for $\mathrm{C}_{9} \mathrm{H}_{12} \mathrm{NO}_{2}[\mathrm{M}+\mathrm{H}]^{+}:$166.0868. Found: 166.0882.

4-Phenylbutanehydroxamic acid (4). Obtained following the general procedure B. Brown oil $(0.176 \mathrm{~g}, 51 \%)$. Purity $95 \% . \mathrm{t}_{\mathrm{R}, \mathrm{LCMS}}=1.94 \mathrm{~min} . \mathrm{MS}(\mathrm{ESI}-): \mathrm{m} / z=178[\mathrm{M}-\mathrm{H}]^{-}, \mathrm{MS}(\mathrm{ESI}+): \mathrm{m} / \mathrm{z}$ $=180[\mathrm{M}+\mathrm{H}]^{+} .{ }^{1} \mathrm{H}$ NMR $300 \mathrm{MHz}\left(\mathrm{DMSO}-d_{6}\right) \delta(\mathrm{ppm}): 10.36(\mathrm{~s}, 1 \mathrm{H}), 8.69(\mathrm{br} \mathrm{s}, 1 \mathrm{H}), 7.31-$ $7.15(\mathrm{~m}, 5 \mathrm{H}), 2.57-2.55(\mathrm{t}, J=7.5 \mathrm{~Hz}, 2 \mathrm{H}), 1.99-1.94(\mathrm{t}, J=7.5 \mathrm{~Hz}, 2 \mathrm{H}), 1.83-1.73(\mathrm{~m}, 2 \mathrm{H})$. ${ }^{13} \mathrm{C}$ NMR 75 MHz (DMSO-d6) $\delta$ (ppm): 169.1, 141.9, 128.5, 126.0, 34.8, 32.0, 27.2. HRMS $m / z$ calculated for $\mathrm{C}_{10} \mathrm{H}_{14} \mathrm{NO}_{2}[\mathrm{M}+\mathrm{H}]^{+}:$180.1025. Found: 180.1049 .

5-Phenylpentanehydroxamic acid (5). Obtained following the general procedure B from 5phenylpentanoic acid. White solid $(0.036 \mathrm{~g}, 10 \%)$. Purity: $90 \%$. $\mathrm{mp}: 74{ }^{\circ} \mathrm{C} . \mathrm{t}_{\mathrm{R}, \mathrm{LCMS}}=2.47 \mathrm{~min}$. MS (ESI+): $m / z=194[\mathrm{M}+\mathrm{H}]^{+} .{ }^{1} \mathrm{H}$ NMR $300 \mathrm{MHz}$ (acetone- $\left.d_{6}\right) \delta(\mathrm{ppm}):$ 7.27-7.12 (m, 2H), 2.61-2.57 (m, 2H), 2.15-2.10 (m, 2H), 2.08-2.03 (m, 2H), 1.70-1.59 (m, 4H). ${ }^{13} \mathrm{C}$ NMR $75 \mathrm{MHz}$ (acetone- $\left.d_{6}\right) \delta(\mathrm{ppm}): 170.2,142.3,128.3,128.2,125.6,35.2,30.9,25.0$. HRMS $m / z$ calculated for $\mathrm{C}_{11} \mathrm{H}_{16} \mathrm{NO}_{2}[\mathrm{M}+\mathrm{H}]^{+}$: 194.1181. Found: 194.1180 .

6-Phenylhexanehydroxamic acid (6). Obtained following the general procedure B from 6phenylhexanoic acid. White solid (0.247 g, 45\%). Purity: $99 \% . \mathrm{mp}: 71^{\circ} \mathrm{C} \cdot \mathrm{t}_{\mathrm{R}, \mathrm{LCMS}}=2.72 \mathrm{~min}$. MS (ESI+): $m / z=208[\mathrm{M}+\mathrm{H}]^{+} .{ }^{1} \mathrm{H}$ NMR $300 \mathrm{MHz}\left(\mathrm{DMSO}-d_{6}\right) \delta(\mathrm{ppm}): 10.31(\mathrm{br} \mathrm{s}, 1 \mathrm{H}), 10.00$ 
(br s, 1H), 8.64 (br s, 1H), 7.28-7.13 (m, 5H), 2.57-2.49 (m, 7H), $1.92(\mathrm{t}, J=14.4 \mathrm{~Hz}, 2 \mathrm{H})$, 1.59-1.51 (m, 4H), 1.29-1.27 (m, 2H). ${ }^{13} \mathrm{C}$ NMR 75 MHz (DMSO-d6) $\delta(\mathrm{ppm}): 169.5,142.7$, $128.7,128.7,126.1,35.5,32.7,31.2,28.7,25.4$. HRMS $m / z$ calculated for $\mathrm{C}_{12} \mathrm{H}_{18} \mathrm{NO}_{2}[\mathrm{M}+\mathrm{H}]^{+}$: 208.1338. Found: 208.1334.

7-Phenylheptanehydroxamic acid (7). Obtained following the general procedure B from 7phenylheptanoic acid. White powder (0.060 g, 13\%). Purity 96\%. mp: $66{ }^{\circ} \mathrm{C} . \mathrm{t}_{\mathrm{R}, \mathrm{LCMS}}=2.97$ min. MS (ESI+): $m / z=222[\mathrm{M}+\mathrm{H}]^{+} .{ }^{1} \mathrm{H}$ NMR $300 \mathrm{MHz}\left(\right.$ acetone- $\left.d_{6}\right) \delta(\mathrm{ppm}):$ 7.27-7.11 (m, $5 \mathrm{H}), 2.58(\mathrm{t}, J=7.5 \mathrm{~Hz}, 2 \mathrm{H}), 2.09(\mathrm{t}, J=7.5 \mathrm{~Hz}, 2 \mathrm{H}), 1.62-1.55(\mathrm{~m}, 4 \mathrm{H}), 1.34-1.29(\mathrm{~m}, 4 \mathrm{H})$. ${ }^{13} \mathrm{C}$ NMR $75 \mathrm{MHz}$ (acetone- $\left.d_{6}\right) \delta(\mathrm{ppm}): 170.3,142.6,128.3,128.2,125.5,35.5,32.3,31.3$, 29.0, 25.3. HRMS m/z calculated for $\mathrm{C}_{13} \mathrm{H}_{20} \mathrm{NO}_{2}[\mathrm{M}+\mathrm{H}]^{+}:$222.1494. Found: 222.1494.

2-Cyclohexylethanehydroxamic acid (8). Obtained following the general procedure B from 2cyclohexylacetic acid. White solid $(0.107 \mathrm{~g}, 18 \%)$. Purity: $80 \% . \mathrm{mp}: 146^{\circ} \mathrm{C} . \mathrm{t}_{\mathrm{R}, \mathrm{LCMS}}=2.20 \mathrm{~min}$. MS (ESI+): $m / z=158[\mathrm{M}+\mathrm{H}]^{+} .{ }^{1} \mathrm{H}$ NMR $300 \mathrm{MHz}\left(\mathrm{DMSO}-d_{6}\right) \delta(\mathrm{ppm}): 10.31(\mathrm{br} \mathrm{s}, 1 \mathrm{H}), 8.64$ (br s, 1H), $1.81(\mathrm{~d}, J=6.3 \mathrm{~Hz}, 2 \mathrm{H}), 1.62(\mathrm{~d}, J=7.5 \mathrm{~Hz}, 6 \mathrm{H}), 1.20-1.06(\mathrm{~m}, 3 \mathrm{H}), 0.92-0.85(\mathrm{~m}$, 2H). ${ }^{13} \mathrm{C}$ NMR $75 \mathrm{MHz}\left(\mathrm{DMSO}-d_{6}\right) \delta$ (ppm): 168.6, 40.8, 34.9, 32.9, 26.3, 26.0. HRMS m/z calculated for $\mathrm{C}_{8} \mathrm{H}_{16} \mathrm{NO}_{2}[\mathrm{M}+\mathrm{H}]^{+}:$158.1181. Found: 158.1179 .

3-Cyclohexylpropanehydroxamic acid (9). Obtained following the general procedure B. Colorless oil $(0.072 \mathrm{~g}, 21 \%)$. Purity 99\%. $\mathrm{t}_{\mathrm{R}, \mathrm{LCMS}}=2.49 \mathrm{~min} . \mathrm{MS}(\mathrm{ESI}-): \mathrm{m} / z=170[\mathrm{M}-\mathrm{H}]^{-}$, MS (ESI+): $m / z=172[\mathrm{M}+\mathrm{H}]^{+} .{ }^{1} \mathrm{H}$ NMR $300 \mathrm{MHz}\left(\mathrm{DMSO}-d_{6}\right) \delta(\mathrm{ppm}): 1.96-1.91(\mathrm{t}, J=7.5$ $\mathrm{Hz}, 2 \mathrm{H}), 1.67-1.63(\mathrm{~m}, 5 \mathrm{H}), 1.41-1.33(\mathrm{~m}, 2 \mathrm{H}), 1.23-1.08(\mathrm{~m}, 4 \mathrm{H}), 0.88-0.78(\mathrm{q}, J=10.2 \mathrm{~Hz}$, 2H). ${ }^{13} \mathrm{C}$ NMR $75 \mathrm{MHz}$ (DMSO-d6) $\delta$ (ppm): 169.3, 36.5, 32.6, 32.5, 29.8, 26.1, 25.7. HRMS $m / z$ calculated for $\mathrm{C}_{9} \mathrm{H}_{18} \mathrm{NO}_{2}[\mathrm{M}+\mathrm{H}]^{+}:$172.1338. Found: 172.1354 . 
4-Cyclohexylbutanehydroxamic acid (10). Obtained following the general procedure B. White solid (0.034 g, 9\%). Purity 98\%. mp: $81^{\circ} \mathrm{C} . \mathrm{t}_{\mathrm{R}, \mathrm{LCMS}}=2.42 \mathrm{~min} . \mathrm{MS}(\mathrm{ESI}-): \mathrm{m} / \mathrm{z}=184[\mathrm{M}-\mathrm{H}]^{-}$, MS (ESI+): $m / z=186[\mathrm{M}+\mathrm{H}]^{+} .{ }^{1} \mathrm{H}$ NMR $300 \mathrm{MHz}\left(\mathrm{DMSO}-d_{6}\right) \delta(\mathrm{ppm}): 10.28(\mathrm{br} \mathrm{s}, 1 \mathrm{H}), 8.63$ (br s, $1 \mathrm{H}), 1.89(\mathrm{t}, J=7.5 \mathrm{~Hz}, 2 \mathrm{H}), 1.66-1.62(\mathrm{~m}, 5 \mathrm{H}), 1.53-1.42$ (quin, $J=7.5 \mathrm{~Hz}, 2 \mathrm{H}), 1.24-$ $1.06(\mathrm{~m}, 6 \mathrm{H}), 0.88-0.77(\mathrm{~m}, 2 \mathrm{H}) .{ }^{13} \mathrm{C}$ NMR $75 \mathrm{MHz}$ (DMSO-d $) \delta(\mathrm{ppm}): 169.1,36.8,36.4$, 32.8, 32.5, 26.2, 25.8, 22.5. HRMS $m / z$ calculated for $\mathrm{C}_{10} \mathrm{H}_{20} \mathrm{NO}_{2}[\mathrm{M}+\mathrm{H}]^{+}:$186.1494. Found: 186.1517.

2-(1-Adamantyl)ethanehydroxamic acid (11). Obtained following the general procedure $\mathbf{B}$ from 2-(adamantan-1-yl)acetic acid. White solid (0.120 g, 48\%). Purity 99\%. mp: $173{ }^{\circ} \mathrm{C} \cdot \mathrm{t}_{\mathrm{R}, \mathrm{LCMS}}=$ $2.63 \mathrm{~min} . \mathrm{MS}(\mathrm{ESI}+): \mathrm{m} / z=210[\mathrm{M}+\mathrm{H}]{ }^{+} .{ }^{1} \mathrm{H}$ NMR $300 \mathrm{MHz}\left(\mathrm{DMSO}-d_{6}\right) \delta(\mathrm{ppm}): 10.20(\mathrm{br} \mathrm{s}$, 1H), 1.90 (s, 3H), 1.68-1.54 (m, 14H). ${ }^{13} \mathrm{C}$ NMR 75 MHz (DMSO-d6) $\delta(p p m): ~ 167.2,47.1$, 42.5, 36.9, 32.6, 28.5. HRMS $m / z$ calculated for $\mathrm{C}_{12} \mathrm{H}_{20} \mathrm{NO}_{2}[\mathrm{M}+\mathrm{H}]^{+}$: 210.1494. Found: 210.1507.

3-(1-Adamantyl)propanehydroxamic acid (12). To a solution of 2-(1-adamantyl)ethanol (1.984 g, $11 \mathrm{mmol}, 1$ equiv) in pyridine $(13.7 \mathrm{~mL}, 0.8 \mathrm{M})$ was added 4-methylbenzenesulfonyl chloride (2.098 $\mathrm{g}, 11 \mathrm{mmol}, 1$ equiv) and the resulting yellow mixture was stirred $20 \mathrm{~h}$ at room temperature. Pyridine was evaporated under vacuum and the crude product was dissolved in EtOAc. The organic phase was washed twice with $1 \mathrm{~N} \mathrm{HCl}$ then twice with aqueous sat. $\mathrm{NaHCO}_{3}$, dried over $\mathrm{MgSO}_{4}$, filtered and concentrated to afford 2-(1-adamantyl)ethyl 4methylbenzenesulfonate $(3.003 \mathrm{~g}, 75 \%)$ as a colorless oil. Purity $91 \% . \mathrm{t}_{\mathrm{R}, \mathrm{LCMS}}=3.95 \mathrm{~min} . \mathrm{MS}$ $(\mathrm{ESI}+): m / z=357[\mathrm{M}+\mathrm{Na}]^{+} .{ }^{1} \mathrm{H} \mathrm{NMR} 300 \mathrm{MHz}\left(\mathrm{DMSO}-d_{6}\right) \delta(\mathrm{ppm}): 7.79(\mathrm{~d}, J=8.3 \mathrm{~Hz}, 2 \mathrm{H})$, $7.48(\mathrm{~d}, J=8.3 \mathrm{~Hz}, 2 \mathrm{H}), 4.05(\mathrm{t}, J=6.9 \mathrm{~Hz}, 2 \mathrm{H}), 2.42(\mathrm{~s}, 3 \mathrm{H}), 1.85(\mathrm{~s}, 3 \mathrm{H}), 1.63-1.49(\mathrm{~m}, 8 \mathrm{H})$, 
1.37-1.33 (m, 8H). ${ }^{13} \mathrm{C}$ NMR 75 MHz (DMSO-d6) $\delta(p p m): ~ 144.8, ~ 132.4,130.1,127.6,67.4$, $41.8,41.5,36.3,31.2,27.8,21.0$. To a solution of this tosylate $(2.342 \mathrm{~g}, 7.00 \mathrm{mmol}, 1$ equiv) in DMF (8.75 mL, 0.8 M) wad added $\mathrm{KCN}(0.911 \mathrm{~g}, 14.00 \mathrm{mmol}, 2$ equiv). The resulting suspension was stirred at $80{ }^{\circ} \mathrm{C}$ for $15 \mathrm{~h}$. It was diluted with water and extracted with $\mathrm{Et}_{2} \mathrm{O}$. The combined organic phases were washed with water and brine, dried over $\mathrm{MgSO}_{4}$ and concentrated in vacuo to give $1.126 \mathrm{~g}$ of a yellow oil. This crude product was purified by flash silica gel column chromatography (cyclohexane/ethyl acetate, 90:10 to 70:30). Pure 3-(1adamantyl)propanenitrile $58(1.126 \mathrm{~g}, 84 \%)$ was obtained as yellow needle crystals. No signal by LCMS. ${ }^{1} \mathrm{H}$ NMR $300 \mathrm{MHz}\left(\mathrm{DMSO}-d_{6}\right) \delta(\mathrm{ppm}): 2.40(\mathrm{t}, J=8.0 \mathrm{~Hz}, 2 \mathrm{H}), 1.92$ (br s, 3H), $1.62($ br q, $J=12.3 \mathrm{~Hz}, 6 \mathrm{H}), 1.44(\mathrm{~d}, J=2.5 \mathrm{~Hz}, 6 \mathrm{H}), 1.36(\mathrm{t}, J=8.0 \mathrm{~Hz}, 3 \mathrm{H}) .{ }^{13} \mathrm{C} \mathrm{NMR} 75$ $\mathrm{MHz}\left(\mathrm{DMSO}-d_{6}\right) \delta(\mathrm{ppm}): 121.6,40.9,36.6,31.7,27.8,10.2$. To a solution of $\mathbf{5 8}(0.869 \mathrm{~g}, 4.59$ mmol, 1 equiv) in $\mathrm{EtOH}(9.20 \mathrm{~mL}, 0.5 \mathrm{M})$ was added a solution of $\mathrm{KOH}(0.901 \mathrm{~g}, 16.07 \mathrm{mmol}$, 3.5 equiv) in $\mathrm{H}_{2} \mathrm{O}(9.20 \mathrm{~mL}, 1.75 \mathrm{M})$. The mixture was heated to $90{ }^{\circ} \mathrm{C}$ for $20 \mathrm{~h}$. Solvents were evaporated in vacuo then the residue was dissolved in aqueous $\mathrm{HCl} 1 \mathrm{M}$ and EtOAc. The organic phase was washed three times with $\mathrm{HCl} 1 \mathrm{M}$, once with brine and dried over $\mathrm{MgSO}_{4}$. EtOAc was evaporated in vacuo affording 3-(1-adamantyl)propanoic acid (0.942 g, 97\%) as white crystals. TLC cyclohexane/EtOAc 70:30 (v:v) $\mathrm{R}_{f}=0.5$. To a solution of this acid $(0.309 \mathrm{~g}, 1.48$ mmol, 1 equiv) in anhydrous methanol $(5 \mathrm{~mL}, 0.33 \mathrm{M})$ cooled to $0{ }^{\circ} \mathrm{C}$ was added dropwise thionyl chloride $(0.323 \mathrm{~mL}, 4.45 \mathrm{mmol}, 3$ equiv). The reaction was stirred at room temperature for 4 h 30 min before solvents were evaporated under vacuum. White crystals were obtained which were dissolved in EtOAc (a white precipitate appear) and washed with aqueous $\mathrm{NaHCO}_{3}$ $5 \%$ (The white precipitate disappear when aqueous phase was added). The crude product methyl 3-(1-adamantyl)propanoate 12a was obtained as a white powder $(0.071 \mathrm{~g}, 21 \%)$ by evaporating the solvent and was used in the next step without further purification. TLC cyclohexane/EtOAc 70:30 (v:v) $\mathrm{R}_{f}=0.90$. To a solution of $\mathbf{1 2 a}(0.071 \mathrm{~g}, 0.31 \mathrm{mmol}, 1$ equiv) in $\mathrm{MeOH}(0.700 \mathrm{~mL}$, 
$0.45 \mathrm{M})$ was added a solution of aqueous hydroxylamine $50 \%(0.700 \mathrm{~mL})$ before $\mathrm{KCN}(0.02 \mathrm{~g}$, $0.028 \mathrm{mmol}, 0.1$ equiv). The mixture was stirred $12 \mathrm{~h} 30 \mathrm{~min}$ at room temperature. It was concentrated under vacuum and an aqueous workup was performed using $\mathrm{H}_{2} \mathrm{O} / \mathrm{EtOAc}$ (1:50 $(\mathrm{v}: \mathrm{v}))$. The organic layer was evaporated under vacuum and purified by preparative HPLC using a linear acetonitrile/water (ammonium-acetate/formic acid buffer, $\mathrm{pH}=9.2$ ) gradient $(2: 98$ to 100:0 over 25min) affording 3-(1-adamantyl)propanehydroxamic acid $\mathbf{1 2}$ as a white powder (0.026 g, 36\%). Purity 99\%. mp: $153^{\circ} \mathrm{C}$. TLC cyclohexane/EtOAc 70:30 (v:v) $\mathrm{R}_{f}=0.50 . \mathrm{t}_{\mathrm{R}, \mathrm{LCMS}}$ $=2.57 \mathrm{~min} . \mathrm{MS}(\mathrm{ESI}-): \mathrm{m} / z=222[\mathrm{M}-\mathrm{H}]^{-}, \mathrm{MS}(\mathrm{ESI}+): m / z=224[\mathrm{M}+\mathrm{H}]^{+} .{ }^{1} \mathrm{H} \mathrm{NMR} 300 \mathrm{MHz}$ $\left(\mathrm{CD}_{3} \mathrm{OD}-d_{4}\right) \delta(\mathrm{ppm}): 10.31(\mathrm{~s}, 1 \mathrm{H}), 8.62(\mathrm{~d}, J=1.2 \mathrm{~Hz}, 1 \mathrm{H}), 1.91-1.85(\mathrm{~m}, 5 \mathrm{H}), 1.61(\mathrm{q}, J=$ $12.1 \mathrm{~Hz}, 6 \mathrm{H}), 1.41(\mathrm{~d}, J=2.1 \mathrm{~Hz}, 6 \mathrm{H}), 1.25(\mathrm{td}, J=5.4 \mathrm{~Hz}, J=2.8 \mathrm{~Hz}, 2 \mathrm{H}) .{ }^{13} \mathrm{C} \mathrm{NMR} 75 \mathrm{MHz}$ $\left(\mathrm{CD}_{3} \mathrm{OD}-d_{4}\right) \delta(\mathrm{ppm}): 169.8,41.5,36.5,31.6,27.9,26.0$. HRMS $m / z$ calculated for $\mathrm{C}_{13} \mathrm{H}_{22} \mathrm{NO}_{2}$ $[\mathrm{M}+\mathrm{H}]^{+}:$224.1651. Found: 224.1664.

2-(Benzylamino)ethanehydroxamic acid (13). Obtained following the general procedure $\mathbf{B}$ from N-benzylglycine hydrochloride. White powder $(0.070$ g, $25 \%)$. Purity $99 \%$. mp: $169^{\circ} \mathrm{C}$. $\mathrm{t}_{\mathrm{R}, \mathrm{LCMS}}$ $=1.47 \mathrm{~min} . \mathrm{MS}(\mathrm{ESI}+): \mathrm{m} / z=181[\mathrm{M}+\mathrm{H}]^{+} .{ }^{1} \mathrm{H}$ NMR $300 \mathrm{MHz}\left(\mathrm{DMSO}-d_{6}\right) \delta(\mathrm{ppm}): 10.94(\mathrm{br}$ s, $1 \mathrm{H}), 9.31$ (br s, 1H), 9.26 (br s, $1 \mathrm{H}), 7.45-7.42(\mathrm{~m}, 5 \mathrm{H}), 4.16(\mathrm{~s}, 2 \mathrm{H}), 3.55(\mathrm{~s}, 2 \mathrm{H}) .{ }^{13} \mathrm{C} \mathrm{NMR}$ $75 \mathrm{MHz}\left(\mathrm{DMSO}-d_{6}\right) \delta(\mathrm{ppm}): 162.2,131.9,130.5,129.5,129.2,50.4,45.2 . \mathrm{HRMS} \mathrm{m} / \mathrm{z}$ calculated for $\mathrm{C}_{9} \mathrm{H}_{13} \mathrm{~N}_{2} \mathrm{O}_{2}[\mathrm{M}+\mathrm{H}]^{+}:$181.0972. Found: 181.0977 .

$\mathrm{N}$-[2-(Hydroxyamino)-2-oxo-ethyl]benzamide (14). Obtained following the general procedure B. White solid (0.008 g, 5\%). Purity $97 \%$. mp: $149{ }^{\circ} \mathrm{C} . \mathrm{t}_{\mathrm{R}, \mathrm{LCMS}}=1.43 \mathrm{~min}$. MS (ESI-): $\mathrm{m} / \mathrm{z}=$ $193[\mathrm{M}-\mathrm{H}]^{-}, \mathrm{MS}(\mathrm{ESI}+): m / z=195[\mathrm{M}+\mathrm{H}]^{+} .{ }^{1} \mathrm{H}$ NMR $300 \mathrm{MHz}\left(\mathrm{CD}_{3} \mathrm{OD}-d_{4}\right) \delta(\mathrm{ppm}): 7.88-$ $7.85(\mathrm{dd}, J=0.9 \mathrm{~Hz}, J=8.1 \mathrm{~Hz}, 2 \mathrm{H}), 7.54(\mathrm{tt}, J=0.9 \mathrm{~Hz}, J=7.5 \mathrm{~Hz}, 1 \mathrm{H}), 7.46(\mathrm{td}, J=7.5 \mathrm{~Hz}$, $J=8.1 \mathrm{~Hz}, 2 \mathrm{H}), 3.99(\mathrm{~s}, 2 \mathrm{H}) .{ }^{13} \mathrm{C} \mathrm{NMR} 75 \mathrm{MHz}\left(\mathrm{CD}_{3} \mathrm{OD}-d_{4}\right) \delta(\mathrm{ppm}): 170.7,169.1,135.2$ 
133.1, 129.8, 128.7, 42.1. HRMS $m / z$ calculated for $\mathrm{C}_{9} \mathrm{H}_{11} \mathrm{~N}_{2} \mathrm{O}_{3}[\mathrm{M}+\mathrm{H}]^{+}$: 195.0770. Found: 195.0799.

3-(Hydroxyamino)-3-oxo-N-phenyl-propanamide (15). A solution of commercial Meldrum's acid (0.332 g, $2.30 \mathrm{mmol}, 1$ equiv) and aniline $(0.631 \mathrm{~mL}, 6.91 \mathrm{mmol}, 3$ equiv) in $\mathrm{MeCN}$ (1.85 $\mathrm{mL}, 1.25 \mathrm{M}$ ) was stirred for $2 \mathrm{~h}$ at $80{ }^{\circ} \mathrm{C}$. The mixture was evaporated under vacuum and the residue was partitioned between aqueous sat. $\mathrm{NaHCO}_{3}$ and EtOAc. The aqueous phase was acidified to $\mathrm{pH}$ 1-2 with $\mathrm{HCl} 1 \mathrm{M}$ and extracted with ethyl acetate. Solvents were evaporated under reduced pressure to afford 3-anilino-3-oxo-propanoic acid $\mathbf{1 5 b}(0.202 \mathrm{~g}, 48 \%)$ as white crystals. $\mathrm{t}_{\mathrm{R}, \mathrm{LCMS}}=1.60 \mathrm{~min} . \mathrm{MS}(\mathrm{ESI}-): \mathrm{m} / z=178[\mathrm{M}-\mathrm{H}]^{-}, \mathrm{MS}(\mathrm{ESI}+): \mathrm{m} / z=180[\mathrm{M}+\mathrm{H}]^{+}$. Caution: a 40\% rate of degradation was observed after 3 days at room temperature (brown color appears on crystals). Impure carboxylic acid $\mathbf{1 5 b}(0.202 \mathrm{~g}, 1.12 \mathrm{mmol}, 1$ equiv) was solubilized in anhydrous $\mathrm{MeOH}(3.5 \mathrm{~mL}, 0.32 \mathrm{M})$ at $0{ }^{\circ} \mathrm{C}$. $\mathrm{SOCl}_{2}(0.246 \mathrm{~mL}, 3.38 \mathrm{mmol}, 3$ equiv) was added dropwise and the mixture was stirred for $1 \mathrm{~h}$ at room temperature. The mixture was dissolved in EtOAc $(10 \mathrm{~mL})$ and water $(20 \mathrm{~mL})$. The aqueous phase was extracted twice with EtOAc, organic phases were pooled, dried over $\mathrm{MgSO}_{4}$ and evaporated under vacuum, affording Methyl 3-anilino-3-oxo-propanoate 15a as a white powder $(0.189 \mathrm{~g}, 43 \%)$ with a purity of only $50 \%$. 15a was anyway used in the final step without further purification. $t_{R, L C M S}$ $=2.02 \mathrm{~min} . \mathrm{MS}(\mathrm{ESI}-): \mathrm{m} / z=192[\mathrm{M}-\mathrm{H}]^{-}, \mathrm{MS}(\mathrm{ESI}+): \mathrm{m} / z=194[\mathrm{M}+\mathrm{H}]^{+}$. To a solution of $15 \mathbf{a}$ (0.189 g, $0.98 \mathrm{mmol}, 1$ equiv) in $\mathrm{MeOH}(4 \mathrm{~mL}, 0.25 \mathrm{M})$ was added a solution of aqueous hydroxylamine $50 \%(4 \mathrm{~mL}$,$) and \mathrm{KCN}(0.032 \mathrm{~g}, 0.49 \mathrm{mmol}, 0.5$ equiv). The solution was stirred overnight at room temperature. It was concentrated under vacuum and an aqueous workup was performed using $\mathrm{H}_{2} \mathrm{O} /$ EtOAc (1:50 (v:v)). The organic layer was evaporated under vacuum and purified by preparative HPLC using a linear acetonitrile/water (ammoniumacetate/formic acid buffer, $\mathrm{pH}=3.8$ ) gradient (2:98 to 100:0 over $25 \mathrm{~min}$ ), affording the 
hydroxamic acid 15 as a white powder $(0.015 \mathrm{~g}, 8 \%)$. Purity $96 \%$. mp: $149{ }^{\circ} \mathrm{C} . \mathrm{t}_{\mathrm{R}, \mathrm{LCMS}}=1.55$ min. MS (ESI-): $m / z=193[\mathrm{M}-\mathrm{H}]^{-}, \mathrm{MS}(\mathrm{ESI}+): m / z=195[\mathrm{M}+\mathrm{H}]^{+} .{ }^{1} \mathrm{H}$ NMR $300 \mathrm{MHz}(\mathrm{DMSO}-$ $\left.d_{6}\right) \delta(\mathrm{ppm}): 10.10(\mathrm{~s}, 1 \mathrm{H}), 7.59-7.56(\mathrm{~m}, 2 \mathrm{H}), 7.30(\mathrm{t}, J=7.4 \mathrm{~Hz}, 2 \mathrm{H}), 7.04(\mathrm{t}, J=7.4 \mathrm{~Hz}, 1 \mathrm{H})$, $3.11(\mathrm{~s}, 2 \mathrm{H}) .{ }^{13} \mathrm{C}$ NMR $75 \mathrm{MHz}$ (DMSO-d $\left.d_{6}\right) \delta(\mathrm{ppm}): 165.5,163.6,138.9,128.7,123.4,119.0$, 42.0. HRMS $m / z$ calculated for $\mathrm{C}_{9} \mathrm{H}_{11} \mathrm{~N}_{2} \mathrm{O}_{3}[\mathrm{M}+\mathrm{H}]^{+}:$195.0770. Found: 195.0801 .

2-(2-Phenylethylamino)ethanehydroxamic acid (16). To a solution of 2-phenylethanamine (0.162 g, $1.33 \mathrm{mmol}, 1$ equiv) and anhydrous DIPEA ( $0.244 \mathrm{~mL}, 1.40 \mathrm{mmol}, 1.05$ equiv) in anhydrous DMF $(2.40 \mathrm{~mL}, 0.55 \mathrm{M})$ at $0{ }^{\circ} \mathrm{C}$ was added dropwise methyl 2-bromoacetate $(0.123$ $\mathrm{mL}, 1.33 \mathrm{mmol}, 1$ equiv). The mixture was stirred for $1 \mathrm{~h}$ at $0{ }^{\circ} \mathrm{C}$ and $3 \mathrm{~h}$ at room temperature. Solvents were evaporated in vасио and the brown crude product was purified by flash silica gel column chromatography (cyclohexane/EtOAc, 100:0 to 30:70) affording methyl 2-(2phenylethylamino)acetate $(\mathbf{1 6 a})$ as a colorless oil $(0.146 \mathrm{~g}, 54 \%) . \mathrm{t}_{\mathrm{R}, \mathrm{LCMS}}=1.65 \mathrm{~min}$. MS $(\mathrm{ESI}+): \mathrm{m} / z=194[\mathrm{M}+\mathrm{H}]^{+}$. To a solution of $\mathbf{1 6 a}(0.086 \mathrm{~g}, 0.44 \mathrm{mmol}, 1$ equiv $)$ in $\mathrm{MeOH}(0.490$ $\mathrm{mL} ; 0.45 \mathrm{M})$ was added a solution of aqueous hydroxylamine $50 \%(4.90 \mathrm{~mL})$ and $\mathrm{KCN}(0.003$ g, $0.05 \mathrm{mmol}, 0.1$ equiv). The mixture was stirred for $3 \mathrm{~h} 30 \mathrm{~min}$ at room temperature. It was concentrated under vacuum and an aqueous workup was performed using $\mathrm{H}_{2} \mathrm{O} / \mathrm{EtOAc}$ (1:50 (v:v)). The organic layer was evaporated under vacuum and purified by preparative HPLC using a linear acetonitrile/water (ammonium-acetate/formic acid buffer $\mathrm{pH}=9.2$ ) gradient (2:98 to 100:0 over $25 \mathrm{~min})$, affording the hydroxamic acid 16 as a white powder $(0.032 \mathrm{~g}, 36 \%)$. Purity 98\%. $\mathrm{mp}: 146{ }^{\circ} \mathrm{C} \cdot \mathrm{t}_{\mathrm{R}, \mathrm{LCMS}}=1.47 \mathrm{~min} . \mathrm{MS}(\mathrm{ESI}-): \mathrm{m} / z=193[\mathrm{M}-\mathrm{H}]^{-}, \mathrm{MS}(\mathrm{ESI}+): \mathrm{m} / z=195$ $[\mathrm{M}+\mathrm{H}]^{+} .{ }^{1} \mathrm{H}$ NMR $300 \mathrm{MHz}\left(\mathrm{DMSO}-d_{6}\right) \delta(\mathrm{ppm}):$ 7.30-7.14 (m, 5H), 3.03 (s, 2H), $2.68(\mathrm{~s}, 4 \mathrm{H})$. ${ }^{13} \mathrm{C}$ NMR 75 MHz (DMSO-d6) $\delta$ (ppm): 167.8, 140.2, 128.5, 128.2, 125.8, 50.5, 49.8, 35.7. HRMS $m / z$ calculated for $\mathrm{C}_{10} \mathrm{H}_{15} \mathrm{~N}_{2} \mathrm{O}_{2}[\mathrm{M}+\mathrm{H}]^{+}:$195.1134. Found: 195.1140. 
3-(Benzylamino)propanehydroxamic acid (17). To a solution of methyl prop-2-enoate $(0.316$ $\mathrm{mL}, 3.48 \mathrm{mmol}, 1$ equiv) in ethanol $(1.70 \mathrm{~mL}, 2 \mathrm{M})$ was added benzylamine $(0.381 \mathrm{~mL}, 3.48$ mmol, 1 equiv) and the mixture was stirred for $18 \mathrm{~h}$ at room temperature. The crude product was purified by flash silica gel column chromatography (DCM/MeOH, 100:0 to 90:10) affording methyl 3-(benzylamino)propanoate $17 \mathbf{a}(0.603 \mathrm{~g}, 84 \%)$ as a colorless oil. Purity $94 \%$. $\mathrm{t}_{\mathrm{R}, \mathrm{LCMS}}=1.47 \mathrm{~min} . \mathrm{MS}(\mathrm{ESI}+): \mathrm{m} / z=194[\mathrm{M}+\mathrm{H}]^{+}$. To a solution of 17a $(0.603 \mathrm{~g}, 3.12 \mathrm{mmol}$, 1 equiv) in methanol $(6.80 \mathrm{~mL}, 0.45 \mathrm{M})$ was added a solution of aqueous hydroxylamine $50 \%$ $(6.80 \mathrm{~mL})$ and $\mathrm{KCN}(0.02 \mathrm{~g}, 0.28 \mathrm{mmol}, 0.1$ equiv). The mixture was stirred for $3 \mathrm{~h} 30 \mathrm{~min}$ at room temperature. It was then concentrated under vacuum and an aqueous workup was performed using $\mathrm{H}_{2} \mathrm{O} /$ EtOAc $(1: 50(\mathrm{v}: \mathrm{v}))$. The organic layer was evaporated under vacuum and purified by flash column chromatography (DCM/MeOH, 100:0 to 85:15) affording the hydroxamic acid 17 as white crystals $(0.097 \mathrm{~g}, 15 \%)$. Purity $99 \% . \mathrm{mp}: 118{ }^{\circ} \mathrm{C} \cdot \mathrm{t}_{\mathrm{R}, \mathrm{LCMS}}=1.17$ min. MS (ESI-): $m / z=193[\mathrm{M}-\mathrm{H}]^{-}, \mathrm{MS}(\mathrm{ESI}+): \mathrm{m} / z=195[\mathrm{M}+\mathrm{H}]^{+} .{ }^{1} \mathrm{H}$ NMR $300 \mathrm{MHz}(\mathrm{DMSO}-$ $\left.d_{6}\right) \delta(\mathrm{ppm}): 7.30(\mathrm{~m}, 4 \mathrm{H}), 7.22(\mathrm{~m}, 1 \mathrm{H}), 3.66(\mathrm{~s}, 2 \mathrm{H}), 2.67(\mathrm{t}, J=6.9 \mathrm{~Hz}, 2 \mathrm{H}), 2.12(\mathrm{t}, J=6.9$ $\mathrm{Hz}, 2 \mathrm{H}) .{ }^{13} \mathrm{C}$ NMR $75 \mathrm{MHz}$ (DMSO- $d_{6}$ ) $\delta$ (ppm): 168.3, 140.8, 128.1, 127.9, 126.5, 52.7, 45.0, 33.0. HRMS $m / z$ calculated for $\mathrm{C}_{10} \mathrm{H}_{15} \mathrm{~N}_{2} \mathrm{O}_{2}[\mathrm{M}+\mathrm{H}]^{+}$: 195.1134. Found: 195.1140 .

N-Hydroxycarbamoylmethyl-2-phenyl-acetamide (18). To a solution of hydroxylamine hydrochloride (2.12 g, $30.57 \mathrm{mmol}, 7$ equiv) in $\mathrm{MeOH}(35 \mathrm{~mL})$ was added $\mathrm{KOH}$ (2.70 g, 48.0 mmol, 11 equiv). The mixture was stirred $30 \mathrm{~min}$ at room temperature. This solution was then filtered and added to a solution of methyl 2-(2-phenylacetamido)acetate 18a (0.905 g, 4.37 mmol, 1 equiv) in $\mathrm{MeOH}(25 \mathrm{~mL})$. The mixture was stirred at room temperature for $16 \mathrm{~h}$. Solvent was removed under reduced pressure. The residue was dissolved in $\mathrm{H}_{2} \mathrm{O}$, acidified to $\mathrm{pH}=5$ with $6 \mathrm{~N} \mathrm{HCl}$, and neutralized with aqueous sat. $\mathrm{NaHCO}_{3}$. Precipitate was collected by filtration to give compound $\mathbf{1 8}$ as a pasty amorphous solid. Purity $99 \%$. $\mathrm{t}_{\mathrm{R}, \mathrm{LCMS}}=1.53 \mathrm{~min}$. MS 
(ESI-): $m / z=207[\mathrm{M}-\mathrm{H}]^{-} .{ }^{1} \mathrm{H}$ NMR $300 \mathrm{MHz}\left(\mathrm{CD}_{3} \mathrm{OD}-d_{4}\right) \delta(\mathrm{ppm}):$ 7.31-7.23 (m, 5H), $3.74(\mathrm{~s}$, 2H), 3.55 (s, 2H). ${ }^{13} \mathrm{C}$ NMR $75 \mathrm{MHz}\left(\mathrm{DMSO}-d_{6}\right) \delta(\mathrm{ppm}): 170.3,165.3,138.5,129.6,128.4$, 126.2, 44.4, 40.3. HRMS m/z calculated for $\mathrm{C}_{10} \mathrm{H}_{13} \mathrm{~N}_{2} \mathrm{O}_{3}[\mathrm{M}+\mathrm{H}]^{+}:$209.0926. Found: 209.0917.

N-[3-(Hydroxyamino)-3-oxo-propyl]benzamide (19). To a solution of methyl 3benzamidopropanoate $(0.123 \mathrm{~g}, 0.59 \mathrm{mmol}, 1$ equiv $)$ in $\mathrm{MeOH}(1.60 \mathrm{~mL}, 0.45 \mathrm{M})$ was added a solution of aqueous hydroxylamine $50 \%(1.30 \mathrm{~mL})$ and $\mathrm{KCN}(0.004 \mathrm{~g}, 0.05 \mathrm{mmol}, 0.1$ equiv). The mixture was stirred for $2 \mathrm{~h} 15 \mathrm{~min}$ at room temperature. It was then concentrated under vacuum and an aqueous workup was performed using $\mathrm{H}_{2} \mathrm{O} /$ EtOAc (1:50 (v:v)). The organic layer was evaporated under vacuum and purified by preparative HPLC using a linear acetonitrile/water (ammonium-acetate/formic acid buffer, $\mathrm{pH}=9.2$ ) gradient (2:98 to 100:0 over $25 \mathrm{~min})$, affording the hydroxamic acid 19 as a white powder $(0.077 \mathrm{~g}, 88 \%)$. Purity $99 \%$. mp: $156^{\circ} \mathrm{C} . \mathrm{t}_{\mathrm{R}, \mathrm{LCMS}}=1.48 \mathrm{~min} . \mathrm{MS}(\mathrm{ESI}-): m / z=207[\mathrm{M}-\mathrm{H}]^{-}, \mathrm{MS}(\mathrm{ESI}+): \mathrm{m} / z=209[\mathrm{M}+\mathrm{H}]^{+}$. ${ }^{1} \mathrm{H}$ NMR $300 \mathrm{MHz}\left(\mathrm{DMSO}-d_{6}\right) \delta(\mathrm{ppm}): 8.52(\mathrm{t}, J=5.5 \mathrm{~Hz}, 1 \mathrm{H}), 7.85-7.81(\mathrm{~m}, 2 \mathrm{H}), 7.54-7.41$ $(\mathrm{m}, 3 \mathrm{H}), 3.44(\mathrm{td}, J=7.1 \mathrm{~Hz}, J=5.5 \mathrm{~Hz}, 2 \mathrm{H}), 2.26(\mathrm{t}, J=7.1 \mathrm{~Hz}, 2 \mathrm{H}) .{ }^{13} \mathrm{C} \mathrm{NMR} 75 \mathrm{MHz}$ $\left(\mathrm{DMSO}-d_{6}\right) \delta(\mathrm{ppm}): 167.2,166.1,134.4,131.1,128.2,127.1,36.0,32.4$. HRMS $m / z$ calculated for $\mathrm{C}_{10} \mathrm{H}_{13} \mathrm{~N}_{2} \mathrm{O}_{3}[\mathrm{M}+\mathrm{H}]^{+}:$209.0926. Found: 209.0926.

N-Benzyl-3-(hydroxyamino)-3-oxo-propanamide (20). A solution of Meldrum's acid (0.445 g, $3.08 \mathrm{mmol}, 1$ equiv) and benzylamine $(0.800 \mathrm{~mL} ; 7.33 \mathrm{mmol}, 2.37$ equiv) in $\mathrm{MeCN}$ (2.50 mL, 1.2 M) was stirred at room temperature for $3 \mathrm{~h}$. A light yellow color appeared and white crystals quickly formed. They were filtered and washed with diethyl-ether affording the carboxylic acid 20b as white crystals $(0.374 \mathrm{~g}, 63 \%)$. $\mathrm{mp}: 176{ }^{\circ} \mathrm{C} . \mathrm{t}_{\mathrm{R}, \mathrm{LCMS}}=1.68 \mathrm{~min} . \mathrm{MS}(\mathrm{ESI}-): \mathrm{m} / \mathrm{z}=192$ [M-H] $]^{-}, \mathrm{MS}(\mathrm{ESI}+): \mathrm{m} / z=194[\mathrm{M}+\mathrm{H}]^{+}$. To a solution of $\mathbf{2 0 b}(0.340 \mathrm{~g}, 1.76 \mathrm{mmol}, 1$ equiv) in $\mathrm{MeOH}(5.90 \mathrm{~mL}, 0.3 \mathrm{M})$ at $0{ }^{\circ} \mathrm{C}$ was added dropwise thionyl chloride $(0.383 \mu \mathrm{L}, 5.28 \mathrm{mmol}$, 
3 equiv). The reaction mixture was stirred at room temperature for $30 \mathrm{~min}$, then solvents were evaporated in vacuo. White crystals were obtained. These crystals were dissolved in EtOAc and washed with aqueous $5 \% \mathrm{NaHCO}_{3}$. EtOAc was evaporated in vacuo and methyl ester $\mathbf{2 0 a}$ was crystallized from methanol affording colorless crystals $(0.168 \mathrm{~g}, 46 \%)$. mp: $108^{\circ} \mathrm{C} \cdot \mathrm{t}_{\mathrm{R}, \mathrm{LCMS}}=$ $1.98 \min$. MS (ESI-): $m / z=206[\mathrm{M}-\mathrm{H}]^{-}$, MS (ESI+): $m / z=208[\mathrm{M}+\mathrm{H}]^{+}$. To a solution of 20a $(0.159 \mathrm{~g}, 0.76 \mathrm{mmol}, 1$ equiv) in $\mathrm{MeOH}(1.60 \mathrm{~mL}, 0.45 \mathrm{M})$ was added a solution of aqueous hydroxylamine $50 \%(1.60 \mathrm{~mL})$ and $\mathrm{KCN}(0.005 \mathrm{~g}, 0.06 \mathrm{mmol}, 0.1$ equiv). The mixture was stirred $17 \mathrm{~h}$ at room temperature. It was concentrated under vacuum and an aqueous workup was performed using $\mathrm{H}_{2} \mathrm{O} /$ EtOAc (1:50 (v:v)). Solvents in the organic layer were evaporated under vacuum and purified by preparative HPLC using a linear acetonitrile/water gradient, containing ammonium-acetate/formic acid buffer $(\mathrm{pH}=9.2)$, starting with $\mathrm{H}_{2} \mathrm{O} 98 \%$ to reach acetonitrile $100 \%$ in $25 \mathrm{~min}$. Pure hydroxamic acid 20 was obtained as white crystals $(0.069 \mathrm{~g}$, 42\%). Purity $98 \% \cdot \mathrm{mp}: 135{ }^{\circ} \mathrm{C} \cdot \mathrm{t}_{\mathrm{R}, \mathrm{LCMS}}=1.55 \mathrm{~min} . \mathrm{MS}(\mathrm{ESI}-): \mathrm{m} / z=207[\mathrm{M}-\mathrm{H}]^{-}, \mathrm{MS}(\mathrm{ESI}+)$ : $m / z=209[\mathrm{M}+\mathrm{H}]^{+} .{ }^{1} \mathrm{H}$ NMR $300 \mathrm{MHz}\left(\mathrm{DMSO}-d_{6}\right) \delta(\mathrm{ppm}): 10.84(\mathrm{~s}, 1 \mathrm{H}), 8.91(\mathrm{~s}, 1 \mathrm{H}), 8.46$ $(\mathrm{t}, J=5.8 \mathrm{~Hz}, 1 \mathrm{H}), 7.34-7.20(\mathrm{~m}, 5 \mathrm{H}), 4.28(\mathrm{~d}, J=5.8 \mathrm{~Hz}, 2 \mathrm{H}), 2.96(\mathrm{~s}, 2 \mathrm{H}) .{ }^{13} \mathrm{C} \mathrm{NMR} 75 \mathrm{MHz}$ $\left(\mathrm{DMSO}-d_{6}\right) \delta(\mathrm{ppm}): 166.3,163.7,139.1,128.2,127.2,126.7,42.2,40.8$. HRMS $m / z$ calculated for $\mathrm{C}_{10} \mathrm{H}_{13} \mathrm{~N}_{2} \mathrm{O}_{3}[\mathrm{M}+\mathrm{H}]^{+}:$209.0926. Found: 209.0935.

$N$-Hydroxy- $N$ '-phenyl succinamide (21). Obtained following the general procedure B from 3(phenylcarbamoyl)propanoic acid. White powder (0.040 g, 12\%). Purity 99\%. mp: $122{ }^{\circ} \mathrm{C}$. $\mathrm{t}_{\mathrm{R}, \mathrm{LCMS}}=2.20 \mathrm{~min} . \mathrm{MS}(\mathrm{ESI}+): m / z=209[\mathrm{M}+\mathrm{H}]^{+} .{ }^{1} \mathrm{H}$ NMR $300 \mathrm{MHz}$ (acetone- $\left.d_{6}\right) \delta(\mathrm{ppm})$ : $7.63(\mathrm{~d}, J=6.9 \mathrm{~Hz}, 2 \mathrm{H}), 7.26(\mathrm{t}, J=6.9 \mathrm{~Hz}, 2 \mathrm{H}), 7.02(\mathrm{t}, J=6.9 \mathrm{~Hz}, 1 \mathrm{H}), 2.65(\mathrm{br} \mathrm{s}, 2 \mathrm{H}), 2.46$ (br s, 2H). ${ }^{13} \mathrm{C}$ NMR $75 \mathrm{MHz}$ (acetone- $\left.d_{6}\right) \delta$ (ppm): 170.0, 169.4, 139.4, 128.6, 123.1, 119.0, 31.8, 27.5. HRMS $m / z$ calculated for $\mathrm{C}_{10} \mathrm{H}_{13} \mathrm{~N}_{2} \mathrm{O}_{3}[\mathrm{M}+\mathrm{H}]^{+}:$209.0926. Found: 209.0923. 
N-hydroxy-2-methyl-4-phenyl-butyramide (22). Obtained following the general procedure B from 22b. White powder $(0.160 \mathrm{~g}, 25 \%)$. Purity $99 \% . \mathrm{mp}: 134{ }^{\circ} \mathrm{C} . \mathrm{t}_{\mathrm{R}, \mathrm{LCMS}}=2.57 \mathrm{~min} . \mathrm{MS}$ (ESI+): $m / z=194[\mathrm{M}+\mathrm{H}]^{+} .{ }^{1} \mathrm{H}$ NMR $300 \mathrm{MHz}\left(\mathrm{DMSO}-d_{6}\right) \delta(\mathrm{ppm}): 10.42(\mathrm{br} \mathrm{s}, 1 \mathrm{H}), 8.72(\mathrm{br}$ $\mathrm{s}, 1 \mathrm{H}), 7.29-7.14(\mathrm{~m}, 5 \mathrm{H}), 2.49-2.45(\mathrm{~m}, 2 \mathrm{H}), 2.13-2.10(\mathrm{~m}, 1 \mathrm{H}), 1.80-1.74(\mathrm{~m}, 1 \mathrm{H}), 1.56-1.54$ $(\mathrm{m}, 1 \mathrm{H}), 1.02(\mathrm{~d}, J=6.6 \mathrm{~Hz}, 3 \mathrm{H}) .{ }^{13} \mathrm{C}$ NMR $75 \mathrm{MHz}\left(\mathrm{DMSO}-d_{6}\right) \delta(\mathrm{ppm}): 172.7,142.3,128.8$, 128.6, 126.2, 36.9, 35.8, 33.5, 18.4. HRMS $m / z$ calculated for $\mathrm{C}_{11} \mathrm{H}_{16} \mathrm{NO}_{2}[\mathrm{M}+\mathrm{H}]^{+}:$: 194.1181 . Found: 194.1182.

2-Benzyl-4-phenyl-butanehydroxamic acid (23). Obtained following the general procedure $\mathbf{B}$ from 23b. White amorphous solid $(0.037 \mathrm{~g}, 13 \%)$. Purity: $95 \% . \mathrm{mp}: 131^{\circ} \mathrm{C} . \mathrm{t}_{\mathrm{R}, \mathrm{LCMS}}=2.58 \mathrm{~min}$. MS (ESI+): $m / z=270[\mathrm{M}+\mathrm{H}]^{+} .{ }^{1} \mathrm{H}$ NMR $300 \mathrm{MHz}\left(\mathrm{DMSO}-d_{6}\right) \delta(\mathrm{ppm}): 10.45(\mathrm{br} \mathrm{s}, 1 \mathrm{H}), 8.78$ (br s, 1H), 7.28-7.11 (m, 10H), $2.84(\mathrm{dd}, J=8.4 \mathrm{~Hz}, J=13.5 \mathrm{~Hz}, 1 \mathrm{H}), 2.63(\mathrm{dd}, J=6.9 \mathrm{~Hz}, J$ $=13.5 \mathrm{~Hz}, 1 \mathrm{H}), 2.50-2.31(\mathrm{~m}, 3 \mathrm{H}), 1.83-1.73(\mathrm{~m}, 1 \mathrm{H}), 1.64-1.53(\mathrm{~m}, 1 \mathrm{H}) .{ }^{13} \mathrm{C} \mathrm{NMR} 75 \mathrm{MHz}$ $\left(\mathrm{DMSO}-d_{6}\right) \delta(\mathrm{ppm}): 171.1,142.2,140.2,129.3,128.8,128.6,128.5,126.5,126.2,44.8,38.6$ 34.4, 33.5. HRMS $m / z$ calculated for $\mathrm{C}_{17} \mathrm{H}_{20} \mathrm{NO}_{2}[\mathrm{M}+\mathrm{H}]^{+}:$: 270.1494. Found: 270.1503 .

2-Benzenesulfonyl-N-hydroxy-4-phenyl-butyramide (24). Obtained following the general procedure B from 24b. White powder $(0.07 \mathrm{~g}, 63 \%)$. Purity $99 \% . \mathrm{mp}: 176{ }^{\circ} \mathrm{C} \cdot \mathrm{t}_{\mathrm{R}, \mathrm{LCMS}}=2.70$ min. MS (ESI+): $m / z=320[\mathrm{M}+\mathrm{H}]^{+} .{ }^{1} \mathrm{H}$ NMR $300 \mathrm{MHz}$ (DMSO-d $) \delta(\mathrm{ppm}): 10.94$ (br s, $\left.1 \mathrm{H}\right)$, 9.32 (br s, $1 \mathrm{H})$, 7.79-7.73 (m, 3H), 7.65-7.60 (m, 2H), 7.25-7.18 (m, 3H), 7.09-7.06 (m, 2H), $3.76(\mathrm{~s}, 1 \mathrm{H}), 2.50-2.37$ (m, 2H), 1.99 (br s, 2H). ${ }^{13} \mathrm{C}$ NMR $75 \mathrm{MHz}$ (DMSO- $\left.d_{6}\right) \delta(\mathrm{ppm}): 160.7$, 140.4, 137.4, 134.7, 129.6, 128.9, 128.6, 126.7, 67.1, 32.2, 28.7. HRMS m/z calculated for $\mathrm{C}_{16} \mathrm{H}_{18} \mathrm{NO}_{4} \mathrm{~S}[\mathrm{M}+\mathrm{H}]^{+}:$320.0957. Found: 320.0956 .

2-Benzenesulfonyl-N-hydroxy-2-methyl-4-phenyl-butyramide (25). Obtained following the general procedure B from 25a. White powder $(0.020 \mathrm{~g}, 12 \%)$. Purity $99 \%$. mp: $159{ }^{\circ} \mathrm{C} . \mathrm{t}_{\mathrm{R}, \mathrm{LCMS}}$ $=2.82 \mathrm{~min} . \mathrm{MS}(\mathrm{ESI}+): m / z=334[\mathrm{M}+\mathrm{H}]^{+} .{ }^{1} \mathrm{H}$ NMR $300 \mathrm{MHz}\left(\mathrm{CDCl}_{3}\right) \delta(\mathrm{ppm}): 7.82(\mathrm{~d}, J=$ 7.5 Hz, 2H), 7.73-7.68 (m, 1H), 7.60-7.55 (m, 2H), 7.32-7.14 (m, 5H), 2.69-2.55 (m, 3H), 2.24- 
$2.14(\mathrm{~m}, 1 \mathrm{H}), 1.58(\mathrm{~s}, 3 \mathrm{H}) .{ }^{13} \mathrm{C} \mathrm{NMR} 75 \mathrm{MHz}\left(\mathrm{CDCl}_{3}\right) \delta(\mathrm{ppm}): 165.1,140.0,134.7,134.5$, 130.1, 129.3, 128.6, 128.3, 126.5, 71.0, 35.1, 30.3, 16.7. HRMS $m / z$ calculated for $\mathrm{C}_{17} \mathrm{H}_{20} \mathrm{NO}_{4} \mathrm{~S}$ $[\mathrm{M}+\mathrm{H}]^{+}:$334.1113. Found: 334.1113 .

2-Benzyl-N-hydroxy-2-methanesulfonyl-4-phenyl-butyramide (26). Obtained following the general procedure B from 26a. White solid $(0.047 \mathrm{~g}, 10 \%)$. Purity $99 \%$. mp: $105^{\circ} \mathrm{C} . \mathrm{t}_{\mathrm{R}, \mathrm{LCMS}}=$ $2.90 \mathrm{~min}$. MS (ESI+): $m / z=348[\mathrm{M}+\mathrm{H}]^{+} .{ }^{1} \mathrm{H}$ NMR $300 \mathrm{MHz}\left(\mathrm{CD}_{3} \mathrm{OD}-d_{4}\right) \delta(\mathrm{ppm}): 7.40-7.32$ $(\mathrm{m}, 5 \mathrm{H}), 7.30-7.13(\mathrm{~m}, 3 \mathrm{H}), 7.10(\mathrm{~d}, J=6.9 \mathrm{~Hz}, 2 \mathrm{H}), 3.85(\mathrm{~d}, J=13.8 \mathrm{~Hz}, 1 \mathrm{H}), 3.40(\mathrm{~d}, J=$ $13.8 \mathrm{~Hz}, 1 \mathrm{H}), 3.06(\mathrm{~s}, 3 \mathrm{H}), 2.85-2.80(\mathrm{~m}, 2 \mathrm{H}), 2.36-2.26(\mathrm{~m}, 1 \mathrm{H}), 2.11-2.00(\mathrm{~m}, 1 \mathrm{H}) .{ }^{13} \mathrm{C} \mathrm{NMR}$ $75 \mathrm{MHz}\left(\mathrm{CD}_{3} \mathrm{OD}-d_{4}\right) \delta(\mathrm{ppm}): 165.4,141.4,134.7,130.2,128.7,128.2,127.9,127.1,125.7$, 73.9, 38.2, 36.6, 35.7, 29.9. HRMS $m / z$ calculated for $\mathrm{C}_{18} \mathrm{H}_{22} \mathrm{NO}_{4} \mathrm{~S}[\mathrm{M}+\mathrm{H}]^{+}:$348.1270. Found: 348.1288 .

(S)-2-Benzylamino- $N$-hydroxy-propionamide (27). Obtained following the general procedure $\mathbf{B}$ from 27b. White powder $(0.030 \mathrm{~g}, 8 \%)$. Purity $87 \% . \mathrm{mp}: 154^{\circ} \mathrm{C} . \mathrm{t}_{\mathrm{R}, \mathrm{LCMS}}=1.22 \mathrm{~min} . \mathrm{MS}(\mathrm{ESI}+)$ : $m / z=195[\mathrm{M}+\mathrm{H}]^{+} .{ }^{1} \mathrm{H}$ NMR $300 \mathrm{MHz}\left(\mathrm{DMSO}-d_{6}\right) \delta(\mathrm{ppm}): 8.81(\mathrm{br} \mathrm{s}, 1 \mathrm{H}), 7.31-7.20(\mathrm{~m}, 5 \mathrm{H})$, $3.66(\mathrm{~d}, J=13.2 \mathrm{~Hz}, 1 \mathrm{H}), 3.49(\mathrm{~d}, J=13.2 \mathrm{~Hz}, 1 \mathrm{H}), 2.99(\mathrm{q}, J=6.9 \mathrm{~Hz}, 1 \mathrm{H}), 1.11(\mathrm{~d}, J=6.9$ $\mathrm{Hz}, 3 \mathrm{H}) .{ }^{13} \mathrm{C}$ NMR $75 \mathrm{MHz}$ (DMSO- $\left.d_{6}\right) \delta$ (ppm): 171.7, 140.9, 128.6, 128.3, 127.1, 54.4, 51.1, 19.9. HRMS $m / z$ calculated for $\mathrm{C}_{10} \mathrm{H}_{15} \mathrm{~N}_{2} \mathrm{O}_{4}[\mathrm{M}+\mathrm{H}]^{+}$: 195.1134. Found: 195.1124 .

(S)-2-Benzylamino-N-hydroxy-3-phenyl-propionamide (28). Obtained following the general procedure B from 28b. White solid (0.095 g, 13\%). Purity: 99\%. mp: $163{ }^{\circ} \mathrm{C} . \mathrm{t}_{\mathrm{R}, \mathrm{LCMS}}=2.25$ min. MS (ESI+): $m / z=271[\mathrm{M}+\mathrm{H}]^{+} .{ }^{1} \mathrm{H}$ NMR $300 \mathrm{MHz}\left(\mathrm{DMSO}-d_{6}\right) \delta(\mathrm{ppm}): 11.00(\mathrm{br} \mathrm{s}, 1 \mathrm{H})$, 9.56 (br s, 1H), 9.34 (br s, 1H), 7.46-7.42 (m, 5H), 7.32-7.27 (m, 3H), $7.17(\mathrm{~d}, J=6.9 \mathrm{~Hz}, 2 \mathrm{H})$, $4.03(\mathrm{~s}, 2 \mathrm{H}), 3.77-3.72(\mathrm{~m}, 2 \mathrm{H}), 3.20-3.00(\mathrm{~m}, 2 \mathrm{H}) .{ }^{13} \mathrm{C}$ NMR $75 \mathrm{MHz}$ (DMSO-d $) \delta(\mathrm{ppm})$ : $163.3,135.2,132.0,130.5,129.8,129.5,129.2,129.0,127.7,59.0,49.4,36.0$. HRMS $m / z$ calculated for $\mathrm{C}_{16} \mathrm{H}_{19} \mathrm{~N}_{2} \mathrm{O}_{2}[\mathrm{M}+\mathrm{H}]^{+}:$271.1447. Found: 271.1438 . 
Obtained following the general procedure B from 29b. White solid $(0.046 \mathrm{~g}, 8 \%)$. Purity $90 \%$. mp: $179{ }^{\circ} \mathrm{C} . \mathrm{t}_{\mathrm{R}, \mathrm{LCMS}}=2.53 \mathrm{~min} . \mathrm{MS}(\mathrm{ESI}+): \mathrm{m} / z=301[\mathrm{M}+\mathrm{H}]^{+} .{ }^{1} \mathrm{H}$ NMR $300 \mathrm{MHz}\left(\mathrm{CD}_{3} \mathrm{OD}-\right.$ $\left.d_{4}\right) \delta(\mathrm{ppm}): 7.97(\mathrm{~d}, J=8.1 \mathrm{~Hz}, 2 \mathrm{H}), 7.73(\mathrm{~d}, J=8.1 \mathrm{~Hz}, 2 \mathrm{H}), 7.67(\mathrm{~d}, J=7.5 \mathrm{~Hz}, 2 \mathrm{H}) 7.46(\mathrm{t}$, $J=7.5 \mathrm{~Hz}, 2 \mathrm{H}), 7.38(\mathrm{~d}, J=7.5 \mathrm{~Hz}, 1 \mathrm{H}), 4.63(\mathrm{t}, J=5.7 \mathrm{~Hz}, 2 \mathrm{H}), 3.89(\mathrm{~d}, J=5.7 \mathrm{~Hz}, 1 \mathrm{H}) .{ }^{13} \mathrm{C}$ NMR $75 \mathrm{MHz}\left(\mathrm{CD}_{3} \mathrm{OD}-d_{4}\right) \delta(\mathrm{ppm}): 168.4,168.2,144.6,139.8,132.3,128.6,127.8,126.7$, 126.6, 61.5, 53.9. HRMS $m / z$ calculated for $\mathrm{C}_{16} \mathrm{H}_{17} \mathrm{~N}_{2} \mathrm{O}_{4} \mathrm{~S}[\mathrm{M}+\mathrm{H}]^{+}: 301.1188$. Found: 301.1198 . N-Benzyl-3-(hydroxyamino)-2-methyl-3-oxo-propanamide (30). Obtained following the general procedure $\mathbf{C}$ from commercial 1,3-diethyl 2-methylpropanedioate. White powder (0.025 g, 4\%). Purity 99\%. mp: $138{ }^{\circ} \mathrm{C} . \mathrm{t}_{\mathrm{R}, \mathrm{LCMS}}=1.65 \mathrm{~min} . \mathrm{MS}(\mathrm{ESI}-): \mathrm{m} / z=221[\mathrm{M}-\mathrm{H}]^{-}, \mathrm{MS}$ (ESI+): $m / z=223[\mathrm{M}+\mathrm{H}]^{+} .{ }^{1} \mathrm{H}$ NMR $300 \mathrm{MHz}\left(\mathrm{DMSO}-d_{6}\right) \delta(\mathrm{ppm}): 10.38(\mathrm{br} \mathrm{s}, 1 \mathrm{H}), 8.90(\mathrm{~s}$, $1 \mathrm{H}), 8.17(\mathrm{t}, J=5.7 \mathrm{~Hz}, 1 \mathrm{H}), 7.33-7.22(\mathrm{~m}, 5 \mathrm{H}), 4.26(\mathrm{~d}, J=5.7 \mathrm{~Hz}, 2 \mathrm{H}), 3.07(\mathrm{q}, J=7.1 \mathrm{~Hz}$, 1H), $1.22(\mathrm{~d}, J=7.1 \mathrm{~Hz}, 3 \mathrm{H}) .{ }^{13} \mathrm{C}$ NMR $75 \mathrm{MHz}\left(\mathrm{DMSO}-d_{6}\right) \delta(\mathrm{ppm}): 169.6,167.4,139.3$, 128.2, 127.1, 126.7, 44.3, 42.2, 14.6. HRMS $m / z$ calculated for $\mathrm{C}_{11} \mathrm{H}_{15} \mathrm{~N}_{2} \mathrm{O}_{3}[\mathrm{M}+\mathrm{H}]^{+}: 223.1083$. Found: 223.1086.

N,2-Dibenzyl-3-(hydroxyamino)-3-oxo-propanamide (31). Obtained following the general procedure C from commercial 1,3-diethyl 2-benzylpropanedioate. White crystals $(0.201 \mathrm{~g}$, 27\%). Purity 99\%. TLC dichloromethane/methanol 95:05 (v:v) $R_{f}=0.55 . \mathrm{mp}: 179{ }^{\circ} \mathrm{C} . \mathrm{t}_{\mathrm{R}, \mathrm{LCMS}}$ $=2.22 \min . \mathrm{MS}(\mathrm{ESI}-): m / z=297[\mathrm{M}-\mathrm{H}]^{-}, \mathrm{MS}(\mathrm{ESI}+): m / z=299[\mathrm{M}+\mathrm{H}]^{+} .{ }^{1} \mathrm{H} \mathrm{NMR} 300 \mathrm{MHz}$ $\left(\mathrm{DMSO}-d_{6}\right) \delta(\mathrm{ppm}): 10.43(\mathrm{~s}, 1 \mathrm{H}), 8.92(\mathrm{~s}, 1 \mathrm{H}), 8.19(\mathrm{t}, J=5.7 \mathrm{~Hz}, 1 \mathrm{H}), 7.28-7.09(\mathrm{~m}, 10 \mathrm{H})$, $4.29(\mathrm{dd}, J=6.1 \mathrm{~Hz}, J=15.2 \mathrm{~Hz}, 1 \mathrm{H}), 4.18(\mathrm{dd}, J=5.5 \mathrm{~Hz}, J=15.2 \mathrm{~Hz}, 1 \mathrm{H}), 3.30(\mathrm{t}, J=7.5$ $\mathrm{Hz}, 1 \mathrm{H}), 3.04(\mathrm{t}, J=5.7 \mathrm{~Hz}, 2 \mathrm{H}) .{ }^{13} \mathrm{C} \mathrm{NMR} 75 \mathrm{MHz}\left(\mathrm{DMSO}-d_{6}\right) \delta(\mathrm{ppm}): 168.1,165.7,139.1$, 138.9, 128.8, 128.1, 127.0, 126.6, 126.1, 52.3, 42.2, 34.6. HRMS $m / z$ calculated for $\mathrm{C}_{17} \mathrm{H}_{19} \mathrm{~N}_{2} \mathrm{O}_{3}$ $[\mathrm{M}+\mathrm{H}]^{+}:$299.1396. Found: 299.1399 . 
N-Benzyl-3-(hydroxyamino)-3-oxo-2-(4-pyridylmethyl)propanamide (32). To a solution of commercial dimethyl malonate $\left(1.068 \mathrm{~g}, 8.08 \mathrm{mmol}, 1\right.$ equiv) in THF $(15 \mathrm{~mL}, 0.5 \mathrm{M})$ at $0{ }^{\circ} \mathrm{C}$ was carefully added $\mathrm{NaH} 60 \%$ dispersion in mineral oil ( $0.679 \mathrm{~g}, 17 \mathrm{mmol}, 2.1$ equiv) the mixture was allowed to come back to room temperature and stirred for $30 \mathrm{~min}$ before 4(chloromethyl)pyridine hydrochloride $(1.193 \mathrm{~g}, 7.27 \mathrm{mmol}, 0.9$ equiv) was added and the mixture was stirred at $40{ }^{\circ} \mathrm{C}$ for $5 \mathrm{~h}$. Solvents were evaporated in vacuo and the residue was purified by flash silica gel column chromatography (cyclohexane/EtOAc, 100:0 to 50:50) affording 61 as a colorless oil. $\mathrm{t}_{\mathrm{R}, \mathrm{LCMS}}=1.62 \mathrm{~min}$. MS $(\mathrm{ESI}+): \mathrm{m} / z=224[\mathrm{M}+\mathrm{H}]^{+}$. Degradation occurs very quickly, the oil turning rapidly reddish, then blackish and solids then start to form. A degradation rate of $55 \%$ was calculated based on UV-LCMS. This intermediate $(0.870 \mathrm{~g}$, $23 \%$ ) was engaged in the next step, following general procedure $\mathbf{C}$ without further purification. 32 was thus obtained as a white solid $(0.02 \mathrm{~g}, 7 \%)$. Purity $99 \% . \mathrm{mp}: 87^{\circ} \mathrm{C} . \mathrm{t}_{\mathrm{R}, \mathrm{LCMS}}=1.52 \mathrm{~min}$. MS (ESI-): $m / z=298[\mathrm{M}-\mathrm{H}]^{-}, \mathrm{MS}(\mathrm{ESI}+): m / z=300[\mathrm{M}+\mathrm{H}]^{+} .{ }^{1} \mathrm{H}$ NMR $300 \mathrm{MHz}\left(\mathrm{DMSO}-d_{6}\right)$ $\delta(\mathrm{ppm}): 10.46(\mathrm{~s}, 1 \mathrm{H}), 8.97(\mathrm{~s}, 1 \mathrm{H}), 8.44(\mathrm{~d}, J=1.4 \mathrm{~Hz}, 2 \mathrm{H}), 8.26(\mathrm{t}, J=5.8 \mathrm{~Hz}, 1 \mathrm{H}), 7.30-$ $7.11(\mathrm{~m}, 7 \mathrm{H}), 4.29(\mathrm{dd}, J=15.1 \mathrm{~Hz}, J=6.0 \mathrm{~Hz}, 1 \mathrm{H}), 4.19(\mathrm{dd}, J=15.1 \mathrm{~Hz}, J=5.7 \mathrm{~Hz}, 1 \mathrm{H})$, $3.35(\mathrm{t}, J=7.6 \mathrm{~Hz}, 1 \mathrm{H}), 3.06(\mathrm{dd}, J=7.6 \mathrm{~Hz}, J=2.6 \mathrm{~Hz}, 1 \mathrm{H}), 3.08(\mathrm{dd}, J=7.6 \mathrm{~Hz}, J=3.5 \mathrm{~Hz}$, 1H). ${ }^{13} \mathrm{C}$ NMR $75 \mathrm{MHz}\left(\mathrm{DMSO}-d_{6}\right) \delta$ (ppm): 167.7, 165.3, 149.3, 147.8, 139.0, 128.2, 127.0, 126.7, 124.2, 51.0, 42.2, 33.6. HRMS $\mathrm{m} / z$ calculated for $\mathrm{C}_{16} \mathrm{H}_{18} \mathrm{~N}_{3} \mathrm{O}_{3}[\mathrm{M}+\mathrm{H}]^{+}: 300.1348$. Found: 300.1376.

N-Benzyl-3-(hydroxyamino)-2-(2-naphthylmethyl)-3-oxo-propanamide (33). Meldrum's acid (0.500 g, $3.47 \mathrm{mmol}, 1$ equiv) and 2-naphthaldehyde (0.542 g, $3.47 \mathrm{mmol}, 1$ equiv) were dissolved in acetonitrile ( $4 \mathrm{~mL}, 1 \mathrm{M}$ ) and stirred at room temperature for $1 \mathrm{~h} 30 \mathrm{~min}$. A solution of Hantzsch's ester ( $0.879 \mathrm{~g}, 3.47 \mathrm{mmol}, 1$ equiv) in methanol ( $3 \mathrm{~mL})$ was added to the mixture, followed by L-proline $(0.080 \mathrm{~g}, 0.69 \mathrm{mmol}, 0.2$ equiv). The resulting mixture was stirred overnight at room temperature. A precipitate was formed and dissolved when the mixture was 
diluted with acetonitrile. Solvents were evaporated in vacuo and the residue was triturated in methanol, affording 2,2-dimethyl-5-(2-naphthylmethyl)-1,3-dioxane-4,6-dione $\mathbf{6 0}$ as a white solid $(0.676 \mathrm{~g}, 68 \%)$. Purity 99\%. $\mathrm{t}_{\mathrm{R}, \mathrm{LCMS}}=1.17 \mathrm{~min} . \mathrm{MS}(\mathrm{ESI}+): \mathrm{m} / \mathrm{z}=285[\mathrm{M}+\mathrm{H}]^{+} .{ }^{1} \mathrm{H} \mathrm{NMR}$ $300 \mathrm{MHz}\left(\mathrm{CDCl}_{3}\right) \delta(\mathrm{ppm}): 7.82-7.76(\mathrm{~m}, 4 \mathrm{H}), 7.50-7.42(\mathrm{~m}, 3 \mathrm{H}), 3.84(\mathrm{t}, J=4.9 \mathrm{~Hz}, 1 \mathrm{H}), 3.65$ $(\mathrm{d}, J=4.9 \mathrm{~Hz}, 2 \mathrm{H}), 1.73(\mathrm{~s}, 3 \mathrm{H}), 1.50(\mathrm{~s}, 3 \mathrm{H}) .{ }^{13} \mathrm{C} \mathrm{NMR} 75 \mathrm{MHz}\left(\mathrm{CDCl}_{3}\right) \delta(\mathrm{ppm}): 165.4$, $134.9,133.5,132.6,128.7,128.4,128.0,127.9,127.7,126.3,126.0,105.3,48.4,32.3,28.6$, 27.3. A solution of $\mathbf{6 0}(0.097 \mathrm{~g}, 0.34 \mathrm{mmol}, 1$ equiv) and benzylamine $(0.037 \mathrm{~mL}, 0.34 \mathrm{mmol}$, 1 equiv) in acetonitrile $(0.480 \mathrm{~mL}, 0.7 \mathrm{M})$ was heated under microwaves irradiation at $80{ }^{\circ} \mathrm{C}$ for $1 \mathrm{~h} 45 \mathrm{~min}$. The product spontaneously crystallized from the light yellow reaction mixture at room temperature. It was filtered off and washed with diethyl ether, affording 3(benzylamino)-2-(2-naphthylmethyl)-3-oxo-propanoic acid 33b (0.112 g, 95\%) as light-yellow crystals. $\mathrm{t}_{\mathrm{R}, \mathrm{LCMS}}=2.62 \mathrm{~min}$. MS (ESI-): $m / z=332[\mathrm{M}-\mathrm{H}]^{-}$, MS (ESI+): $\mathrm{m} / z=334[\mathrm{M}+\mathrm{H}]^{+}$. To a solution of carboxylic acid $\mathbf{3 3 b}(0.112 \mathrm{~g}, 0.33 \mathrm{mmol}, 1$ equiv $)$ in methanol $(1 \mathrm{~mL}, 0.3 \mathrm{M})$ at $0{ }^{\circ} \mathrm{C}$ was added dropwise thionyl chloride $(0.073 \mathrm{~mL}, 1.00 \mathrm{mmol}, 3$ equiv). The reaction mixture was stirred at room temperature for $5 \mathrm{~h}$ before methanol was evaporated in vacuo. A white powder was obtained and dissolved in ethyl acetate, washed with sat. aqueous $\mathrm{NaHCO}_{3}$ twice. Organic fractions were pooled and evaporated under vacuum, affording methyl 3(benzylamino)-2-(2-naphthylmethyl)-3-oxo-propanoate 33a as a white powder $(0.105 \mathrm{~g}, 89 \%)$. $\mathrm{t}_{\mathrm{R}, \mathrm{LCMS}}=2.98 \mathrm{~min} . \mathrm{MS}(\mathrm{ESI}-): \mathrm{m} / z=346[\mathrm{M}-\mathrm{H}]^{-}, \mathrm{MS}(\mathrm{ESI}+): \mathrm{m} / z=348[\mathrm{M}+\mathrm{H}]^{+}$. To a solution of 33a $(0.105 \mathrm{~g}, 0.30 \mathrm{mmol}, 1$ equiv) in $\mathrm{MeOH}(0.660 \mathrm{~mL}, 0.45 \mathrm{M})$ was added a solution of aqueous hydroxylamine $50 \%(0.660 \mathrm{~mL})$ and $\mathrm{KCN}(0.02 \mathrm{~g}, 0.028 \mathrm{mmol}, 0.1$ equiv). The mixture was stirred for $4 \mathrm{~h}$ at room temperature. It was concentrated under vacuum and an aqueous workup was performed using $\mathrm{H}_{2} \mathrm{O} /$ EtOAc (1:50 (v:v)). Solvents in the organic layer were evaporated under vacuum and the residue was purified by preparative HPLC using a linear acetonitrile/water gradient, containing ammonium-acetate/formic acid buffer $(\mathrm{pH}=9.2)$, 
starting with $\mathrm{H}_{2} \mathrm{O} 98 \%$ to reach acetonitrile $100 \%$ in $25 \mathrm{~min}$. Pure hydroxamic acid $\mathbf{3 3}$ was obtained as a white powder $(0.039 \mathrm{~g}, 36 \%)$. Purity $99 \%$. $\mathrm{t}_{\mathrm{R}, \mathrm{LCMS}}=2.52 \mathrm{~min}$. MS (ESI-): $\mathrm{m} / \mathrm{z}=$ $347[\mathrm{M}-\mathrm{H}]^{-}, \mathrm{MS}(\mathrm{ESI}+): m / z=349[\mathrm{M}+\mathrm{H}]^{+} .{ }^{1} \mathrm{H}$ NMR $300 \mathrm{MHz}\left(\mathrm{DMSO}-d_{6}\right) \delta(\mathrm{ppm}): 10.43(\mathrm{~s}$, $1 \mathrm{H}), 8.93(\mathrm{~s}, 1 \mathrm{H}), 8.25(\mathrm{t}, J=5.9 \mathrm{~Hz}, 1 \mathrm{H}), 7.88-7.78(\mathrm{~m}, 3 \mathrm{H}), 7.69(\mathrm{~s}, 1 \mathrm{H}), 7.51-7.36(\mathrm{~m}, 3 \mathrm{H})$, 7.15-7.01 (m, 5H), $4.31(\mathrm{dd}, J=6.2 \mathrm{~Hz}, J=15.3 \mathrm{~Hz}, 1 \mathrm{H}), 4.17(\mathrm{dd}, J=5.4 \mathrm{~Hz}, J=15.3 \mathrm{~Hz}$, $1 \mathrm{H}), 3.43(\mathrm{t}, J=7.5 \mathrm{~Hz}, 1 \mathrm{H}), 3.22(\mathrm{t}, J=7.5 \mathrm{~Hz}, 2 \mathrm{H}) .{ }^{13} \mathrm{C}$ NMR $75 \mathrm{MHz}$ (DMSO- $\left.d_{6}\right) \delta(\mathrm{ppm})$ : $168.1,165.7,139.0,136.6,133.0,131.8,128.0,127.7,127.6,127.5,127.4,127.0,126.9,125.9$, 125.4, 52.3, 42.2, 34.9. HRMS $m / z$ calculated for $\mathrm{C}_{21} \mathrm{H}_{21} \mathrm{~N}_{2} \mathrm{O}_{3}[\mathrm{M}+\mathrm{H}]^{+}$: 349.1552. Found: 349.1545 .

N,2-Dibenzyl-3-(hydroxyamino)-2-methyl-3-oxo-propanamide (34). To a solution of alcoholate ethoxysodium ( $3.8 \mathrm{~mL}, 13.33 \mathrm{mmol}, 1.2$ equiv) cooled to $0{ }^{\circ} \mathrm{C}$ with an ice bath was added commercial diethyl 2-methylpropanedioate $(1 \mathrm{~mL}, 8.61 \mathrm{mmol}, 1$ equiv). Then the mixture was heated to $50{ }^{\circ} \mathrm{C}$ for $1 \mathrm{~h}$ and bromomethylbenzene $(0.927 \mathrm{~mL}, 7.75 \mathrm{mmol}, 0.9$ equiv $)$ was added. The mixture was heated again to $50{ }^{\circ} \mathrm{C}$ during $19 \mathrm{~h}$ and solvent was evaporated under vacuum. The crude product was dissolved in EtOAc and aqueous sat. $\mathrm{NaHCO}_{3}$ then the organic layer was washed three time with aqueous sat. $\mathrm{NaHCO}_{3}$ and one time with aqueous $\mathrm{NaOH} 10 \%$ then dried with $\mathrm{MgSO}_{4}$ and evaporated under vacuum to give not pure diethyl 2-benzyl-2-methylpropanedioate $62(1.409 \mathrm{~g}, 37 \%)$ as an orange oil. Purity $60 \%$. $\mathrm{t}_{\mathrm{R}, \mathrm{LCMS}}=3.28 \mathrm{~min}$. MS (ESI+): $m / z=265[\mathrm{M}+\mathrm{H}]^{+}$. This synthesis intermediate was used for general procedure $\mathbf{C}$ without further purification. 34 was obtained as a white solid (0.089 g, 12\%). Purity 99\%. mp: $66{ }^{\circ} \mathrm{C}$. $\mathrm{t}_{\mathrm{R}, \mathrm{LCMS}}=2.33 \mathrm{~min} . \mathrm{MS}(\mathrm{ESI}-): \mathrm{m} / z=311[\mathrm{M}-\mathrm{H}]^{-}, \mathrm{MS}(\mathrm{ESI}+): \mathrm{m} / z=313[\mathrm{M}+\mathrm{H}]^{+} .{ }^{1} \mathrm{H} \mathrm{NMR}$ $300 \mathrm{MHz}\left(\mathrm{DMSO}-d_{6}\right) \delta(\mathrm{ppm}): 8.23(\mathrm{t}, J=5.5 \mathrm{~Hz}, 1 \mathrm{H}), 7.32-7.08(\mathrm{~m}, 10 \mathrm{H}), 4.28(\mathrm{t}, J=5.5 \mathrm{~Hz}$, 2H), $3.17(\mathrm{~d}, J=13.2 \mathrm{~Hz}, 1 \mathrm{H}), 3.08(\mathrm{~d}, J=13.2 \mathrm{~Hz}, 1 \mathrm{H}), 1.16(\mathrm{~s}, 1 \mathrm{H}) .{ }^{13} \mathrm{C} \mathrm{NMR} 75 \mathrm{MHz}$ $\left(\mathrm{DMSO}-d_{6}\right) \delta(\mathrm{ppm}): 171.4,169.1,139.4,137.1,130.1,128.1,127.8,127.1,126.6,126.3,52.9$, 42.5, 41.7, 18.8. HRMS $m / z$ calculated for $\mathrm{C}_{18} \mathrm{H}_{21} \mathrm{~N}_{2} \mathrm{O}_{3}[\mathrm{M}+\mathrm{H}]^{+}:$313.1552. Found: 313.1560. 
N-Benzyl-3-(hydroxyamino)-2,2-dimethyl-3-oxo-propanamide (35). Obtained following the general procedure $\mathbf{C}$ from commercial 1,3-diethyl 2,2-dimethylpropanedioate. White solid (0.02 g, 7\%). Purity 99\%. mp: $133{ }^{\circ} \mathrm{C} \cdot \mathrm{t}_{\mathrm{R}, \mathrm{LCMS}}=1.73 \mathrm{~min} . \mathrm{MS}(\mathrm{ESI}-): \mathrm{m} / z=235[\mathrm{M}-\mathrm{H}]^{-}, \mathrm{MS}$ $(\mathrm{ESI}+): m / z=237[\mathrm{M}+\mathrm{H}]^{+} .{ }^{1} \mathrm{H}$ NMR $300 \mathrm{MHz}\left(\mathrm{DMSO}-d_{6}\right) \delta(\mathrm{ppm}): 8.33(\mathrm{~s}, 1 \mathrm{H}), 8.07(\mathrm{t}, J=$ $5.8 \mathrm{~Hz}, 1 \mathrm{H}), 7.36-7.18(\mathrm{~m}, 5 \mathrm{H}), 4.26(\mathrm{~d}, J=5.8 \mathrm{~Hz}, 2 \mathrm{H}), 1.31(\mathrm{~s}, 6 \mathrm{H}) .{ }^{13} \mathrm{C} \mathrm{NMR} 75 \mathrm{MHz}$ $\left(\mathrm{DMSO}-d_{6}\right) \delta(\mathrm{ppm}): 172.5,170.1,139.6,128.1,126.8,126.5,52.3,48.2,23.2 . \mathrm{HRMS} \mathrm{m} / \mathrm{z}$ calculated for $\mathrm{C}_{12} \mathrm{H}_{17} \mathrm{~N}_{2} \mathrm{O}_{3}[\mathrm{M}+\mathrm{H}]^{+}:$237.1239. Found: 237.1247 .

N-Benzyl-1-(hydroxycarbamoyl)cyclopropanecarboxamide (36). Obtained following the general procedure $\mathbf{C}$ from commercial 1,1-diethyl cyclopropane-1,1-dicarboxylate. Colorless oil (0.02 g, 4\%). Purity 99\%. $\mathrm{t}_{\mathrm{R}, \mathrm{LCMS}}=1.73 \mathrm{~min} . \mathrm{MS}(\mathrm{ESI}-): \mathrm{m} / \mathrm{z}=233[\mathrm{M}-\mathrm{H}]^{-}, \mathrm{MS}(\mathrm{ESI}+): \mathrm{m} / \mathrm{z}$ $=235[\mathrm{M}+\mathrm{H}]^{+} .{ }^{1} \mathrm{H}$ NMR $300 \mathrm{MHz}\left(\mathrm{CD}_{3} \mathrm{OD}-d_{4}\right) \delta(\mathrm{ppm}): 8.54(\mathrm{~s}, 1 \mathrm{H}), 7.34-7.21(\mathrm{~m}, 5 \mathrm{H}), 4.40$ $(\mathrm{s}, 2 \mathrm{H}), 1.40-1.28(\mathrm{ddd}, J=5.9 \mathrm{~Hz}, J=8.7 \mathrm{~Hz}, J=19.4 \mathrm{~Hz}, 4 \mathrm{H}) .{ }^{13} \mathrm{C}$ NMR $75 \mathrm{MHz}\left(\mathrm{CD}_{3} \mathrm{OD}-\right.$ $\left.d_{4}\right) \delta(\mathrm{ppm}): 172.0,170.0,139.8,129.4,128.4,128.2,44.4,28.4,15.5$. HRMS $\mathrm{m} / \mathrm{z}$ calculated for $\mathrm{C}_{12} \mathrm{H}_{15} \mathrm{~N}_{2} \mathrm{O}_{3}[\mathrm{M}+\mathrm{H}]^{+}:$235.1083. Found: 235.1092.

2-Benzyl-N-[(4-fluorophenyl)methyl]-3-(hydroxyamino)-3-oxo-propanamide (39). Obtained following the general procedure $\mathbf{C}$ from commercial 1,3-diethyl 2-benzylpropanedioate. Light yellow crystals $(0.046 \mathrm{~g}, 4 \%)$. Purity $97 \%$. mp: $185^{\circ} \mathrm{C} . \mathrm{t}_{\mathrm{R}, \mathrm{LCMS}}=2.63 \mathrm{~min} . \mathrm{MS}(\mathrm{ESI}-): \mathrm{m} / \mathrm{z}=$ $315[\mathrm{M}-\mathrm{H}]^{-}, \mathrm{MS}(\mathrm{ESI}+): \mathrm{m} / z=317[\mathrm{M}+\mathrm{H}]^{+} .{ }^{1} \mathrm{H}$ NMR $300 \mathrm{MHz}\left(\mathrm{CD}_{3} \mathrm{OD}-d_{4}\right) \delta(\mathrm{ppm}): 7.25-$ $7.19(\mathrm{~m}, 5 \mathrm{H}), 7.13-7.09(\mathrm{~m}, 2 \mathrm{H}), 7.00-6.94(\mathrm{~m}, 2 \mathrm{H}), 4.36(\mathrm{~d}, J=15.0 \mathrm{~Hz}, 1 \mathrm{H}), 4.23(\mathrm{~d}, J=15.0$ $\mathrm{Hz}, 1 \mathrm{H}), 3.33(\mathrm{t}, J=7.8 \mathrm{~Hz}, 1 \mathrm{H}), 3.15(\mathrm{~d}, J=7.8 \mathrm{~Hz}, 2 \mathrm{H}) .{ }^{13} \mathrm{C} \mathrm{NMR} 75 \mathrm{MHz}\left(\mathrm{CD}_{3} \mathrm{OD}-d_{4}\right) \delta$ (ppm): 168.7, 165.0, $161.7\left(\mathrm{~d}, J_{C F}=22.4 \mathrm{~Hz}\right), 139.3,135.6\left(\mathrm{~d}, J_{C F}=2.3 \mathrm{~Hz}\right), 130.3\left(\mathrm{~d}, J_{C F}=\right.$ 8.4 Hz), 130.0, 129.5, 127.7, $116.2\left(\mathrm{~d}, J_{C F}=22.4 \mathrm{~Hz}\right), 54.7,43.4,37.2 . \mathrm{HRMS} m / z$ calculated for $\mathrm{C}_{17} \mathrm{H}_{18} \mathrm{FN}_{2} \mathrm{O}_{3}[\mathrm{M}+\mathrm{H}]^{+}:$317.1301. Found: 317.1303 . 
2-Benzyl-3-(hydroxyamino)-3-oxo-N-(4-pyridylmethyl)propanamide (43). Obtained following the general procedure $\mathbf{C}$ from commercial 1,3-diethyl 2-benzylpropanedioate. White powder (0.080 g, 22\%). Purity 98\%. mp: $204{ }^{\circ} \mathrm{C} \cdot \mathrm{t}_{\mathrm{R}, \mathrm{LCMS}}=1.37 \mathrm{~min} . \mathrm{MS}(\mathrm{ESI}-): \mathrm{m} / z=298[\mathrm{M}-\mathrm{H}]^{-}, \mathrm{MS}$ (ESI+): $m / z=300[\mathrm{M}+\mathrm{H}]^{+} .{ }^{1} \mathrm{H}$ NMR $300 \mathrm{MHz}\left(\mathrm{CD}_{3} \mathrm{OD}-d_{4}\right) \delta(\mathrm{ppm}): 8.37(\mathrm{dd}, J=1.5 \mathrm{~Hz}, J=$ $4.5 \mathrm{~Hz}, 2 \mathrm{H}), 7.28-7.23(\mathrm{~m}, 5 \mathrm{H}), 7.11(\mathrm{dd}, J=1.5 \mathrm{~Hz}, J=4.5 \mathrm{~Hz}, 2 \mathrm{H}), 4.46(\mathrm{~d}, J=16.5 \mathrm{~Hz}$, $1 \mathrm{H}), 4.31(\mathrm{~d}, J=16.5 \mathrm{~Hz}, 1 \mathrm{H}), 3.40(\mathrm{t}, J=7.8 \mathrm{~Hz}, 1 \mathrm{H}), 3.19(\mathrm{~d}, J=7.8 \mathrm{~Hz}, 2 \mathrm{H}) .{ }^{13} \mathrm{C}$ NMR 75 $\mathrm{MHz}\left(\mathrm{CD}_{3} \mathrm{OD}-d_{4}\right) \delta(\mathrm{ppm}): 171.3,168.6,150.5,149.9,139.3,130.1,129.6,127.8,123.6,54.7$, 42.9, 36.9. HRMS $m / z$ calculated for $\mathrm{C}_{16} \mathrm{H}_{18} \mathrm{~N}_{3} \mathrm{O}_{3}[\mathrm{M}+\mathrm{H}]^{+}:$300.1348. Found: 300.1361 .

1-Benzoylpyrrolidine-3-carbohydroxamic acid (44). To a solution of commercial O-1-tert-butyl O-3-methyl pyrrolidine-1,3-dicarboxylate ( $0.200 \mathrm{~g}, 0.87 \mathrm{mmol}, 1$ equiv) in anhydrous DCM (2 $\mathrm{mL}, 0.43 \mathrm{M})$ was added dropwise TFA $(0.513 \mathrm{~mL}, 6.97 \mathrm{mmol}, 8$ equiv $)$ at $0{ }^{\circ} \mathrm{C}$. The cooling bath was removed and the mixture was stirred $1 \mathrm{~h}$ at room temperature. Then DCM was evaporated in vacuo, the residue was dissolved in DCM and evaporated again under vacuum (5 cycles) to eliminate TFA. Methyl pyrrolidine-3-carboxylate $70(0.112 \mathrm{~g}, 99 \%)$ was obtained as yellow oil. To a solution of amine 70 (0.112 g, $0.86 \mathrm{mmol}, 1$ equiv) and DIPEA (0.161 mL, $0.95 \mathrm{mmol}, 1.1$ equiv), in anhydrous DCM $(2 \mathrm{~mL}, 0.43 \mathrm{M})$ at $0{ }^{\circ} \mathrm{C}$ was added dropwise benzoyl chloride ( $0.101 \mathrm{~mL}, 0.87 \mathrm{mmol}, 1$ equiv). The ice bath was removed and the solution was stirred $2 \mathrm{~h}$ to $\mathrm{rt}$. Solvent was evaporated under vacuum and the residue was partitioned between aqueous $\mathrm{HCl}(1 \mathrm{M})$ and EtOAc. The aqueous phase was extracted two times with EtOAc and the three organic layers were pooled, dried over $\mathrm{MgSO}_{4}$ and evaporated to give a yellow crude product which was purified by flash column chromatography cyclohexane/EtOAc. Pure methyl 1-benzoylpyrrolidine-3-carboxylate 44a $(0.167 \mathrm{~g}, 62 \%)$ was obtained as colorless oil. $\mathrm{t}_{\mathrm{R}, \mathrm{LCMS}}=$ $2.45 \mathrm{~min}$. MS (ESI+): $\mathrm{m} / z=234[\mathrm{M}+\mathrm{H}]^{+}$. To a solution of $44 \mathbf{a}(0.167 \mathrm{~g}, 0.71 \mathrm{mmol}, 1$ equiv) in $\mathrm{MeOH}(2.97 \mathrm{~mL}, 0.24 \mathrm{M})$ was added a solution of aqueous hydroxylamine $50 \%(2.97 \mathrm{~mL}$, aq. $\mathrm{NH}_{2} \mathrm{OH} / \mathrm{MeOH} 1: 1$ (v:v)) and $\mathrm{KCN}(0.023 \mathrm{~g}, 0.35 \mathrm{mmol}, 0.5$ equiv). The solution was 
stirred overnight at room temperature (convenience). Crude product was concentrated under vacuum and an aqueous workup was performed using $\mathrm{H}_{2} \mathrm{O} / \mathrm{EtOAc}(1: 50$ (v:v)) then the aqueous layer was dissolved in a mixture of aqueous $15 \% \mathrm{KOH} / \mathrm{NaClO} 75: 25$ (v:v) and discarded in an appropriate waste tank. The organic layer was evaporated under vacuum and purified by preparative HPLC using a linear acetonitrile/water gradient, containing ammoniumacetate/formic acid buffer $(\mathrm{pH}=3.8)$, starting with $\mathrm{H}_{2} \mathrm{O} 98 \%$ to reach acetonitrile $100 \%$ in 25min. Pure hydroxamic acid 44 was obtained as colorless oil (0.027 g, 16\%). Purity 97\%. $\mathrm{t}_{\mathrm{R}, \mathrm{LCMS}}=1.37 \mathrm{~min} . \mathrm{MS}(\mathrm{ESI}-): \mathrm{m} / z=233[\mathrm{M}-\mathrm{H}]^{-}, \mathrm{MS}(\mathrm{ESI}+): \mathrm{m} / z=235[\mathrm{M}+\mathrm{H}]^{+} .{ }^{1} \mathrm{H} \mathrm{NMR}$ $300 \mathrm{MHz}\left(\mathrm{CD}_{3} \mathrm{OD}-d_{4}\right) \delta(\mathrm{ppm}): 8.52(\mathrm{~s}, 1 \mathrm{H}), 7.54-7.50(\mathrm{~m}, 2 \mathrm{H}), 7.49-7.43(\mathrm{~m}, 3 \mathrm{H}), 3.85-3.37$ (m, 2H), 3.69-3.50 (m, 2H), $2.94(\mathrm{t}, J=7.6 \mathrm{~Hz}, 1 \mathrm{H}), 2.23-2.17(\mathrm{~m}, 1 \mathrm{H}), 2.11(\mathrm{dd}, J=6.8 \mathrm{~Hz}, J$ $=13.8 \mathrm{~Hz}, 1 \mathrm{H}) .{ }^{13} \mathrm{C}$ NMR $75 \mathrm{MHz}\left(\mathrm{CD}_{3} \mathrm{OD}-d_{4}\right) \delta(\mathrm{ppm}): 172.3,171.6,137.7,131.4,129.6$, 128.1, 42.7, 41.1, 31.0, 29.2. HRMS $m / z$ calculated for $\mathrm{C}_{12} \mathrm{H}_{15} \mathrm{~N}_{2} \mathrm{O}_{3}[\mathrm{M}+\mathrm{H}]^{+}:$235.1083. Found: 235.1114

N-[3-(Hydroxyamino)-3-oxo-2-(1-piperidyl)propyl]benzamide (45). To a solution of commercial methyl 3-amino-2-(1-piperidyl)propanoate 74 (0.437 g, $2.34 \mathrm{mmol}, 1.1$ equiv) and DIPEA (0.396 mL, $2.32 \mathrm{mmol}, 1.1$ equiv) in anhydrous DCM at $0{ }^{\circ} \mathrm{C}$ was added benzoyl chloride $(0.248 \mathrm{~mL}, 2.13 \mathrm{mmol}, 1$ equiv). The solution was allowed to warm at room temperature and stirred $1 \mathrm{~h}$. Then DCM was evaporated under pressure and the residue was partitioned between aqueous $\mathrm{HCl} 1 \mathrm{M}$ and EtOAc. The aqueous layer washed twice by EtOAc and basified with $\mathrm{K}_{2} \mathrm{CO}_{3}$. Then the desired product was extracted by EtOAc. Solvent was evaporated in vacuo to afford methyl 3-benzamido-2-(1-piperidyl)propanoate 45a as yellow oil $(0.257 \mathrm{~g}, 41 \%) \cdot \mathrm{t}_{\mathrm{R}, \mathrm{LCMS}}=1.86 \mathrm{~min} . \mathrm{MS}(\mathrm{ESI}+): \mathrm{m} / z=291[\mathrm{M}+\mathrm{H}]^{+}$. To a solution of 45a $(0.100$ $\mathrm{g}, 0.35 \mathrm{mmol}, 1$ equiv) in $\mathrm{MeOH}(1.43 \mathrm{~mL}, 0.25 \mathrm{M})$ was added a solution of aqueous hydroxylamine 50\% (1.43 mL, aq. $\mathrm{NH}_{2} \mathrm{OH} / \mathrm{MeOH} 1: 1$ (v:v)) and $\mathrm{KCN}(0.011 \mathrm{~g}, 0.17 \mathrm{mmol}$, 0.5 equiv). The mixture was stirred overnight at room temperature (convenience). Crude 
product was concentrated under vacuum and an aqueous workup was performed using $\mathrm{H}_{2} \mathrm{O} /$ EtOAc (1:50 (v:v)) then the aqueous layer was dissolved in a mixture of aqueous $15 \%$ $\mathrm{KOH} / \mathrm{NaClO}$ 75:25 (v:v) and discarded in an appropriate waste tank. The organic layer was evaporated under vacuum and purified by preparative HPLC using a linear acetonitrile/water gradient, containing ammonium-acetate/formic acid buffer $(\mathrm{pH}=9.2)$, starting with $\mathrm{H}_{2} \mathrm{O} 98 \%$ to reach acetonitrile $100 \%$ in $25 \mathrm{~min}$. Pure hydroxamic acid $\mathbf{4 5}$ was obtained as brown solid (0.029 g, 29\%). Purity 98\%. mp: $93{ }^{\circ} \mathrm{C} . \mathrm{t}_{\mathrm{R}, \mathrm{LCMS}}=1.48 \mathrm{~min} . \mathrm{MS}(\mathrm{ESI}-): \mathrm{m} / z=290[\mathrm{M}-\mathrm{H}]^{-}, \mathrm{MS}$ (ESI+): $m / z=292[\mathrm{M}+\mathrm{H}]^{+} .{ }^{1} \mathrm{H}$ NMR $300 \mathrm{MHz}\left(\mathrm{CD}_{3} \mathrm{OD}-d_{4}\right) \delta(\mathrm{ppm}): 8.42$ (br s, $\left.1 \mathrm{H}\right), 7.88-7.78$ $(\mathrm{d}, J=7.2 \mathrm{~Hz}, 2 \mathrm{H}), 7.56-7.42(\mathrm{~m}, 3 \mathrm{H}), 3.80(\mathrm{dd}, J=6.2 \mathrm{~Hz}, J=13.2 \mathrm{~Hz}, 1 \mathrm{H}), 3.62(\mathrm{dd}, J=7.8$ $\mathrm{Hz}, J=13.2 \mathrm{~Hz}, 1 \mathrm{H}), 2.72-2.67(\mathrm{q}, J=5.4 \mathrm{~Hz}, J=9.2 \mathrm{~Hz}, 4 \mathrm{H}), 1.62(\mathrm{~m}, 4 \mathrm{H}), 1.46-1.51(\mathrm{q}, J=$ $5.4 \mathrm{~Hz}, J=11.1 \mathrm{~Hz}, 2 \mathrm{H}) .{ }^{13} \mathrm{C} \mathrm{NMR} 75 \mathrm{MHz}\left(\mathrm{CD}_{3} \mathrm{OD}-d_{4}\right) \delta(\mathrm{ppm}): 170.4,168.9,135.6,132.8$, 129.6, 128.3, 66.3, 42.5, 39.5, 27.0, 25.3. HRMS $m / z$ calculated for $\mathrm{C}_{15} \mathrm{H}_{22} \mathrm{~N}_{3} \mathrm{O}_{3}[\mathrm{M}+\mathrm{H}]^{+}$: 292.1661. Found: 292.1693.

(S)-2-Benzenesulfonylamino-N-hydroxy-3-methyl-butyramide (46). Obtained following the general procedure B from 46b. Pink solid (0.080 g, 12\%). Purity 99\%. mp: $160{ }^{\circ} \mathrm{C} . \mathrm{t}_{\mathrm{R}, \mathrm{LCMS}}$ $=1.80 \mathrm{~min} . \mathrm{MS}(\mathrm{ESI}+): m / z=273[\mathrm{M}+\mathrm{H}]^{+} .{ }^{1} \mathrm{H}$ NMR $300 \mathrm{MHz}\left(\mathrm{DMSO}-d_{6}\right) \delta(\mathrm{ppm}): 10.49(\mathrm{br}$ s, 1H), 8.77 (br s, 1H), $7.92(\mathrm{~d}, J=9.0 \mathrm{~Hz}, 1 \mathrm{H}), 7.78-7.74(\mathrm{~m}, 2 \mathrm{H}), 7.62-7.51(\mathrm{~m}, 3 \mathrm{H}), 3.28(\mathrm{t}$, $J=8.4 \mathrm{~Hz}, 1 \mathrm{H}), 1.78-1.71(\mathrm{~m}, 1 \mathrm{H}), 0.73(\mathrm{~d}, J=6.6 \mathrm{~Hz}, 3 \mathrm{H}), 0.70(\mathrm{~d}, J=6.6 \mathrm{~Hz}, 3 \mathrm{H}) .{ }^{13} \mathrm{C} \mathrm{NMR}$ $75 \mathrm{MHz}\left(\mathrm{DMSO}-d_{6}\right) \delta(\mathrm{ppm}): 167.1,142.0,132.6,129.3,126.8,60.2,31.2,19.4,19.0$. HRMS $m / z$ calculated for $\mathrm{C}_{11} \mathrm{H}_{17} \mathrm{~N}_{2} \mathrm{O}_{4} \mathrm{~S}[\mathrm{M}+\mathrm{H}]^{+}:$273.0909. Found: 273.0898 .

(S)-2-Benzenesulfonylamino-N-hydroxy-3-phenyl-propionamide (47). Obtained following the general procedure B from 47b. White powder (0.020 g, 11\%). Purity 97\%. mp: $97{ }^{\circ} \mathrm{C}$. $\mathrm{t}_{\mathrm{R}, \mathrm{LCMS}}$ $=2.47 \mathrm{~min} . \mathrm{MS}(\mathrm{ESI}+): \mathrm{m} / z=321[\mathrm{M}+\mathrm{H}]^{+} .{ }^{1} \mathrm{H}$ NMR $300 \mathrm{MHz}$ (acetone- $\left.d_{6}\right) \delta(\mathrm{ppm}): 7.71-7.54$ (m, 5H), 7.48-7.10 (m, 5H), 3.96-3.90 (m, 1H), $2.75(\mathrm{dd}, J=7.5 \mathrm{~Hz}, J=13.5 \mathrm{~Hz}, 2 \mathrm{H}) .{ }^{13} \mathrm{C}$ 
NMR 75 MHz (acetone- $\left.d_{6}\right) \delta(\mathrm{ppm}): 166.9,141.2,136.6,132.3,129.3,128.9,128.2,126.7$, 126.6, 55.9, 38.9. HRMS $m / z$ calculated for $\mathrm{C}_{15} \mathrm{H}_{17} \mathrm{~N}_{2} \mathrm{O}_{4} \mathrm{~S}[\mathrm{M}+\mathrm{H}]^{+}:$321.0909. Found: 321.0916. (R)-2-(Benzenesulfonyl-benzyl-amino)-N-hydroxy-3-methyl-butyramide

(48). Obtained following the general procedure $\mathbf{B}$ from 48a. Colorless oil $(0.02 \mathrm{~g}, 4 \%)$. Purity $99 \%$. $\mathrm{t}_{\mathrm{R}, \mathrm{LCMS}}=$ $2.92 \min . \mathrm{MS}(\mathrm{ESI}+): \mathrm{m} / z=363[\mathrm{M}+\mathrm{H}]^{+} .{ }^{1} \mathrm{H}$ NMR $300 \mathrm{MHz}$ (acetone- $\left.d_{6}\right) \delta(\mathrm{ppm}): 7.71-7.68$ $(\mathrm{m}, 2 \mathrm{H}), 7.58-7.52(\mathrm{~m}, 1 \mathrm{H}), 7.46-7.40(\mathrm{~m}, 4 \mathrm{H}), 7.21-7.19(\mathrm{~m}, 3 \mathrm{H}), 4.77(\mathrm{~s}, 2 \mathrm{H}), 3.94(\mathrm{~d}, J=$ $10.8 \mathrm{~Hz}, 1 \mathrm{H}), 2.05(\mathrm{~m}, 1 \mathrm{H}), 0.79(\mathrm{~d}, J=6.6 \mathrm{~Hz}, 3 \mathrm{H}), 0.79(\mathrm{~d}, J=6.6 \mathrm{~Hz}, 3 \mathrm{H}) .{ }^{13} \mathrm{C} \mathrm{NMR} 75$ MHz (acetone- $\left.d_{6}\right) \delta(\mathrm{ppm}): 166.2,141.1,137.9,132.3,129.2,128.7,127.8,127.1,127.0,63.8$, 48.1, 26.6, 18.9, 18.6. HRMS $m / z$ calculated for $\mathrm{C}_{18} \mathrm{H}_{23} \mathrm{~N}_{2} \mathrm{O}_{4} \mathrm{~S}[\mathrm{M}+\mathrm{H}]^{+}$: 363.1379. Found: 363.1372 .

(R)-2-(Benzenesulfonyl-benzyl-amino)-3-phenyl-N-hydroxy-propionamide (49). Obtained following the general procedure $\mathbf{B}$ from $49 \mathrm{~b}$. Colorless oil $(0.020 \mathrm{~g}, 4 \%)$. Purity $98 \%$. $\mathrm{t}_{\mathrm{R}, \mathrm{LCMS}}=$ 3.07 min. MS (ESI+): $m / z=411[\mathrm{M}+\mathrm{H}]^{+} .{ }^{1} \mathrm{H}$ NMR $300 \mathrm{MHz}$ (acetone- $\left.d_{6}\right) \delta(\mathrm{ppm}): 7.82-7.79$ (m, 2H), 7.61 (t, $J=7.5 \mathrm{~Hz}, 1 \mathrm{H}), 7.52(\mathrm{t}, J=7.5 \mathrm{~Hz}, 2 \mathrm{H}), 7.39$ (d, $J=6.6 \mathrm{~Hz}, 2 \mathrm{H}), 7.27-7.15$ $(\mathrm{m}, 6 \mathrm{H}), 7.03-7.01(\mathrm{~m}, 2 \mathrm{H}), 4.81(\mathrm{~s}, 2 \mathrm{H}), 4.56(\mathrm{dd}, J=4.8 \mathrm{~Hz}, J=10.2 \mathrm{~Hz}, 1 \mathrm{H}), 3.14(\mathrm{dd}, J=$ 10.2 Hz, $J=13.2 \mathrm{~Hz}, 1 \mathrm{H}), 2.60(\mathrm{dd}, J=4.8 \mathrm{~Hz}, J=13.2 \mathrm{~Hz}, 1 \mathrm{H}) .{ }^{13} \mathrm{C}$ NMR $75 \mathrm{MHz}$ (acetone$\left.d_{6}\right) \delta(\mathrm{ppm}): 165.5,140.5,138.7,136.7,132.7,129.2,129.0,128.3,128.2,127.9,127.2,126.9$, 126.6, 58.8, 48.3, 37.1. HRMS $m / z$ calculated for $\mathrm{C}_{22} \mathrm{H}_{23} \mathrm{~N}_{2} \mathrm{O}_{4} \mathrm{~S}[\mathrm{M}+\mathrm{H}]^{+}$: 411.1379. Found: 411.1395 .

4-(Benzenesulfonamido)tetrahydropyran-4-carbohydroxamic acid (50). To a solution of commercial methyl 4-aminooxane-4-carboxylate $(0.105 \mathrm{~g}, 0.66 \mathrm{mmol}, 1$ equiv) in pyridine (0.942 mL, 0.7 M) was added dropwise liquid benzenesulfonyl chloride $(0.101 \mathrm{~mL}, 0.79 \mathrm{mmol}$, 1.2 equiv). This solution was stirred $2 \mathrm{~h}$ at room temperature (starts light yellow then becomes dark red). The mixture was partitioned between EtOAc and aq. $\mathrm{HCl} 1 \mathrm{M}$ and the organic phase was washed once again with aq. $\mathrm{HCl} 1 \mathrm{M}$. Celite was added to the organic phase and EtOAc 
was evaporated under vacuum affording a solid deposit purified by flash column chromatography cyclohexane $100 \%$ to cyclohexane/EtOAc 1:1 (v:v). Colorless oil (0.179 g, 66\%). Purity 98\%. TLC cyclohexane $100 \% \mathrm{R}_{f}=0.05$. TLC cyclohexane/EtOAc 1:1 (v:v) $\mathrm{R}_{f}=$ 0.75. $\mathrm{t}_{\mathrm{R}, \mathrm{LCMS}}=2.12 \mathrm{~min} . \mathrm{MS}(\mathrm{ESI}+): \mathrm{m} / z=298[\mathrm{M}+\mathrm{H}]^{+}, \mathrm{MS}(\mathrm{ESI}+): \mathrm{m} / z=300[\mathrm{M}+\mathrm{H}]^{+} .{ }^{1} \mathrm{H}$ NMR $300 \mathrm{MHz}\left(\mathrm{CDCl}_{3}\right) \delta(\mathrm{ppm}):$ 7.87-7.84 (m, 2H), 7.57-7.47 (m, 3H), 3.60-3.56 (m, 4H), $3.47(\mathrm{~s}, 3 \mathrm{H}), 2.11-2.03(\mathrm{~m}, 2 \mathrm{H}), 1.91-1.85(\mathrm{~m}, 2 \mathrm{H}) .{ }^{13} \mathrm{C} \mathrm{NMR} 75 \mathrm{MHz}\left(\mathrm{CDCl}_{3}\right) \delta(\mathrm{ppm}): 172.8$, 141.1, 132.9, 129.2, 127.3, 63.0, 59.1, 52.6, 33.2. To a solution of methyl ester 50a $(0.018 \mathrm{~g}$, $0.06 \mathrm{mmol}, 1$ equiv) in $\mathrm{MeOH}(0.133 \mathrm{~mL}, 0.45 \mathrm{M})$ was added aqueous hydroxylamine $50 \%$ ( $0.133 \mathrm{~mL}, 1.98 \mathrm{mmol}, 33$ equiv) and solid $\mathrm{KCN}$ ( $0.001 \mathrm{~g}, 0.06 \mathrm{mmol}, 0.1$ equiv). The mixture was stirred $48 \mathrm{~h}$ (convenience) at room temperature. The crude product was concentrated under vacuum and the residue was dissolved in acetonitrile with some drops of acidic water (0.1\%formic acid) under the fume hood filtered and the solution was purified by preparative HPLC using a linear acetonitrile/water gradient, containing ammonium-acetate/formic acid buffer $(\mathrm{pH}=3.8)$, starting with $\mathrm{H}_{2} \mathrm{O} 98 \%$ to reach acetonitrile $100 \%$ in $25 \mathrm{~min}$. $\mathrm{CH}_{3} \mathrm{CN}$ was evaporated under vacuum $\left(37^{\circ} \mathrm{C}\right.$ under 148 mbar) and aqueous solution was sublimated affording $\mathbf{5 0}$ as a white powder $(0.011 \mathrm{~g}, 57 \%)$. Purity $95 \%$. $\mathrm{mp}: 61^{\circ} \mathrm{C} . \mathrm{t}_{\mathrm{R}, \mathrm{LCMS}}=1.57 \mathrm{~min} . \mathrm{MS}$ (ESI-): $m / z=299[\mathrm{M}-\mathrm{H}]^{-}, \mathrm{MS}(\mathrm{ESI}+): \mathrm{m} / z=301[\mathrm{M}+\mathrm{H}]^{+} .{ }^{1} \mathrm{H}$ NMR $300 \mathrm{MHz}\left(\mathrm{DMSO}-d_{6}\right) \delta$ (ppm): $10.40(\mathrm{~s}, 1 \mathrm{H}), 8.71(\mathrm{~s}, 1 \mathrm{H}), 7.81-7.78(\mathrm{~m}, 2 \mathrm{H}), 7.61-7.52(\mathrm{~m}, 3 \mathrm{H}), 3.40-3.24(\mathrm{~m}, 4 \mathrm{H})$, 1.87-1.76 (m, 4H). ${ }^{13} \mathrm{C}$ NMR 75 MHz (DMSO- $\left.d_{6}\right) \delta(\mathrm{ppm}): 169.4,143.1,132.1,128.9,126.2$, 62.4, 58.1, 32.8. HRMS m/z calculated for $\mathrm{C}_{12} \mathrm{H}_{17} \mathrm{~N}_{2} \mathrm{O}_{5} \mathrm{~S}[\mathrm{M}+\mathrm{H}]^{+}$: 301.0858 . Found: 301.0860. 2-(Benzenesulfonyl)-3,4-dihydro-1H-isoquinoline-3-carbohydroxamic acid (51). To a solution of commercial 1,2,3,4-tetrahydroisoquinoline-3-carboxylic acid (0.200 g, $0.94 \mathrm{mmol}, 1$ equiv) in anhydrous methanol $(3.12 \mathrm{~mL}, 0.3 \mathrm{M})$ under argon at $0{ }^{\circ} \mathrm{C}$ was added dropwise $\mathrm{SOCl}_{2}(0.204$ $\mathrm{mL}, 2.80 \mathrm{mmol}, 3$ equiv). The mixture was stirred at room temperature 10 days then the mixture was dissolved in EtOAc $(10 \mathrm{~mL})$ and washed with water. The aqueous phase was extracted 2 
times with EtOAc. Organic phases were pooled, dried over $\mathrm{MgSO}_{4}$ and evaporated under vacuum. Methyl ester product 79 was obtained as white powder $(0.120 \mathrm{~g}, 64 \%) \cdot \mathrm{t}_{\mathrm{R}, \mathrm{LCMS}}=1.53$ min. MS (ESI+): $m / z=192[\mathrm{M}+\mathrm{H}]{ }^{+} .{ }^{1} \mathrm{H}$ NMR $300 \mathrm{MHz}\left(\mathrm{DMSO}-d_{6}\right) \delta(\mathrm{ppm}): 7.25(\mathrm{~s}, 4 \mathrm{H})$, $4.50(\mathrm{~m}, 1 \mathrm{H}), 4.30(\mathrm{~s}, 2 \mathrm{H}), 3.79(\mathrm{~s}, 3 \mathrm{H}), 3.28(\mathrm{dd}, J=3.8 \mathrm{~Hz}, J=16.8 \mathrm{~Hz}, 1 \mathrm{H}), 3.17(\mathrm{~m}, 1 \mathrm{H})$. To a solution of secondary amine $79(0.120 \mathrm{~g}, 0.62 \mathrm{mmol}, 1$ equiv) in anhydrous DCM (2 mL, $0.3 \mathrm{M})$ at $0{ }^{\circ} \mathrm{C}$ was added liquid TEA $(0.254 \mathrm{~mL}, 1.88 \mathrm{mmol}, 3$ equiv $)$ and benzenesulfonyl chloride $(0.096 \mathrm{~mL}, 0.75 \mathrm{mmol}, 1.2$ equiv) then the cooling bath was removed and the solution was stirred $3 \mathrm{~h}$ at $\mathrm{rt}$. Solvent was evaporated under reduced pressure and the residue was dissolved in aqueous sat. $\mathrm{NaHCO}_{3}$ and EtOAc. The product was extracted 2 times with EtOAc, dried over $\mathrm{MgSO}_{4}$ and evaporated in vacuo. The residue was purified by flash column chromatography cyclohexane/ethyl acetate to afford the desired sulfonamide 51a as colorless oil $(0.048 \mathrm{~g}, 23 \%) \cdot \mathrm{t}_{\mathrm{R}, \mathrm{LCMS}}=2.97 \mathrm{~min}$. MS $(\mathrm{ESI}+): \mathrm{m} / z=332[\mathrm{M}+\mathrm{H}]^{+}$. To a solution of methyl ester $(0.023 \mathrm{~g}, 0.07 \mathrm{mmol}, 1$ equiv) in $\mathrm{MeOH}(0.298 \mathrm{~mL}, 0.23 \mathrm{M})$ was added a solution of aqueous hydroxylamine 50\% (0.298 mL, aq. $\left.\mathrm{NH}_{2} \mathrm{OH} / \mathrm{MeOH} 1: 1(\mathrm{v}: \mathrm{v})\right)$ and $\mathrm{KCN}(0.002 \mathrm{~g}, 0.03$ mmol, 0.5 equiv). The solution was stirred overnight at room temperature (convenience). Crude product was concentrated under vacuum and an aqueous workup was performed using $\mathrm{H}_{2} \mathrm{O} /$ EtOAc (1:50 (v:v)) then the aqueous layer was dissolved in a mixture of aqueous $15 \%$ $\mathrm{KOH} / \mathrm{NaClO} 75: 25$ (v:v) and discarded in an appropriate waste tank. The organic layer was evaporated under vacuum and purified by preparative HPLC using a linear acetonitrile/water gradient, containing ammonium-acetate/formic acid buffer $(\mathrm{pH}=3.8)$, starting with $\mathrm{H}_{2} \mathrm{O} 98 \%$ to reach acetonitrile $100 \%$ in $25 \mathrm{~min}$. Pure hydroxamic acid $\mathbf{5 1}$ was obtained as white powder (0.009 g, 41\%). Purity 99\%. mp: $116^{\circ} \mathrm{C} \cdot \mathrm{t}_{\mathrm{R}, \mathrm{LCMS}}=2.27 \mathrm{~min} . \mathrm{MS}(\mathrm{ESI}-): \mathrm{m} / z=331[\mathrm{M}-\mathrm{H}]^{-}, \mathrm{MS}$ (ESI+): $m / z=333[\mathrm{M}+\mathrm{H}]^{+} .{ }^{1} \mathrm{H}$ NMR $300 \mathrm{MHz}\left(\mathrm{CD}_{3} \mathrm{OD}-d_{4}\right) \delta(\mathrm{ppm}): 7.79(\mathrm{~m}, 2 \mathrm{H}), 7.61(\mathrm{tt}, J$ $=1.4 \mathrm{~Hz}, J=7.5 \mathrm{~Hz}, 1 \mathrm{H}), 7.46(\mathrm{tt}, J=1.4 \mathrm{~Hz}, J=7.5 \mathrm{~Hz}, 2 \mathrm{H}), 7.11-7.00(\mathrm{~m}, 4 \mathrm{H}), 4.55(\mathrm{~d}, J=$ $4.7 \mathrm{~Hz}, 2 \mathrm{H}), 4.47(\mathrm{t}, J=5.8 \mathrm{~Hz}, 1 \mathrm{H}), 3.01(\mathrm{dd}, J=5.6 \mathrm{~Hz}, J=15.5 \mathrm{~Hz}, 1 \mathrm{H}), 2.78(\mathrm{dd}, J=6.4$ 
$\mathrm{Hz}, J=15.5 \mathrm{~Hz}, 1 \mathrm{H}) .{ }^{13} \mathrm{C} \mathrm{NMR} 75 \mathrm{MHz}\left(\mathrm{CD}_{3} \mathrm{OD}-d_{4}\right) \delta(\mathrm{ppm}): 170.2,139.3,134.2,134.1$, $133.8,130.3,128.8,128.6,128.5,127.8,127.2,56.1,47.0,32.1$. HRMS $m / z$ calculated for $\mathrm{C}_{16} \mathrm{H}_{17} \mathrm{~N}_{2} \mathrm{O}_{4} \mathrm{~S}[\mathrm{M}+\mathrm{H}]^{+}:$333.0909. Found: 333.0928.

(E)-3-(2,4-Dichloro-phenyl)-N-hydroxy-acrylamide (52). Obtained following the general procedure B from 52b. White powder $(0.030 \mathrm{~g}, 6 \%)$. Purity $99 \% . \mathrm{mp}: 175{ }^{\circ} \mathrm{C} \cdot \mathrm{t}_{\mathrm{R}, \mathrm{LCMS}}=2.63$ min. MS (ESI+): $m / z=232[\mathrm{M}+\mathrm{H}]^{+} .{ }^{1} \mathrm{H}$ NMR $300 \mathrm{MHz}\left(\mathrm{DMSO}-d_{6}\right) \delta(\mathrm{ppm}): 10.89$ (br s, $\left.1 \mathrm{H}\right)$, $9.16($ br s, $1 \mathrm{H}), 7.73-7.64(\mathrm{~m}, 3 \mathrm{H}), 7.48(\mathrm{~d}, J=15.9 \mathrm{~Hz}, 1 \mathrm{H}), 6.53(\mathrm{~d}, J=15.9 \mathrm{~Hz}, 1 \mathrm{H}) .{ }^{13} \mathrm{C}$ NMR 75 MHz (DMSO-d $\left.d_{6}\right)(\mathrm{ppm}): 162.3,134.9,134.5,132.9,132.2,129.9,129.3,128.5$, 123.5. HRMS $m / z$ calculated for $\mathrm{C}_{9} \mathrm{H}_{8} \mathrm{NO}_{2} \mathrm{Cl}_{2}[\mathrm{M}+\mathrm{H}]^{+}:$: 231.9932. Found: 231.9935 .

(E)-3-Biphenyl-4-yl-N-hydroxy-acrylamide (53). Obtained following the general procedure $\mathbf{B}$ from commercial (2E)-3-\{[1,1'-biphenyl]-4-yl $\}$ prop-2-enoic acid. White powder $(0.110 \mathrm{~g}$, $38 \%$ ). Purity $99 \% . \mathrm{mp}: 168{ }^{\circ} \mathrm{C} . \mathrm{t}_{\mathrm{R}, \mathrm{LCMS}}=2.73 \mathrm{~min} . \mathrm{MS}(\mathrm{ESI}+): \mathrm{m} / z=240[\mathrm{M}+\mathrm{H}]^{+} .{ }^{1} \mathrm{H} \mathrm{NMR}$ $300 \mathrm{MHz}\left(\mathrm{DMSO}-d_{6}\right) \delta(\mathrm{ppm}): 10.78(\mathrm{~s}, 1 \mathrm{H}), 9.05$ (br s, 1H), 7.73-7.63 (m, 6H), 7.53-7.35 (m, 4H), $6.50(\mathrm{~d}, J=14.4 \mathrm{~Hz}, 1 \mathrm{H}) .{ }^{13} \mathrm{C} \mathrm{NMR} 75 \mathrm{MHz}\left(\mathrm{DMSO}-d_{6}\right) \delta(\mathrm{ppm}): 163.2,141.4,139.8$, 138.3, 134.4, 129.5, 128.6, 128.3, 127.6, 127.1, 119.6. HRMS $m / z$ calculated for $\mathrm{C}_{15} \mathrm{H}_{14} \mathrm{NO}_{2}$ $[\mathrm{M}+\mathrm{H}]^{+}:$240.1025. Found: 240.1007 .

(E)-N-Hydroxy-3-\{4[(phenylamino)sulfonyl]phenyl\}prop-2-enamide (54). Obtained following the general procedure B from 54b. Pink solid (0.080 g, 18\%). Purity 99\%. mp: $171{ }^{\circ} \mathrm{C}$. $\mathrm{t}_{\mathrm{R}, \mathrm{LCMS}}$ $=2.47 \mathrm{~min} . \mathrm{MS}(\mathrm{ESI}+): \mathrm{m} / z=319[\mathrm{M}+\mathrm{H}]^{+} .{ }^{1} \mathrm{H}$ NMR $300 \mathrm{MHz}\left(\mathrm{DMSO}-d_{6}\right) \delta(\mathrm{ppm}): 10.85(\mathrm{br}$ s, $1 \mathrm{H}), 10.32$ (br s, 1H), 9.12 (br s, 1H), 7.76-7.68 (m, 4H), $7.43(\mathrm{~d}, J=15.9 \mathrm{~Hz}, 1 \mathrm{H}), 7.24$ (t, $J$ $=7.5 \mathrm{~Hz}, 2 \mathrm{H}), 7.08(\mathrm{~d}, J=7.5 \mathrm{~Hz}, 1 \mathrm{H}), 7.00(\mathrm{t}, J=7.5 \mathrm{~Hz}, 2 \mathrm{H}), 6.52(\mathrm{~d}, J=15.9 \mathrm{~Hz}, 1 \mathrm{H}) .{ }^{13} \mathrm{C}$ NMR 75 MHz (DMSO-d $) \delta(\mathrm{ppm}): 162.5,140.1,139.5,138.0,136.9,129.6,128.5,127.7$, 124.7, 122.8, 120.6. HRMS $\mathrm{m} / z$ calculated for $\mathrm{C}_{15} \mathrm{H}_{15} \mathrm{~N}_{2} \mathrm{O}_{4} \mathrm{~S}[\mathrm{M}+\mathrm{H}]^{+}$: 319.0753. Found: 319.0764 . 
Obtained following the general procedure B from 55b. Yellow oil (0.22 g, 57\%). Purity 97\%. $\mathrm{t}_{\mathrm{R}, \mathrm{LCMS}}=2.19 \min . \mathrm{MS}(\mathrm{ESI}+): m / z=357[\mathrm{M}+\mathrm{H}]^{+} .{ }^{1} \mathrm{H}$ NMR $300 \mathrm{MHz}\left(\mathrm{DMSO}-d_{6}\right) \delta(\mathrm{ppm}):$ 9.50 (br s, 2H), $7.76(\mathrm{~s}, 1 \mathrm{H}), 7.60(\mathrm{~d}, J=15.9 \mathrm{~Hz}, 1 \mathrm{H}), 7.47-7.44(\mathrm{~m}, 2 \mathrm{H}), 6.45(\mathrm{~d}, J=15.9 \mathrm{~Hz}$, $1 \mathrm{H}), 3.35-3.30(\mathrm{~m}, 10 \mathrm{H}), 3.12-3.05(\mathrm{~m}, 4 \mathrm{H}), 2.89(\mathrm{t}, J=7.8 \mathrm{~Hz}, 2 \mathrm{H}), 1.82(\mathrm{~m}, 2 \mathrm{H}), 1.48(\mathrm{~m}$, 2H), $1.18(\mathrm{t}, J=7.8 \mathrm{~Hz}, 3 \mathrm{H}) .{ }^{13} \mathrm{C}$ NMR $75 \mathrm{MHz}\left(\mathrm{DMSO}-d_{6}\right) \delta(\mathrm{ppm}): 163.7,156.8,143.1$, $139.9,136.7,136.3,129.3,121.7,119.6,115.7,110.7,47.0,46.1,40.2,29.2,26.4,22.4,14.2$, 9.0. HRMS $m / z$ calculated for $\mathrm{C}_{20} \mathrm{H}_{31} \mathrm{~N}_{4} \mathrm{O}_{2}[\mathrm{M}+\mathrm{H}]^{+}:$359.2447. Found: 359.2447.

N-Hydroxy-3,3-diphenyl-acrylamide (56). Obtained following the general procedure $\mathbf{B}$ from 56b. White solid (0.44 g, 46\%). Purity: $99 \%$. $\mathrm{mp}: 134{ }^{\circ} \mathrm{C} . \mathrm{t}_{\mathrm{R}, \mathrm{LCMS}}=2.63 \mathrm{~min} . \mathrm{MS}(\mathrm{ESI}+): \mathrm{m} / \mathrm{z}$ $=240[\mathrm{M}+\mathrm{H}]^{+} .{ }^{1} \mathrm{H}$ NMR $300 \mathrm{MHz}\left(\mathrm{DMSO}-d_{6}\right) \delta(\mathrm{ppm}): 10.60(\mathrm{br} \mathrm{s}, 1 \mathrm{H}), 8.80(\mathrm{br} \mathrm{s}, 1 \mathrm{H}), 7.34-$ $7.13(\mathrm{~m}, 11 \mathrm{H}), 6.27$ (s, 1H). ${ }^{13} \mathrm{C}$ NMR $75 \mathrm{MHz}\left(\mathrm{DMSO}-d_{6}\right) \delta(\mathrm{ppm}): 163.2,150.1,141.9,139.3$, 129.1, 128.9, 128.1, 128.1. HRMS $m / z$ calculated for $\mathrm{C}_{15} \mathrm{H}_{14} \mathrm{NO}_{2}[\mathrm{M}+\mathrm{H}]^{+}$: 240.1025. Found: 240.1029.

\section{General Biology}

Ethylenediaminetetraacetic acid (EDTA), 5,5'-dithiobis(2-nitrobenzoic acid) (DTNB), phenylmethanesulfonyl fluoride (PMSF), bis-(4-nitrophenyl)-phosphate (BNPP), ethopropazine hydrochloride (profenamine), enalapril maleate salt, eucatropine hydrochloride and prasugrel were obtained from Sigma-Aldrich, tacrine hydrochloride from Tocris. Huprine 2 was obtained as previously described.35 Trandolapril was obtained from Sequoia Research Products. Solvents were from common sources and of LC-MS grade. Stock solutions of all compounds were prepared in methanol at a concentration of $1 \mathrm{mM}$. Rat plasma, and human plasma, mixed gender, were purchased from Seralab. Rat whole blood male and female were purchased from Charles River, France (SANOFAHEL005) and pooled upon reception. Rat and 
human liver microsomes and rat intestinal microsomes were purchased from Tebu-bio. Solvents were from common sources and of LC-MS grade.

\section{Plasma/ Whole Blood stabilities}

Plasma or whole blood incubations were performed in duplicate, at $37^{\circ} \mathrm{C}$, in Eppendorf tubes. The incubation contained $10 \mu \mathrm{M}$ test compound (1\% methanol) in rat or human plasma in a final volume of $0.5 \mathrm{~mL}$. Sampling points were taken at 0, 15, 30, 60, 120, 240, $360 \mathrm{~min}$ and reactions were terminated by adding ice-cold methanol containing $500 \mathrm{nM}$ internal standard (9 volumes). The samples were centrifuged for $10 \mathrm{~min}$ at $10000 \mathrm{~g}, 4{ }^{\circ} \mathrm{C}$ to pellet precipitated protein and the supernatant was transferred in Matrix tubes for LC-MS/MS analysis. Incubations with specific esterases inhibitors were performed in duplicate, at $37{ }^{\circ} \mathrm{C}$, in Eppendorf tubes. The incubation contained $10 \mu \mathrm{M}$ test compound (1\% methanol) in rat or human plasma and the appropriate esterase inhibitor (1.25 mM PMSF, 0.25 mM BNPP, $1 \mathrm{mM}$ DTNB, $0.05 \mathrm{mM}$ profenamine, $0.5 \mathrm{mM}$ EDTA or $0.5 \mathrm{mM}$ huprine2), in a final volume of 0.5 $\mathrm{mL}$. Sampling points were taken at $0,15,30,60,120,240,360 \mathrm{~min}$ and reactions were terminated by adding ice-cold methanol containing $500 \mathrm{nM}$ internal standard ( 9 volumes). The samples were centrifuged for $10 \mathrm{~min}$ at $10000 \mathrm{~g}, 4{ }^{\circ} \mathrm{C}$ to pellet precipitated protein and the supernatant was transferred in Matrix tubes for LC-MS/MS analysis. Control incubations were performed in duplicate, with methanol instead of the inhibitor compound. Each experiment included a reference compound tested in the same conditions and allowing the validation of the experiment: eucatropine $\left(10 \mu \mathrm{M}, \mathrm{t}_{1 / 2}=9 \mathrm{~min}\right.$, human plasma or whole blood $)$ and enalapril (10 $\mu \mathrm{M}, \mathrm{t}_{1 / 2}=13 \mathrm{~min}$, rat plasma or whole blood).

\section{Microsomal Stability}


Microsomal incubations were performed in duplicate, at $37^{\circ} \mathrm{C}$, in glass tubes. The incubation contained $1 \mu \mathrm{M}$ test compound ( $1 \%$ methanol) in rat liver microsomes, human liver microsomes or rat intestinal microsomes $(1 \mathrm{mg}$ of microsomal protein $/ \mathrm{mL})$ in a final volume of $0.25 \mathrm{~mL}$. Sampling points were taken at 0,15, 30, 60, $120 \mathrm{~min}$ and reactions were terminated by adding ice-cold methanol or acetonitrile containing $200 \mathrm{nM}$ internal standard (4 volumes). The samples were centrifuged for $10 \mathrm{~min}$ at $10000 \mathrm{~g}, 4^{\circ} \mathrm{C}$ to pellet precipitated microsomal protein and the supernatant was transferred in Matrix tubes for LC-MS/MS analysis. Control incubations were performed in triplicate, with denaturated microsomes with acetonitrile containing $200 \mathrm{nM}$ internal standard and sampling points were taken at $0 \mathrm{~min}$ and $120 \mathrm{~min}$ (to evaluate the compound chemical stability in the experimental conditions). Each experiment included a reference compound tested in the same conditions and allowing the validation of the experiment: trandolapril $\left(\mathrm{t}_{1 / 2}\right.$ human $=20 \mathrm{~min}, \mathrm{t}_{1 / 2}$ rat $=7 \mathrm{~min}, 1 \mu \mathrm{M}, \mathrm{CES} 1$ substrate $)$ for liver microsomes and prasugrel ( $\mathrm{t}_{1 / 2}$ rat $=1 \mathrm{~min}, 1 \mu \mathrm{M}$, CES2 substrate) for intestinal microsomes.

\section{LC-MS/MS analysis}

Samples analysis were performed on a liquid chromatography coupled to a triple quadrupole mass spectrometer (Aquity I Class - Xevo TQD, Waters, Les Ulis, France) with an electrospray ionisation source. Chromatographic separations were carried out using an Acquity BEH C18, $1,7 \mu \mathrm{m}, 50 \times 2.1 \mathrm{~mm}$ column (Waters) maintained at $40^{\circ} \mathrm{C}$. Mobile phase solvent A was $10 \mathrm{mM}$ ammonium acetate in water and solvent $\mathrm{B}$ was acetonitrile with $0,1 \%$ of formic acid. The following gradient was applied: $2 \%$ B during 10 s, 2-98\% B in 1'50; hold at $98 \%$ B for $30 \mathrm{~s}$; $98 \%-2 \% \mathrm{~B}$ in $5 \mathrm{~s} ; 2 \% \mathrm{~B}$ hold for 1 ' 30 . The injection volume was $1 \mu \mathrm{L}$ and the flow rate of 600 $\mu \mathrm{L} / \mathrm{min}$. The desolvation and cone gas flow were respectively 1200 and $50 \mathrm{~L} / \mathrm{h}$; the source temperature was $600^{\circ} \mathrm{C}$. The capillary and cone voltages, the collision energy and the observed MRM transitions were automatically optimized for each compound. 
Quantitation of each compound was achieved by conversion of the corresponding analyte/internal standard peak area ratios to percentage drug remaining, using the T0 ratio values as $100 \%$. The slope of the linear regression from log percentage remaining versus incubation time relationships (-k) was used in the conversion to in vitro $\mathrm{t}_{1 / 2}$ values by: in vitro $\mathrm{t}_{1 / 2}=-0.693 / \mathrm{k}$

\section{Statistical analysis}

Half-lives were calculated using Xlfit ${ }^{\mathrm{TM}}$ (IDBS Ltd). Data for Box-Whisker plots were calculated using Microsoft Excel. Univariate and multivariate statistical analysis was performed using SPSS v19 (IBM. Armonk. NY).

\section{AUTHOR INFORMATION}

\section{Corresponding Author}

* R.D.P.: phone +33 (0)320 964 948; e-mail: rebecca.deprez@univ-lille2.fr

ORCID Rebecca Deprez-Poulain orcid.org/0000-0002-3318-5297

\section{Author Contributions}

\# These authors contributed equally.

\section{ACKNOWLEDGMENT}

We are grateful to the institutions that support our laboratory: INSERM, Université de Lille, Institut Pasteur de Lille. The authors thank Agathe Urban, Matthias Borms, Thomas Bosio for technical assistance. Foundation pour la Recherche Médicale (grant DCM20111223046) and Agence Nationale de la recherche (grant ANR-11-JS07-015-01) are thanked for funding. Paul Hermant is recipient of a doctoral fellowship of Conseil Régional Nord-Pas de Calais and INSERM. NMR acquisitions were done at the Laboratoire d'Application de Résonance Magnétique Nucléaire (LARMN), Lille, France. Rebecca Deprez-Poulain is a member of the Institut Universitaire de France. 


\section{ABBREVIATIONS}

AChE, acetylcholinesterase; AGG, aggrecanase; aq., aqueous; ArE, arylesterase; BNPP, bis(4-nitrophenyl)-phosphate; BoNTA, neurotoxin A metalloprotease of bacterium Clostridium botulinum; BuChE, butyrylcholinesterase; CES1, carboxylesterase-1; CES2, carboxylesterase2; CNS, central nervous system; DIPEA, N,N-diisopropylethylamine; DMF, $N, N$ dimethylformamide; DTNB, 5,5'-dithiobis(2-nitrobenzoic acid) ; EDCI, $\quad N$-(3dimethylaminopropyl)- $N$ '-ethylcarbodiimide hydrochloride; EDTA, ethylenediaminetetraacetic acid; equiv, equivalent; EtOH, ethanol; GCPII, glutamate carboxypeptidase II; HBTU, 2-(1H-benzotriazol-1-yl)-1,1,3,3-tetramethyluronium hexafluorophosphate; $\mathrm{HCV}$, hepatitis $\mathrm{C}$ virus; HER-2, human epidermal growth factor receptor 2; HIV, human immunodeficiency virus; HOBt, hydroxybenzotriazole; IDE, insulin-degrading enzyme; LDA, lithium diisopropylamide; $\quad$ LpxC, UDP-3-O-(R-3-hydroxymyristoyl)- $N$-acetylglucosamine deacetylase; $\mathrm{MeCN}$, acetonitrile; $\mathrm{MeOH}$, methanol; MMP, matrix metalloprotease; OR, Oddratio ; PDF, peptide deformylase; PfAM1, Plasmodium falciparum aminopeptide-1; PMSF, phenylmethanesulfonyl fluoride; PON-1, paraoxonase-1; profenamine, ethopropazine hydrochloride; ROCK, rho kinase; SA, serum albumin; TACE, tumor necrosis factor- $\alpha-$ converting enzyme; TFA, trifluoroacetic acid; THF, tetrahydrofuran; TIS, triisopropylsilane.

\section{SUPPORTING INFORMATION}

The Supporting Information is available free of charge on the ACS Publications website at DOI: XXX. Supplementary figures; Supplementary tables; Synthesis of intermediates; Molecular docking and scoring methods; (PDF).

\section{References}


1 Sieber, S. A.; Niessen, S.; Hoover, H. S.; Cravatt, B. F. Proteomic Profiling of Metalloprotease Activities with Cocktails of Active-Site Probes. Nat. Chem. Biol. 2006, 2, 274281.

2 Marmion, C. J.; Griffith, D.; Nolan, K. B. Hydroxamic Acids - an Intriguing Family of Enzyme Inhibitors and Biomedical Ligands. Eur. J. Inorg. Chem. 2004, 2004, 3003-3016.

3 Boularot, A.; Giglione, C.; Petit, S.; Duroc, Y.; Alves de Sousa, R.; Larue, V.; Cresteil, T.; Dardel, F.; Artaud, I.; Meinnel, T. Discovery and Refinement of a New Structural Class of Potent Peptide Deformylase Inhibitors. J. Med. Chem. 2007, 50, 10-20.

4 Seki, H.; Pellett, S.; Šilhár, P.; Stowe, G. N.; Blanco, B.; Lardy, M. A.; Johnson, E. A.; Janda, K. D. Synthesis/Biological Evaluation of Hydroxamic Acids and Their Prodrugs as Inhibitors for Botulinum Neurotoxin a Light Chain. Bioorg. Med. Chem. 2014, 22, 1208-1217.

5 McAllister, L. A.; Montgomery, J. I.; Abramite, J. A.; Reilly, U.; Brown, M. F.; Chen, J. M.; Barham, R. A.; Che, Y.; Chung, S. W.; Menard, C. A.; Mitton-Fry, M.; Mullins, L. M.; Noe, M. C.; O'Donnell, J. P.; Oliver Iii, R. M.; Penzien, J. B.; Plummer, M.; Price, L. M.; Shanmugasundaram, V.; Tomaras, A. P.; Uccello, D. P. Heterocyclic Methylsulfone Hydroxamic Acid Lpxc Inhibitors as Gram-Negative Antibacterial Agents. Bioorg. Med. Chem. Lett. 2013, 22, 6832-6838.

6 Ai, T.; Xu, Y.; Qiu, L.; Geraghty, R. J.; Chen, L. Hydroxamic Acids Block Replication of Hepatitis C Virus. J. Med. Chem. 2015, 58, 785-800.

7 Plewe, M. B.; Butler, S. L.; R. Dress, K.; Hu, Q.; Johnson, T. W.; Kuehler, J. E.; Kuki, A.; Lam, H.; Liu, W.; Nowlin, D.; Peng, Q.; Rahavendran, S. V.; Tanis, S. P.; Tran, K. T.; Wang, H.; Yang, A.; Zhang, J. Azaindole Hydroxamic Acids Are Potent Hiv-1 Integrase Inhibitors. J. Med. Chem. 2009, 52, 7211-7219.

8 (a) Deprez-Poulain, R.; Flipo, M.; Piveteau, C.; Leroux, F.; Dassonneville, S.; Florent, I.; Maes, L.; Cos, P.; Deprez, B. Structure-Activity Relationships and Blood Distribution of 
Antiplasmodial Aminopeptidase-1 Inhibitors. J. Med. Chem. 2012, 55, 10909-10917. (b)

Mistry, S. N.; Drinkwater, N.; Ruggeri, C.; Sivaraman, K. K.; Loganathan, S.; Fletcher, S.; Drag, M.; Paiardini, A.; Avery, V. M.; Scammells, P. J.; McGowan, S. Two-Pronged Attack: Dual Inhibition of Plasmodium Falciparum M1 and M17 Metalloaminopeptidases by a Novel Series of Hydroxamic Acid-Based Inhibitors. J. Med. Chem. 2014, 57, 9168-9183.

9 France, D. J.; Stepek, G.; Houston, D. R.; Williams, L.; McCormack, G.; Walkinshaw, M. D.; Page, A. P. Identification and Activity of Inhibitors of the Essential Nematode-Specific Metalloprotease Dpy-31. Bioorg. Med. Chem. Lett. 2015, 25, 5752-5755.

10 Novakova, Z.; Wozniak, K.; Jancarik, A.; Rais, R.; Wu, Y.; Pavlicek, J.; Ferraris, D.; Havlinova, B.; Ptacek, J.; Vavra, J.; Hin, N.; Rojas, C.; Majer, P.; Slusher, B. S.; Tsukamoto, T.; Barinka, C. Unprecedented Binding Mode of Hydroxamate-Based Inhibitors of Glutamate Carboxypeptidase Ii: Structural Characterization and Biological Activity. J. Med. Chem. 2016, $59,4539-4550$.

11 Deprez-Poulain, R.; Hennuyer, N.; Bosc, D.; Liang, W. G.; Enée, E.; Marechal, X.; Charton, J.; Totobenazara, J.; Berte, G.; Jahklal, J.; Verdelet, T.; Dumont, J.; Dassonneville, S.; Woitrain, E.; Gauriot, M.; Paquet, C.; Duplan, I.; Hermant, P.; Cantrelle, F.-X.; Sevin, E.; Culot, M.; Landry, V.; Herledan, A.; Piveteau, C.; Lippens, G.; Leroux, F.; Tang, W.-J.; van Endert, P.; Staels, B.; Deprez, B. Catalytic Site Inhibition of Insulin-Degrading Enzyme by a Small Molecule Induces Glucose Intolerance in Mice. Nat. Commun. 2015, 6, 8250.

12 Orbe, J.; Sánchez-Arias, J. A.; Rabal, O.; Rodríguez, J. A.; Salicio, A.; Ugarte, A.; Belzunce, M.; Xu, M.; Wu, W.; Tan, H.; Ma, H.; Páramo, J. A.; Oyarzabal, J. Design, Synthesis, and Biological Evaluation of Novel Matrix Metalloproteinase Inhibitors as Potent Antihemorrhagic Agents: From Hit Identification to an Optimized Lead. J. Med. Chem. 2015, 58, 2465-2488.

13 Noe, M. C.; Natarajan, V.; Snow, S. L.; Mitchell, P. G.; Lopresti-Morrow, L.; Reeves, L. M.; Yocum, S. A.; Carty, T. J.; Barberia, J. A.; Sweeney, F. J.; Liras, J. L.; Vaughn, M.; 
Hardink, J. R.; Hawkins, J. M.; Tokar, C. Discovery of 3,3-Dimethyl-5-Hydroxypipecolic Hydroxamate-Based Inhibitors of Aggrecanase and Mmp-13. Bioorg. Med. Chem. Lett. 2005, 15, 2808-2811.

14 Elbakali, J.; Gras, H.; Maingot, L.; Deprez, B.; Dumont, J.; Leroux, F.; Deprez-Poulain, R. Inhibition of Aggrecanase as a Therapeutic Strategy in Osteoarthritis. Future Med. Chem. 2014, 6, 1399-1412.

15 Zhu, Z.; Mazzola, R.; Sinning, L.; McKittrick, B.; Niu, X.; Lundell, D.; Sun, J.; Orth, P.; Guo, Z.; Madison, V.; Ingram, R.; Beyer, B. M. Discovery of Novel Hydroxamates as Highly Potent Tumor Necrosis Factor-Converting Enzyme Inhibitors: Part I:Discovery of Two Binding Modes. J. Med. Chem. 2008, 51, 725-736.

16 a) Ouvry, G.; Berton, Y.; Bhurruth-Alcor, Y.; Bonnary, L.; Bouix-Peter, C.; Bouquet, K.; Bourotte, M.; Chambon, S.; Comino, C.; Deprez, B.; Duvert, D.; Duvert, G.; Hacini-Rachinel, F.; Harris, C. S.; Luzy, A.-P.; Mathieu, A.; Millois, C.; Pascau, J.; Pinto, A.; Polge, G.; Reitz, A.; Reversé, K.; Rosignoli, C.; Taquet, N.; Hennequin, L. F. Identification of Novel Tace Inhibitors Compatible with Topical Application. Bioorg. Med. Chem. Lett. 2017, 27, 18481853. b) Boiteau, J.-G.; Ouvry, G.; Arlabosse, J.-M.; Astri, S.; Beillard, A.; Bhurruth-Alcor, Y.; Bonnary, L.; Bouix-Peter, C.; Bouquet, K.; Bourotte, M.; Cardinaud, I.; Comino, C.; Deprez, B.; Duvert, D.; Féret, A.; Hacini-Rachinel, F.; Harris, C. S.; Luzy, A.-P.; Mathieu, A.; Millois, C.; Orsini, N.; Pascau, J.; Pinto, A.; Piwnica, D.; Polge, G.; Reitz, A.; Reversé, K.; Rodeville, N.; Rossio, P.; Spiesse, D.; Tabet, S.; Taquet, N.; Tomas, L.; Vial, E.; Hennequin, L. F. Discovery and Process Development of a Novel Tace Inhibitor for the Topical Treatment of Psoriasis. Bioorg. Med. Chem., [Online early access]. doi:10.1016/j.bmc.2017.07.054. Published Online: 2 August 2017. URL (accessed October $\left.5^{\text {th }}, 2017\right)$.

17 Yao, W.; Zhuo, J.; Burns, D. M.; Xu, M.; Zhang, C.; Li, Y. L.; Qian, D. Q.; He, C.; Weng, L.; Shi, E.; Lin, Q.; Agrios, C.; Burn, T. C.; Caulder, E.; Covington, M. B.; Fridman, J. S.; 
Friedman, S.; Katiyar, K.; Hollis, G.; Li, Y.; Liu, C.; Liu, X.; Marando, C. A.; Newton, R.; Pan, M.; Scherle, P.; Taylor, N.; Vaddi, K.; Wasserman, Z. R.; Wynn, R.; Yeleswaram, S.; Jalluri, R.; Bower, M.; Zhou, B. B.; Metcalf, B. Discovery of a Potent, Selective, and Orally Active Human Epidermal Growth Factor Receptor-2 Sheddase Inhibitor for the Treatment of Cancer. J. Med. Chem. 2007, 50, 603-606.

18 Falkenberg, K. J.; Johnstone, R. W. Histone Deacetylases and Their Inhibitors in Cancer, Neurological Diseases and Immune Disorders. Nat. Rev. Drug Discovery 2014, 13, 673-691.

19 Yang, S.-M.; Scannevin, R. H.; Wang, B.; Burke, S. L.; Huang, Z.; Karnachi, P.; Wilson, L. J.; Rhodes, K. J.; Lagu, B.; Murray, W. V. B-N-Biaryl Ether Sulfonamide Hydroxamates as Potent Gelatinase Inhibitors: Part 2. Optimization of A-Amino Substituents. Bioorg. Med. Chem. Lett. 2008, 18, 1140-1145.

20 Du, L.; Musson, D. G.; Wang, A. Q. Stability Studies of Vorinostat and Its Two Metabolites in Human Plasma, Serum and Urine. J. Pharm. Biomed. Anal. 2006, 42, 556-564.

21 Kitamura, S.; Sugihara, K.; Tatsumi, K. Reductase Activity of Aldehyde Oxidase toward the Carcinogen N-Hydroxy-2-Acetylaminofluorene and the Related Hydroxamic Acids. Biochem. Mol. Biol. Int. 1994, 34, 1197-1203.

22 (a) Mulder, G. J.; Meerman, J. H. Sulfation and Glucuronidation as Competing Pathways in the Metabolism of Hydroxamic Acids: The Role of N,O-Sulfonation in Chemical Carcinogenesis of Aromatic Amines. Environ. Health Perspect. 1983, 49, 27-32.; (b) Song, D.; Lee, C.; Kook, Y. J.; Oh, S. J.; Kang, J. S.; Kim, H.-J.; Han, G. Improving Potency and Metabolic Stability by Introducing an Alkenyl Linker to Pyridine-Based Histone Deacetylase Inhibitors for Orally Available Runx3 Modulators. Eur. J. Med. Chem. 2017, 126, 997-1010.. 23 Lassalas, P.; Gay, B.; Lasfargeas, C.; James, M. J.; Tran, V.; Vijayendran, K. G.; Brunden, K. R.; Kozlowski, M. C.; Thomas, C. J.; Smith, A. B., 3rd; Huryn, D. M.; Ballatore, C. Structure Property Relationships of Carboxylic Acid Isosteres. J. Med. Chem. 2016, 59, 3183-3203. 
24 Flipo, M.; Charton, J.; Hocine, A.; Dassonneville, S.; Deprez, B.; Deprez-Poulain, R. Hydroxamates: Relationships between Structure and Plasma Stability. J. Med. Chem. 2009, 52, 6790-6802.

25 Calvo, E.; Reddy, G.; Boni, V.; Garcia-Canamaque, L.; Song, T.; Tjornelund, J.; Choi, M. R.; Allen, L. F. Pharmacokinetics, Metabolism, and Excretion of (14)C-Labeled Belinostat in Patients with Recurrent or Progressive Malignancies. Invest. New Drugs 2016, 34, 193-201.

26 Hajduk, P. J.; Shuker, S. B.; Nettesheim, D. G.; Craig, R.; Augeri, D. J.; Betebenner, D.; Albert, D. H.; Guo, Y.; Meadows, R. P.; Xu, L.; Michaelides, M.; Davidsen, S. K.; Fesik, S. W. Nmr-Based Modification of Matrix Metalloproteinase Inhibitors with Improved Bioavailability. J. Med. Chem. 2002, 45, 5628-5639.

27 Fukami, T.; Yokoi, T. The Emerging Role of Human Esterases. Drug Metab. Pharmacokinet. 2012, 27, 466-477.

28 Casey Laizure, S.; Herring, V.; Hu, Z.; Witbrodt, K.; Parker, R. B. The Role of Human Carboxylesterases in Drug Metabolism: Have We Overlooked Their Importance? Pharmacotherapy 2013, 33, 210-222.

29 Hwang, S.-K.; Juhasz, A.; Yoon, S.-H.; Bodor, N. Soft Drugs. 12. Design, Synthesis, and Evaluation of Soft Bufuralol Analogues. J. Med. Chem. 2000, 43, 1525-1532.

30 Boland, S.; Bourin, A.; Alen, J.; Geraets, J.; Schroeders, P.; Castermans, K.; Kindt, N.; Boumans, N.; Panitti, L.; Fransen, S.; Vanormelingen, J.; Stassen, J. M.; Leysen, D.; Defert, O. Design, Synthesis, and Biological Evaluation of Novel, Highly Active Soft Rock Inhibitors. $J$. Med. Chem. 2015, 58, 4309-4324.

31 Lockridge, O.; Xue, W.; Gaydess, A.; Grigoryan, H.; Ding, S. J.; Schopfer, L. M.; Hinrichs, S. H.; Masson, P. Pseudo-Esterase Activity of Human Albumin: Slow Turnover on Tyrosine 411 and Stable Acetylation of 82 Residues Including 59 Lysines. J. Biol. Chem. 2008, 283, 22582-22590. 
32 Harel, M.; Aharoni, A.; Gaidukov, L.; Brumshtein, B.; Khersonsky, O.; Meged, R.; Dvir, H.; Ravelli, R. B.; McCarthy, A.; Toker, L.; Silman, I.; Sussman, J. L.; Tawfik, D. S. Structure and Evolution of the Serum Paraoxonase Family of Detoxifying and Anti-Atherosclerotic Enzymes. Nat. Struct. Mol. Biol. 2004, 11, 412-419.

33 Montella, I. R.; Schama, R.; Valle, D. The Classification of Esterases: An Important Gene Family Involved in Insecticide Resistance--a Review. Mem. Inst. Oswaldo Cruz 2012, 107, 437449.

34 Yamaori, S.; Fujiyama, N.; Kushihara, M.; Funahashi, T.; Kimura, T.; Yamamoto, I.; Sone, T.; Isobe, M.; Ohshima, T.; Matsumura, K.; Oda, M.; Watanabe, K. Involvement of Human Blood Arylesterases and Liver Microsomal Carboxylesterases in Nafamostat Hydrolysis. Drug Metab. Pharmacokinet. 2006, 21, 147-155.

35 Ronco, C.; Foucault, R.; Gillon, E.; Bohn, P.; Nachon, F.; Jean, L.; Renard, P.-Y. New Huprine Derivatives Functionalized at Position 9 as Highly Potent Acetylcholinesterase Inhibitors. ChemMedChem 2011, 6, 876-888.

36 Imai, T.; Taketani, M.; Shii, M.; Hosokawa, M.; Chiba, K. Substrate Specificity of Carboxylesterase Isozymes and Their Contribution to Hydrolase Activity in Human Liver and Small Intestine. Drug Metab. Dispos. 2006, 34, 1734-1741.

37 Minagawa, T.; Kohno, Y.; Suwa, T.; Tsuji, A. Species Differences in Hydrolysis of Isocarbacyclin Methyl Ester (Tei-9090) by Blood Esterases. Biochem. Pharmacol. 1995, 49, $1361-1365$.

38 Rudakova, E. V.; Boltneva, N. P.; Makhaeva, G. F. Comparative Analysis of Esterase Activities of Human, Mouse, and Rat Blood. Bull. Exp. Biol. Med. 2011, 152, 73-75.

39 Bahar, F. G.; Ohura, K.; Ogihara, T.; Imai, T. Species Difference of Esterase Expression and Hydrolase Activity in Plasma. J. Pharm. Sci. 2012, 101, 3979-3988. 
40 Hosokawa, M. Structure and Catalytic Properties of Carboxylesterase Isozymes Involved in Metabolic Activation of Prodrugs. Molecules 2008, 13, 412-431.

41 Li, B.; Sedlacek, M.; Manoharan, I.; Boopathy, R.; Duysen, E. G.; Masson, P.; Lockridge, O. Butyrylcholinesterase, Paraoxonase, and Albumin Esterase, but Not Carboxylesterase, Are Present in Human Plasma. Biochem. Pharmacol. 2005, 70, 1673-1684.

42 Meshorer, E.; Soreq, H. Virtues and Woes of Ache Alternative Splicing in Stress-Related Neuropathologies. Trends Neurosci. 2006, 29, 216-224.

43 Polasek, T. M.; Doogue, M. P.; Miners, J. O. Metabolic Activation of Clopidogrel: In Vitro Data Provide Conflicting Evidence for the Contributions of Cyp2c19 and Pon1. Ther. Adv. Drug Saf. 2011, 2, 253-261.

44 Eng, H.; Niosi, M.; McDonald, T. S.; Wolford, A.; Chen, Y.; Simila, S. T.; Bauman, J. N.; Warmus, J.; Kalgutkar, A. S. Utility of the Carboxylesterase Inhibitor Bis-ParaNitrophenylphosphate (Bnpp) in the Plasma Unbound Fraction Determination for a Hydrolytically Unstable Amide Derivative and Agonist of the Tgr5 Receptor. Xenobiotica 2010, $40,369-380$.

45 Warmus, J. S.; Quinn, C. L.; Taylor, C.; Murphy, S. T.; Johnson, T. A.; Limberakis, C.; Ortwine, D.; Bronstein, J.; Pagano, P.; Knafels, J. D.; Lightle, S.; Mochalkin, I.; Brideau, R. and Podoll, T. Structure-Based Design of an in vivo Active Hydroxamic Acid Inhibitor of $P$. aeruginosa LpxC. Bioorg. Med. Chem. Lett. 2012, 22, 2536-2543.

46 (a) Cheng, X.-C.; Wang, R.-L.; Dong, Z.-K.; Li, J.; Li, Y.-Y. and Li, R.-R. Design, Synthesis and Evaluation of Novel Metalloproteinase Inhibitors Based on L-Tyrosine Scaffold. Bioorg. Med. Chem. 2012, 20, 5738-5744; (b) Tamura, Y.; Watanabe, F.; Nakatani, T.; Yasui, K.; Fuji, M.; Komurasaki, T.; Tsuzuki, H.; Maekawa, R.; Yoshioka, T.; Kawada, K.; Sugita, K. and Ohtani, M. Highly Selective and Orally Active Inhibitors of Type IV Collagenase (MMP-9 and MMP-2): N-Sulfonylamino Acid Derivatives. J. Med. Chem. 1998, 41, 640-649; (c) Supuran, 
C. T. and Scozzafava, A. Protease inhibitors. Part 7: Inhibition of Clostridium histolyticum Collagenase with Sulfonylated Derivatives of L-Valine Hydroxamate. Eur. J. Pharm. Sci. 2000, 10, 67-76. (d) MacPherson, L. J.; Bayburt, E. K.; Capparelli, M. P.; Carroll, B. J.; Goldstein, R.; Justice, M. R.; Zhu, L.; Hu, S.; Melton, R. A.; Fryer, L.; Goldberg, R. L.; Doughty, J. R.; Spirito, S.; Blancuzzi, V.; Wilson, D.; O'Byrne, E. M.; Ganu, V. and Parker, D. T. Discovery of CGS 27023A, a Non-Peptidic, Potent, and Orally Active Stromelysin Inhibitor That Blocks Cartilage Degradation in Rabbits. J. Med. Chem. 1997, 40, 2525-2532; (e) Dankwardt, S. M.; Abbot, S. C.; Broka, C. A.; Martin, R. L.; Chan, C. S.; Springman, E. B.; Van Wart, H. E. and Walker, K. A. M. Amino Acid Derived Sulfonamide Hydroxamates as Inhibitors of Procollagen C-Proteinase. Part 2: Solid-Phase Optimization of Side Chains. Bioorg. Med. Chem. Lett. 2002, $12,1233-1235$.

47 Elbakali, J.; Gras, H.; Maingot, L.; Deprez, B.; Dumont, J.; Leroux, F.; Deprez-Poulain, R. Inhibition of Aggrecanase as a Therapeutic Strategy in Osteoarthritis. Future Med. Chem. 2014, $6,1399-1412$.

48 Clary, L.; Pascal, j.-C. 4-Alkoxy-N- (2-Hydroxycarbamoyl-2-Piperidinyl-Ethyl) Benzamide Compounds as Selective Tace-Inhibitors for the Treatment of Inflammatory Diseases. WO2011033010 (A1) March 24, 2011.

49 Finn, P. W.; Bandara, M.; Butcher, C.; Finn, A.; Hollinshead, R.; Khan, N.; Law, N.; Murthy, S.; Romero, R.; Watkins, C.; Andrianov, V.; Bokaldere, R. M.; Dikovska, K.; Gailite, V.; Loza, E.; Piskunova, I.; Starchenkov, I.; Vorona, M. and Kalvinsh, I. Novel Sulfonamide Derivatives as Inhibitors of Histone Deacetylase. Helv. Chim. Acta 2005, 88, 1630-1657.

50 Wang, H.; Yu, N.; Chen, D.; Lee, K. C. L.; Lye, P. L.; Chang, J. W. W.; Deng, W.; Ng, M. C. Y.; Lu, T.; Khoo, M. L.; Poulsen, A.; Sangthongpitag, K.; Wu, X.; Hu, C.; Goh, K. C.; Wang, X.; Fang, L.; Goh, K. L.; Khng, H. H.; Goh, S. K.; Yeo, P.; Liu, X.; Bonday, Z.; Wood, J. M.; Dymock, B. W.; Kantharaj, E.; Sun, E. T. Discovery of (2e)-3-\{2-Butyl-1-[2- 
(Diethylamino)Ethyl]-1h-Benzimidazol-5-Y1\}-N-Hydroxyacrylamide (Sb939), an Orally Active Histone Deacetylase Inhibitor with a Superior Preclinical Profile. J. Med. Chem. 2011, $54,4694-4720$.

51 Reiter, L. A.; Robinson, R. P.; McClure, K. F.; Jones, C. S.; Reese, M. R.; Mitchell, P. G.; Otterness, I. G.; Bliven, M. L.; Liras, J.; Cortina, S. R.; Donahue, K. M.; Eskra, J. D.; Griffiths, R. J.; Lame, M. E.; Lopez-Anaya, A.; Martinelli, G. J.; McGahee, S. M.; Yocum, S. A.; Lopresti-Morrow, L. L.; Tobiassen, L. M.; Vaughn-Bowser, M. L. Pyran-Containing Sulfonamide Hydroxamic Acids: Potent Mmp Inhibitors That Spare Mmp-1. Bioorg. Med. Chem. Lett. 2004, 14, 3389-3395.

52 Matter, H.; Schudok, M.; Schwab, W.; Thorwart, W.; Barbier, D.; Billen, G.; Haase, B.; Neises, B.; Weithmann, K.-U.; Wollmann, T. Tetrahydroisoquinoline-3-Carboxylate Based Matrix-Metalloproteinase Inhibitors: Design, Synthesis and Structure-Activity Relationship. Bioorg. Med. Chem. 2002, 10, 3529-3544.

53 Murphy-Benenato, K. E.; Olivier, N.; Choy, A.; Ross, P. L.; Miller, M. D.; Thresher, J.; Gao, N.; Hale, M. R. Synthesis, Structure, and Sar of Tetrahydropyran-Based Lpxc Inhibitors. ACS Med. Chem. Lett. 2014, 5, 1213-1218.

54 Ott, G. R.; Asakawa, N.; Lu, Z.; Liu, R.-Q.; Covington, M. B.; Vaddi, K.; Qian, M.; Newton, R. C.; Christ, D. D.; Traskos, J. M.; Decicco, C. P.; Duan, J. J. W. A,B-Cyclic-B-Benzamido Hydroxamic Acids: Novel Templates for the Design, Synthesis, and Evaluation of Selective Inhibitors of Tnf-A Converting Enzyme (Tace). Bioorg. Med. Chem. Lett. 2008, 18, 694-699. 55 Yang, S.-M.; Lagu, B.; Wilson, L. J. Mild and Efficient Lewis Acid-Promoted Detritylation in the Synthesis of N-Hydroxy Amides: A Concise Synthesis of (-)-Cobactin T. J. Org. Chem. 2007, 72, 8123-8126. 
56 Levy, D. E.; Lapierre, F.; Liang, W.; Ye, W.; Lange, C. W.; Li, X.; Grobelny, D.; Casabonne, M.; Tyrrell, D.; Holme, K.; Nadzan, A.; Galardy, R. E. Matrix Metalloproteinase Inhibitors: A Structure-Activity Study. J. Med. Chem. 1998, 41, 199-223.

57 Ho, C. Y.; Strobel, E.; Ralbovsky, J.; Galemmo, R. A. Improved Solution- and Solid-Phase Preparation of Hydroxamic Acids from Esters. J. Org. Chem. 2005, 70, 4873-4875.

58 Harris, T. L.; Worthington, R. J.; Melander, C. A Facile Synthesis of 1,5-Disubstituted-2Aminoimidazoles: Antibiotic Activity of a First Generation Library. Bioorg. Med. Chem. Lett. 2011, 21, 4516-4519.

59 Boldt, G. E.; Kennedy, J. P.; Janda, K. D. Identification of a Potent Botulinum Neurotoxin a Protease Inhibitor Using in Situ Lead Identification Chemistry. Org. Lett. 2006, 8, 1729-1732. $60 \mathrm{Xu}$, D.; Lu, C.; Chen, W. Palladium-Catalyzed Double Arylations of Terminal Olefins in Acetic Acid. Tetrahedron 2012, 68, 1466-1474.

61 Ramachary, D. B.; Venkaiah, C.; Reddy, Y. V.; Kishor, M. Multi-Catalysis Cascade Reactions Based on the Methoxycarbonylketene Platform: Diversity-Oriented Synthesis of Functionalized Non-Symmetrical Malonates for Agrochemicals and Pharmaceuticals. Org. Biomol. Chem. 2009, 7, 2053-2062.

62 Berry, L. M.; Wollenberg, L.; Zhao, Z. Esterase Activities in the Blood, Liver and Intestine of Several Preclinical Species and Humans. Drug Metab. Lett. 2009, 3, 70-77. 
Table of Contents Graphic

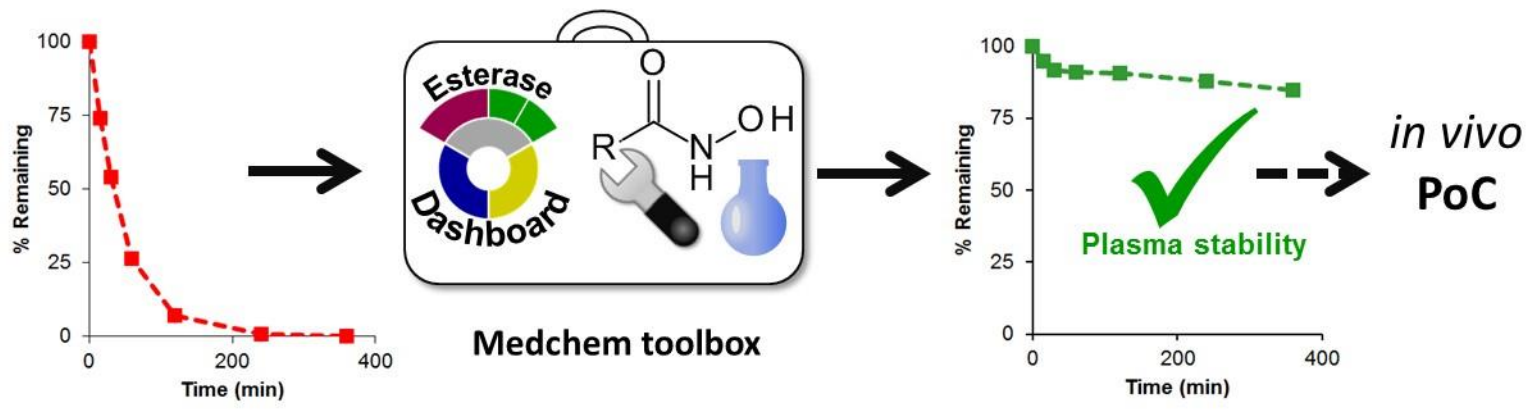

